\title{
Thorium Assessment Study Quarterly Progress Report for Third Quarter Fiscal 1977
}

\author{
I. Spiewak \\ D. E. Bartine
}

\section{MASTR}

\section{OAK RIDGE NATIONAL LABORATORY}




\section{DISCLAIMER}

This report was prepared as an account of work sponsored by an agency of the United States Government. Neither the United States Government nor any agency Thereof, nor any of their employees, makes any warranty, express or implied, or assumes any legal liability or responsibility for the accuracy, completeness, or usefulness of any information, apparatus, product, or process disclosed, or represents that its use would not infringe privately owned rights. Reference herein to any specific commercial product, process, or service by trade name, trademark, manufacturer, or otherwise does not necessarily constitute or imply its endorsement, recommendation, or favoring by the United States Government or any agency thereof. The views and opinions of authors expressed herein do not necessarily state or reflect those of the United States Government or any agency thereof. 


\section{DISCLAIMER}

Portions of this document may be illegible in electronic image products. Images are produced from the best available original document. 
Printed in the United States of America. Available from National Technical Information Service

U.S. Department of Commerce

5285 Port Royal Road, Springfield, Virginia 22161

Price: Printed Copy $\$ 5.25$; Microfiche $\$ 3.00$

This report was prepared as an account of work sponsored by the United States Government. Neither the United States nor any of its employees, nor any of its contractors, subcontractors, or their employees, makes any warranty, express or implied, or assumes any legal liability or responsibility for the accuracy, completeness or usefulness of any information, apparatus, product or process disclosed, or represents that its use would not infringe privately owned rights. 
ORNL/TM-6025

Contract No. W-7405-eng-26

Engineering Technology Division

THORIUM ASSESSMENT STUDY QUARTERLY PROGRESS REPORT

FOR THIRD QUARTER FISCAL 1977

I. Spiewak, Program Director

D. E. Bartine, Program Manager

Contributors :

T. J. Burns

J. C. Cleveland

W. E. Thomas

J. R. White

Manuscript Completed - September 30, 1977

Date Published - October 1977

NOTICE: This document contains information of a preliminary nature. It is subject to revision or correction and therefore does not represent a final report.

Prepared by the OAK RIDGE NATIONAL LABORATORY Oak Ridge, Tennessee 37830 operated by UNION CARBIDE CORPORATION for the DEPARTMENT OF ENERGY

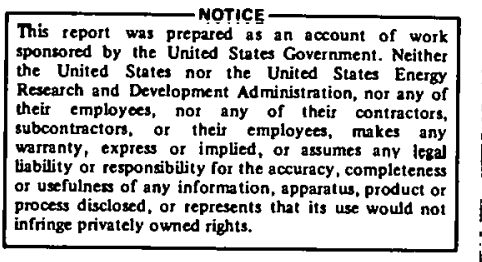

This report was prepared as an account of work sponkored by the United States Covernment. Neither Research and Development Administration, nor any of the warrenty, express or implied, or assumes any lezal or usefulness of any information, apparatus, product or infringe privately owned rights.
intests 


\section{THIS PAGE}

\section{WAS INTENTIONALLY \\ LEFT BLANK}


CONTENTS

Page No.

Abstract...................................... v

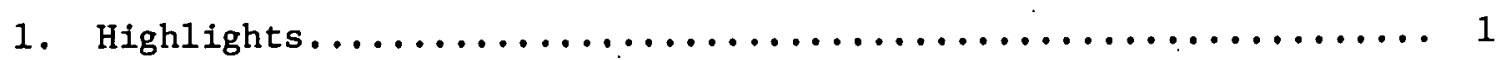

2. Thermal Reactor Calculations...................... 2

2.1 Standard HTGR Reference Design Fuel Cycle Information..... 2

2.2 Mass Balances for a PWR Operating on the Denatured

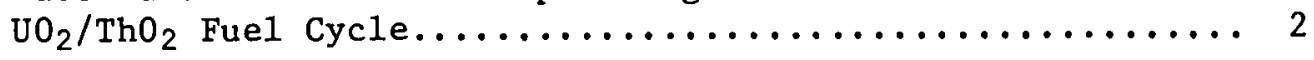

3. Fast Reactor Calculations...................... 8

3.1 Mass Balances for Alternate LMFBR Fuel Cycles........... 8

3.2 Symbiotic Reactor Systems..................... 12

3.3 Cross Section Sensitivity $\ldots \ldots \ldots \ldots \ldots \ldots \ldots \ldots \ldots \ldots \ldots \ldots$

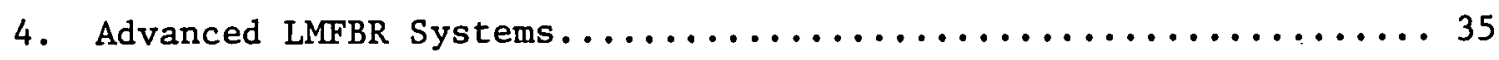

4.1 General Considerations....................... 35

4.2 Thorium Base Metal Fuels.................... 35

4.3 Thorium Base Carbide Fuels.................... 36

5. Flow of Nuclear Material for Restricted Fuel Cycle Scenarios.... 37

References..................................... 48 


\section{THIS PAGE WAS INTENTIONALLY LEFT BLANK}




\begin{abstract}
The objective of this program is to contribute to the ongoing assessment of the potential role of thorium fuel cycles for alleviating safeguards concerns. Scenarios include (1) no fuel recycle permitted, (2) fuel recycle permitted only in secure regions ("energy parks") with denatured (chemically non-separable) fuels only outside these regions, and (3) no limits on fuel recycle. A further objective is to provide nuclear mass balance data on HTGRs required by ERDA contractors for comparative cost-benefit studies.
\end{abstract}




\section{HIGHLIGHTS}

D. E. Bartine

During the third quarter of FY 77 , a normalized summary of mass balance information for thermal reactor fuel cycles was prepared from data supplied by various TAP participants. Mass balances were generated for 8 LMFBR fuel cycles, indicating decreased breeding ratios for the substitution of ${ }^{233} \mathrm{U}$ for $\mathrm{Pu}$ fissile material and for the substitution of ${ }^{232} \mathrm{Th}$ for ${ }^{238} \mathrm{U}$ fertile material. Studies continued on the symbiotic relationship coupling dispersed fast reactors operating on denatured fuel $\left({ }^{233} \mathrm{U} /{ }^{238} \mathrm{U}\right)$ with ${ }^{233} \mathrm{U}$ production reactors operating in centralized energy centers. The existence of an asymptotic outside to inside power ratio for defined symbiotic systems was determined, and a compound system doubling time definition was developed for the combined system. A tradeoff was noted between outside/inside power ratio and doubling time. Cross section sensitivity calculations were performed to determine the effect of estimated uncertainties in the ${ }^{232}$ Th capture cross section on symbiotic system performance, indicating significant lowering of the breeding ratio and sharp increases in the compound system doubling time. These potential losses may be recaptured by reactor designs which are optimized for Th cycle fuels.

A preliminary investlgation of the utilization of Th base metal fuels in LMFBRo indicates a potential role for a $\mathrm{Th} / \mathrm{U} / \mathrm{Pu}$ trinary metal system. 1

A description of the flow of nuclear materials for restricted fuel cycle scenarios was generated, including detailed flow charts. 


\section{THERMAL REACTOR CALCULATIONS}

J. C. Cleveland

W. E. Thomas

\subsection{Standard HTGR Reference Deslgn Fuel Cycle Information}

Thirty years of mass flow data was generated for a Th-HEU HTGR. The reactor design is for a $3000 \mathrm{MW}(t), 1160 \mathrm{MW}(\mathrm{e})$ plant with a core power density of $8.4 \mathrm{w} / \mathrm{cc}$. The carbon to thorfum ratio is 214 for the finiclal core and 238 for reload batches. More detalled core design information is given in ref. 1. The fuel management scheme lnvolves self-generated recycle of the bred uranium with one recycle of the fully enriched makeup uranium. Recycle of uranium bred from thorium continues throughout the history of the reactor. The calculations assumed annual refueling with a constant capacity factor of $80 \%$. With the exception of the linilial core, fuel in each of four approximately equal volume segments remains in the reactor for four cycles. The calculated average conversion ratio for the equilibrium cycle is 0.65 . Mass balance information is provided In Tables 2.1 and 2.2. Information presented here represents a more detailed calculation of mass flows from that presented in ref. 1.

\subsection{Mass Balances for Thermal Reactors}

A summary of mace baldule information for various thermal reactor fuel cycle combinations as determined by various Thorium Assessment Program participants has been prepared and is presented in Table 2.3. The source of the information for each case is given in the last column of the table. Mass balance Information for all cases has been put on the same 
Table 2.1 Mass balance equilibrium discharge information for the $1160 \mathrm{MW}(\mathrm{e})$ standard HTGR

HEAVY MFTAL DISCHARGED (KG)

\begin{tabular}{|c|c|c|c|c|c|c|c|c|c|c|c|c|}
\hline CYCLE & THORIUM & $\begin{array}{l}\text { ARESH } \\
\mathrm{U}-235\end{array}$ & $\begin{array}{l}\text { MAK EUP* } \\
\text { II RANIIIY }\end{array}$ & $\begin{array}{l}* B R E D \\
U-233\end{array}$ & $\begin{array}{r}\text { II RA N I UA } \\
\text { U }-235\end{array}$ & $\begin{array}{l}\text { REMOVED* } \\
\text { IRANIDI }\end{array}$ & $\begin{array}{l}\text { SPENT U U } \\
U-235\end{array}$ & $\begin{array}{l}\text { RETIEED } \\
\text { URANIUA }\end{array}$ & TOTAL U & $\begin{array}{l}\text { BEHOPED } \\
\text { TOTAL. }\end{array}$ & $\begin{array}{l}\text { **PLUT } \\
\text { PISSILE }\end{array}$ & $\begin{array}{r}\text { IOH*** } \\
\text { TOTAL }\end{array}$ \\
\hline 1 & 9906.0 & 221.6 & 294.0 & 149.5 & 0.9 & 161.4 & $\begin{array}{r}2.3 \\
0.0\end{array}$ & 0.0 & 371.9 & 455.5 & $\begin{array}{r}\text { F } 130.8 \\
0.8\end{array}$ & 1018 \\
\hline 2 & 8760.2 & 104.0 & 180.7 & 194.8 & 3.5 & 222.7 & 0.0 & 0.0 & 302.3 & 403.6 & 0.9 & 2.7 \\
\hline 3 & 8590.6 & 56.4 & 135.1 & 223.4 & 7.3 & 269.6 & 0.0 & 0.0 & 287.2 & 404.7 & 1.1 & 4.8 \\
\hline 4 & 8426.7 & 39.5 & 108.1 & 2.37 .6 & 11.6 & 300.7 & 0.0 & 0.0 & 280.8 & 408.7 & 9.4 & 7.2 \\
\hline 5 & 8444.0 & 72.1 & 222.1 & 241.0 & 11.2 & 302.5 & 0.0 & 0.0 & 324.3 & 524.6 & 2.7 & 13.5 \\
\hline 6 & 7623.6 & 32.7 & 95.8 & 227.8 & 15.0 & 301.9 & 21.1 & 100.1 & 296.6 & 497.6 & 2.7 & 14.6 \\
\hline 7 & 7627.4 & 41.3 & 117.2 & 232.2 & 19.7 & 319.0 & 10.5 & 77.1 & 302.7 & 513.2 & 2.8 & 15.1 \\
\hline 8 & 76.29 .1 & 42.3 & 118.3 & 235.0 & 22.2 & 334.2 & 5.9 & 67.6 & 305.4 & 520.1 & 2.7 & 15.0 \\
\hline 9 & 8457.9 & 43.3 & 119.9 & 260.9 & 26.3 & 376.3 & 3.4 & 60.3 & 333.8 & 556.5 & 2.7 & 14.8 \\
\hline 10 & 7632.0 & 39.7 & 108.9 & 237.7 & 25.0 & 346.6 & 7.9 & 121.0 & 310.4 & 576.6 & 3.8 & 21.5 \\
\hline 11 & 7632.1 & 43.4 & 118.9 & 236.5 & 26.5 & 351.1 & 3.5 & 51.4 & 310.0 & 521.4 & 2.4 & 13.5 \\
\hline 12 & 7632.5 & 43.6 & 119.1 & 236.9 & 28.5 & 358.9 & 4.5 & 62.4 & 313.6 & 540.3 & 2.7 & 15.0 \\
\hline 13 & 8460.4 & 44.5 & 121.9 & 261.4 & 31.4 & 396.2 & 4.6 & 62.7 & 342.1 & 580.7 & 2.7 & 15.4 \\
\hline 14 & 76.32 .2 & 34.5 & 94.3 & 230.1 & 33.2 & 379.3 & 4.7 & 63.4 & 311.6 & 536.9 & 2.5 & 14.3 \\
\hline 15 & 76.33 .3 & 41.6 & 112.7 & 233.2 & 31.7 & 372.7 & 4.4 & 57.4 & 315.9 & 542.9 & 2.5 & 14.4 \\
\hline 16 & 7634.1 & 41.9 & 113.2 & 239.5 & 32.4 & 376.1 & 4.8 & 62.7 & 317.6 & 552.0 & 2.7 & 15.3 \\
\hline 17 & 8462.8 & 4.3 .1 & 116.0 & 262.9 & 34.3 & 410.4 & 4.7 & 62.8 & 345.2 & 589.2 & 2.7 & .6 \\
\hline 18 & 7636.0 & 39.4 & 105.2 & 241.2 & 35.6 & 392.3 & 5.1 & 64.4 & 321.3 & 561.8 & 2.6 & 15.5 \\
\hline 19 & 76.36 .3 & 41.9 & 19.7 & 237.6 & 35.5 & 391.7 & 3.7 & 49.8 & 321.0 & 553.3 & 2.4 & 14.3 \\
\hline 20 & 76.36 .8 & 42.1 & 111.9 & 239.8 & 34.8 & 398.7 & 4.8 & 59.6 & 321.4 & 560.2 & 2.6 & 15.3 \\
\hline 21 & 8465.8 & 47.0 & 124.4 & 264.3 & 36.1 & 420.8 & 4.8 & 59.7 & 352.2 & 604.8 & 2.8 & 16.1 \\
\hline 22 & 7639.0 & 37.2 & 99.1 & 242.4 & 37.0 & 401.0 & 5.0 & 61.1 & 321.6 & 560.3 & 2.5 & 15.2 \\
\hline 23 & 7638.7 & 43.1 & 113.3 & 240.9 & 36.7 & 399.8 & 4.6 & 55.3 & 325.4 & 568.4 & 2.6 & .4 \\
\hline 24 & 7639.2 & 43.4 & 113.6 & 241.0 & 36.6 & 400.5 & 4.9 & 58.8 & 325.8 & 572.8 & 2.7 & 16.0 \\
\hline 25 & 9468.2 & 48.3 & 126.1 & 265.4 & .37 .2 & 428.7 & 4.9 & 58.8 & 355.8 & 613.7 & 2.8 & 16.5 \\
\hline 26 & 7640.0 & 37.9 & 99.7 & 243.4 & 37.9 & 407.6 & 5.5 & 65.3 & 324.7 & 571.7 & 2.6 & -1 \\
\hline 27 & 7640.3 & 43.7 & 113.8 & 241.7 & 37.4 & 405.2 & 4.4 & 51.5 & 327.2 & 570.5 & 5 & \\
\hline 28 & 7640.6 & 43.9 & 113.9 & 241.8 & 37.1 & 405.5 & 5.1 & 59.4 & 327.9 & 578.8 & 2.7 & .4 \\
\hline 29 & 8469.8 & 48.7 & 126.5 & 266.3 & 39.1 & 436.2 & 5.2 & 59.5 & 358.4 & 622.2 & 2.9 & 17.2 \\
\hline $3 n$ & 32319.9 & 490.5 & 747.9 & 992.9 & 150.0 & 1653.9 & 53.7 & 293.6 & 1687.2 & 269.5 .3 & 8.1 & 37.0 \\
\hline
\end{tabular}


Table 2.2 Mass balance equi-ibrium charge info:mation for the $1160 \mathrm{MW}$ (e; standard HTGR

GEAVY IETAL CHARGED (KG)

\begin{tabular}{|c|c|c|c|c|c|c|}
\hline & & $\begin{array}{l}\text { * F F ESH } \\
4-275\end{array}$ & PAK EUS & $\begin{array}{l}*=R \\
U-233\end{array}$ & $\begin{array}{c}C L E D \\
U=235\end{array}$ & $\begin{array}{l}\text { ED } \mathrm{J} * * * \\
\text { IRANIUU }\end{array}$ \\
\hline CYCLE & $\begin{array}{l}\text { THORI UT } \\
37482\end{array}$ & $\begin{array}{r}10-235 \\
1701.8\end{array}$ & 1827 .0 & $\begin{array}{r}11-253 \\
0.0\end{array}$ & $\begin{array}{r}U-235 \\
0.0\end{array}$ & "RANIUE \\
\hline & & & & & 0.0 & \\
\hline 2 & 9127.9 & $8: 8,4$ & 867.9 & 0.0 & 0.0 & 0.0 \\
\hline 3 & 8234.7 & 338.4 & 363.3 & 146.4 & 0.9 & 158.2 \\
\hline 4 & 8234.7 & 40.5 .3 & 4.36 .1 & 170.8 & 3.4 & 218.4 \\
\hline 5 & 8234.7 & 406.3 & 436.1 & 218.9 & 7.2 & 264.2 \\
\hline$\epsilon$ & 9127.9 & $4 \div 0.0$ & 440.1 & 232.8 & 11.4 & 294.6 \\
\hline$T$ & 8234.7 & 36.9 .7 & 397.1 & 236.2 & 11.0 & 296.4 \\
\hline 6 & 8234.7 & 403.2 & 432.5 & 223.2 & 14.7 & 295.7 \\
\hline$\underline{0}$ & 8234.7 & 403.2 & 432.8 & 227.6 & 18.3 & 312.6 \\
\hline 10 & 0927.9 & 412.5 & 442.8 & 230.3 & 21.8 & 327.5 \\
\hline $1 \%$ & 8234.7 & 319.5 & 343.0 & 255.5 & 25.7 & 368.7 \\
\hline 12 & 8234.7 & 381.0 & 409.0 & 232.9 & 24.5 & 339.7 \\
\hline 13 & 8234.7 & 381.0 & 4.09 .0 & 231.7 & 26.0 & 344.1 \\
\hline 14 & 9127.9 & 389.6 & ᄂ 18.3 & 232.2 & 27.9 & 351.7 \\
\hline 1.5 & 8234.7 & 351.5 & 377.4 & 256.2 & $30 \ldots 8$ & 388.2 \\
\hline 16 & 8234.7 & 372.8 & 400.2 & 234.3 & $.32 \ldots$ & 371.7 \\
\hline 17 & 8234.7 & 372.8 & 400.2 & 233.4 & 31.1 & $365 . \ddot{2}$ \\
\hline 12 & 9127.9 & 413.2 & 443.6 & $23 ? .7$ & 31.7 & . .5 \\
\hline 17 & 8234.7 & 325.4 & 349.3 & 257.6 & 33.6 & $402 . \bar{c}$ \\
\hline 20 & 8234.7 & 374.8 & 402.3 & 236.3 & 34.9 & 384.4 \\
\hline 21 & 8234.7 & 374.8 & 02.3 & 234.7 & 34.9 & 383.9 \\
\hline 22 & 9127.9 & 415.4 & 446.0 & 234.9 & $34.0^{\circ}$ & .9 \\
\hline 23 & 8234.7 & 324.9 & 348.8 & 259.0 & 35.6 & . \\
\hline 24 & 8234.7 & 37.3 .9 & +01.4 & 237.5 & 36.3 & 393.0 \\
\hline 25 & 8234.7 & 373.9 & +01.4 & 236.1 & 36.0 & 391.8 \\
\hline 26 & ؟. 9127 & 414.4 & $\$ 44.9$ & 236.1 & 35.3 & 392.5 \\
\hline 27 & 8234.7 & 321.9 & 345.6 & 260.1 & 36.5 & 420.2 \\
\hline 28 & 82.34 .7 & 377.3 & 405.0 & 238.5 & 37.1 & .5 \\
\hline 29 & $8234 . ?$ & 177.3 & 405.0 & 235.8 & 36.7 & \\
\hline 30 & 9127.9 & 418.2 & 449.0 & 236.9 & 36.4 & $397 \ldots$ \\
\hline
\end{tabular}

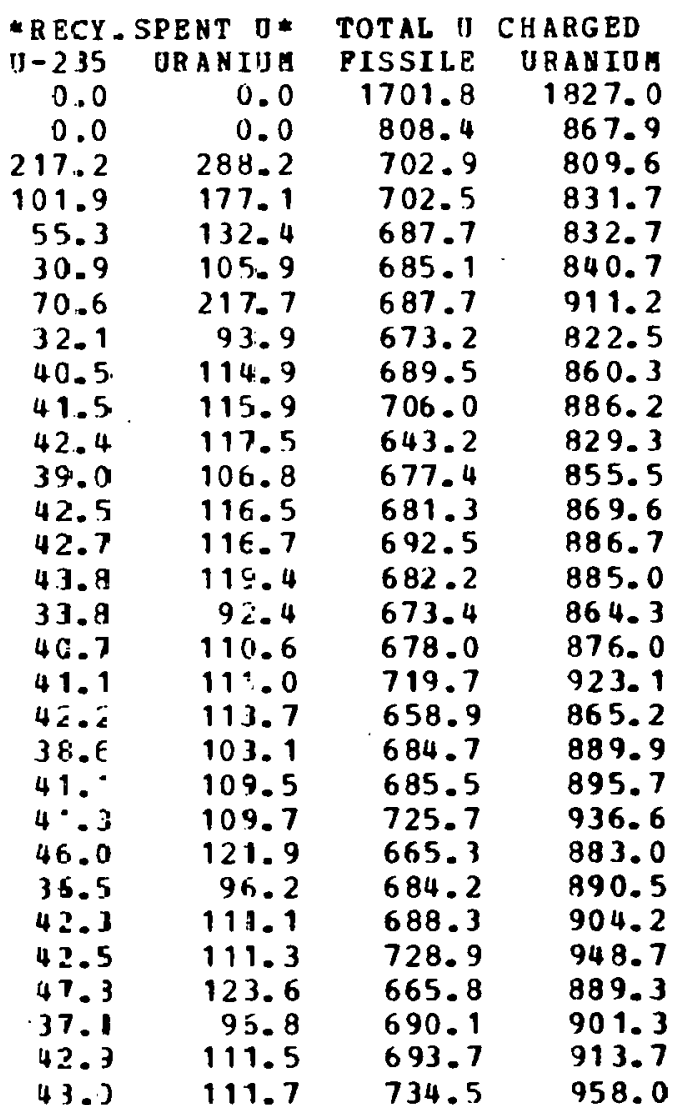


Table 2.3. Summary of mass balance information for various reactor fuel cycle combinations

\begin{tabular}{|c|c|c|c|c|c|c|c|c|c|c|c|c|c|c|c|c|}
\hline $\begin{array}{l}\text { Case } \\
\text { Number }\end{array}$ & Reactor & Cycle & Power & Enrichment $^{\mathrm{a}}$ & $\begin{array}{c}\text { Initial fis- } \\
\text { sile loading } \\
{[\mathrm{kg} \text { (fissilie) }} \\
/ \mathrm{GE}(\mathrm{e})] \mathrm{b}\end{array}$ & $\begin{array}{l}\text { Initial core } \\
\text { fertile mate- } \\
\text { rial loading } \\
\text { [MT/GW(e)yr] }\end{array}$ & $\begin{array}{c}\text { Conver- } \\
\text { sion } \\
\text { ratio } \\
\end{array}$ & $\begin{array}{l}\text { 30. year } \\
\mathrm{ST} / \mathrm{GW}(\mathrm{e})^{\mathrm{b}} \\
\mathrm{U}_{3} \mathrm{O}_{8}\end{array}$ & 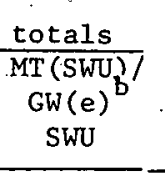 & $\begin{array}{c}\text { Capacity } \\
\text { factor }\end{array}$ & $\begin{array}{l}: \cdot \\
\text { Burnup } \\
\text { (MWD/T) }\end{array}$ & $\begin{array}{l}\text { Fuel reload } \\
\text { scheme }\end{array}$ & $\begin{array}{c}\text { Power } \\
\text { density } \\
(\mathrm{w} / \mathrm{cc})\end{array}$ & $\begin{array}{c}\text { Pu } \\
\text { production } \\
{[\mathrm{kg} / \mathrm{GW}(\mathrm{e}) \mathrm{yr}]^{\mathrm{b}}}\end{array}$ & $\begin{array}{l}\text { Equilibrium annual } \\
\text { makeup requirememts } \\
{[\mathrm{kg} / \mathrm{GW}(\mathrm{e}) \mathrm{yr}]^{\mathrm{b} t \mathrm{~s}}}\end{array}$ & Reference \\
\hline 1 & PWR & $\begin{array}{l}\text { LEU } \\
\text { No recycle }\end{array}$ & $\begin{array}{l}3800 \mathrm{MW}(\mathrm{t}) \\
1300 \mathrm{MN}(\mathrm{e})\end{array}$ & $3.0 \mathrm{w} / \mathrm{o}$ & $1693 \mathrm{U}^{235}$ & $74.3 \mathrm{U}^{238}$ & 0.60 & 5989 & 3555 & 0.75 & 30363 & $\begin{array}{l}1 / 3 \text { of core re- } \\
\text { loaded annually }\end{array}$ & 95.6 & $\begin{array}{l}165 \text { (fissile) } \\
232 \text { (total) }\end{array}$ & $790 \mathrm{~kg} \mathrm{U}^{235}$ & EPRI NP-359 \\
\hline 2 & PWR & $\begin{array}{l}\text { LEU } \\
\text { U recycle } \\
\text { Pu stowaway }\end{array}$ & $\begin{array}{l}3800 \mathrm{MN}(\mathrm{t}) \\
1300 \mathrm{MW}(\mathrm{e})\end{array}$ & & $1693 \mathrm{U}^{235}$ & $74.3 \mathrm{U}^{238}$ & 0.60 & 4946 & 3452 & 0.75 & 30363 & $\begin{array}{l}1 / 3 \text { of core re- } \\
\text { loaded annually. }\end{array}$ & 95.6 & & & EPRI NP-359 \\
\hline 3 & PWR & $\begin{array}{l}\mathrm{LEU} \\
\mathrm{U}+\text { Pu recycle }\end{array}$ & $\begin{array}{l}3800 \mathrm{RW}(\mathrm{t}) \\
1300 \mathrm{MTN}(\mathrm{e})\end{array}$ & $\begin{array}{l}3.6 \text { w/o net } \\
\text { fissile }\end{array}$ & $1693 \mathrm{u}^{235}$ & $74.3 \mathrm{U}^{238}$ & 0.61 & 4089 & 2690 & 0.75 & 30363 & $\begin{array}{l}\text { 1/3 of core re- } \\
\text { loaded annually }\end{array}$ & 95.6 & & $478 \mathrm{~kg} \mathrm{U}^{235}$ & EPRI NPP-359 \\
\hline 4 & $\mathrm{PWR}^{\mathrm{d}}$ & $\begin{array}{l}\text { Th-HEU } \\
\mathrm{U}^{235} \text { makeup } \\
\text { U recycle } \\
\text { Pu stowaway }\end{array}$ & $\begin{array}{l}3800 \mathbb{W W}(t) \\
1300 \mathbb{M N}(e)\end{array}$ & & $2354 \mathrm{U}^{235}$ & $69.4 \mathrm{Th}$ & 0.68 & 3453 & 3436 & 0.75 & 33400 & $\begin{array}{l}1 / 3 \text { of core re- } \\
\text { loaded annually }\end{array}$ & 95.6 & no & $340 \mathrm{~kg} \mathrm{U}^{235}$ & EPRI NP-359 \\
\hline 5. & $\mathrm{PWR}^{\mathrm{d}}$ & $\begin{array}{l}\text { Th-den U } \\
20 \% / 12 \% \\
\mathrm{U}^{235} \text { makeup } \\
\mathrm{U} \text { recycle }\end{array}$ & $\begin{array}{l}3800 \mathrm{MWW}(\mathrm{t}) \\
1300 \mathrm{MW}(\mathrm{e})\end{array}$ & $\begin{array}{l}4.4 \text { w/o makeup } \\
4.2 \text { w/o recycle }\end{array}$ & $2537 \mathrm{v}^{235}$ & $\begin{array}{l}59.3 \mathrm{Th} \\
10.1 \mathrm{U}^{238}\end{array}$ & 0.67 & 4121 & 3940 & $\begin{array}{l}\text { Calculation } \\
\text { performed for } \\
\text { variable } \mathrm{CF}\end{array}$ & $r^{32521}$ & $\begin{array}{l}\text { 1/3 of core re- } \\
\text { loaded annually }\end{array}$ & 95.6 & 76 (fissile) & $421 \mathrm{~kg} \mathrm{U}^{235}$ & $\begin{array}{l}\text { ORNL Quarterly } \\
Q-2,1977 \\
Q-1977\end{array}$ \\
\hline 6 & $\mathrm{PWR}^{\mathrm{f}}$ & $\begin{array}{l}\text { Pu/Th LWR } \\
\text { Pu makeup } \\
\text { Pu recycle }\end{array}$ & $\begin{array}{l}3800 \mathrm{MW}(\mathrm{t}) \\
1300 \mathrm{MW}(\mathrm{e})\end{array}$ & & $\begin{array}{l}2400 \mathrm{~kg} \text { Pu } \\
\text { (fissile) }\end{array}$ & $68.5 \mathrm{Th}$ & $20.63^{\circ}$ & $\mathrm{NA}$ & & 0.75 & 33400 & $\begin{array}{l}1 / 3 \text { of core re- } \\
\text { loaded annually }\end{array}$ & 95.6 & & $\begin{array}{l}\text { véso } \mathrm{kg} P u \\
\text { (fissile) }\end{array}$ & $\begin{array}{l}\text { Letter from R. A. } \\
\text { Iatzie (CE) to J J C. } \\
\text { Cleveland, } 5 / 10 / 77\end{array}$ \\
\hline 7 & $\mathrm{PWR}^{\mathrm{C}}$ & $\begin{array}{l}\text { Th-den U } \\
\mathrm{U}^{235} \text { startup } \\
\mathrm{U}^{233} \text { makeup } \\
\mathrm{U} \text { recycle }\end{array}$ & $\begin{array}{l}3800 \mathrm{MW}(\mathrm{t}) \\
1300 \mathrm{MW}(\mathrm{e})\end{array}$ & & $2537 \mathrm{~kg} \mathrm{v}^{235}$ & $\begin{array}{l}59.3 \mathrm{Th} \\
10.1 \mathrm{U}^{238}\end{array}$ & & NA & & 0.75 & 33400 & $\begin{array}{l}1 / 3 \text { of core re- } \\
\text { loaded annually }\end{array}$ & 95.6 & 67 (fissile) & $290 \mathrm{~kg} \mathrm{U}^{233}$ & $\begin{array}{l}\text { Letter from R. A. } \\
\text { Matzie (CE) to J. C. } \\
\text { Cleveland, 5/10/777 }\end{array}$ \\
\hline 8 & $\mathrm{PVR}^{\mathrm{e}}$ & $\begin{array}{l}\text { Th-den } \mathrm{U}^{233} \\
\mathrm{U}^{233} \text { startup } \\
\mathrm{J}^{233} \text { makeup } \\
\mathrm{U} \text { recycle }\end{array}$ & $\begin{array}{l}3800 \operatorname{Mr}(t) \\
1300 \operatorname{MW}(\mathrm{e})\end{array}$ & & $1840 \mathrm{~kg} \mathrm{v}^{233}$ & $\begin{array}{l}56.5 \mathrm{Th} \\
13.5 \mathrm{U}^{238} \\
.\end{array}$ & & $\mathrm{NA}$ & & 0.75 & 33400 & $\begin{array}{l}1 / 3 \text { of core re- } \\
\text { loaded annually }\end{array}$ & 95.6 & 65 (fissile) & $290 \mathrm{~kg} \mathrm{U} \mathrm{U}^{233}$ & $\begin{array}{l}\text { Letter from R. A. } \\
\text { Matzie (CE) to J C. } \\
\text { Cleveland, } 5 / 10 / 77\end{array}$ \\
\hline 9 & $\mathrm{PWR}^{\mathrm{e}}$ & $\begin{array}{l}\text { Th-den } \mathrm{U}^{233} \\
\mathrm{U}^{233} \text { startup } \\
\mathrm{I}^{233} \text { makerinp } \\
\mathrm{U} \text { recycle }\end{array}$ & $1150 \mathrm{MW}(\mathrm{e})$ & $\begin{array}{l}3.2 \mathrm{w} / \mathrm{o} \text { net } \\
\text { fissile }\end{array}$ & & & & NA & $\mathrm{HA}$ & 0.75 & 33000 & $\begin{array}{l}\text { 1/3 of core re- } \\
\text { loaded annually }\end{array}$ & 95.6 & 60 (fissile) & $294 \mathrm{~kg} \mathrm{U}^{233}$ & $\begin{array}{l}\text { Letter from } \\
\text { Yoon Chang to } \\
\text { K. Danne, } \\
\text { 4/11/77 }\end{array}$ \\
\hline
\end{tabular}


able 2.3 Continued

\begin{tabular}{|c|c|c|c|c|c|c|c|c|c|c|c|c|c|c|c|c|}
\hline $\begin{array}{l}\text { Case } \\
\text { Number }\end{array}$ & Reactor & Cycle & Power & Enrichment $^{\mathrm{a}}$ & $\begin{array}{l}\text { Initial fis- } \\
\text { sile loading } \\
{[\mathrm{kg} \text { (fissile) }} \\
/ \mathrm{GW}(\mathrm{e})]^{\mathrm{b}} \\
\end{array}$ & $\begin{array}{l}\text { Initial core } \\
\text { fertile mate- } \\
\text { rial loading } \\
\text { [MT/GW(e)yr] } \\
\end{array}$ & $\begin{array}{c}\text { Conver- } \\
\text { sion } \\
\text { ratio } \\
\end{array}$ & 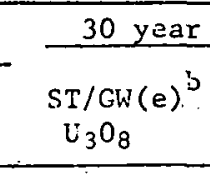 & 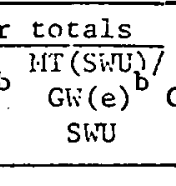 & $\begin{array}{c}\text { Capacity } \\
\text { factor }\end{array}$ & $\begin{array}{l}\text { Burnup } \\
\text { BWW/T }) .\end{array}$ & $\begin{array}{c}\text { Fue1 reload } \\
\text { scheme }\end{array}$ & $\begin{array}{c}\text { Porrer } \\
\text { density } \\
(w / c c)\end{array}$ & $\begin{array}{c}\text { Pu } \\
\text { production } \\
{[\mathrm{kg} / \mathrm{GW}(\mathrm{e}) \mathrm{yr}]^{\mathrm{b}}}\end{array}$ & $\begin{array}{l}\text { Equilibrium annual } \\
\text { makeup requirements } \\
{[\mathrm{kg} / \mathrm{kVI}(\mathrm{e}) \mathrm{yr}]}\end{array}$ & Reference \\
\hline 10 & $\mathrm{CANDU}^{\mathrm{d}}$ & $\begin{array}{l}\text { Th-den U } \\
\mathrm{U}^{2} 35 \text { makeup } \\
\text { Se1f-generated } \\
\text { U recycle }\end{array}$ & $1000 \mathrm{MN}(\mathrm{e})$ & $\begin{array}{l}1.7 \mathrm{w} / \mathrm{o} \text { net } \\
\text { fissile }\end{array}$ & $2121 \cdot \mathrm{U}^{235}$ & & & & & $\begin{array}{l}\text { Calculation } \\
\text { performed for } \\
\text { variable GF }\end{array}$ & 16000 & & & 30 (fissile) & $151 \mathrm{~kg} \mathrm{U}^{235}$ & $\begin{array}{l}\text { ANL Quarterly } \\
\text { Q-1, } 1977\end{array}$ \\
\hline 11 & $\mathrm{CANDU}^{\mathrm{e}}$ & $\begin{array}{l}\text { Th-den } U^{233} \\
U^{233} \text { makeup } \\
U \text { recycle }\end{array}$ & $1000 \mathrm{MWN}(\mathrm{e})$ & $\begin{array}{l}1.6 \mathrm{w} / \mathrm{o} \text { net } \\
\text { f1ssile }\end{array}$ & $1648 \mathrm{U}^{233}$ & & & $\mathrm{NA}$ & NA & $\begin{array}{l}\text { Calculation } \\
\text { performed for } \\
\text { vartabble CF }\end{array}$ & 16000 & & & 32 (fissile) & $102 \mathrm{~kg} \mathrm{U}^{233}$ & $\begin{array}{l}\text { ANL Quarterly } \\
\text { Q-1, } 1977\end{array}$ \\
\hline 12 & CANDU . & $\begin{array}{l}\text { Natural U } \\
\text { No recycle }\end{array}$ & & 0.711 & ? & & 0.74 & $\sim 4600$ & 0.0 & 0.75 & 7500 & $\begin{array}{l}\text { Online } \\
\text { refueling }\end{array}$ & & 323 (fissile) & $851 \mathrm{~kg} \mathrm{U}^{235}$ & $\begin{array}{l}\text { ORNL/TM-5565 } \\
\text { by P. R. Rasten }\end{array}$ \\
\hline 13 & HTER $^{\mathrm{d}-}$ & $\begin{array}{l}\text { Tll1-HEU } \\
\text { II recyc1日 }\end{array}$ & 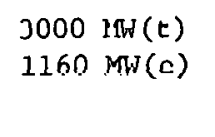 & $\begin{array}{l}7.5 \mathrm{w} / \mathrm{s} \text { net } \\
\text { fissile }\end{array}$ & $1375 \operatorname{lgg} U^{235}$ & $30.3 \mathrm{Th}$ & 0.65 & 2690 & 2684 & $\begin{array}{l}\text { Caiculation } \\
\text { pertiormed at } \\
0.8\end{array}$ & $\begin{array}{l}94000 \\
=\begin{array}{l}\text { for } 0.8 \\
\text { capacity }\end{array}\end{array}$ & $\begin{array}{l}\text { 1/4 of core re- } \\
\text { loaded annually }\end{array}$ & 8.4 & $\begin{array}{l}2.2 \text { (tissile) } \\
12.2(\text { total })\end{array}$ & $300 \mathrm{~kg} \mathrm{U}^{235}$ & $\begin{array}{l}\text { ORNL Quarteily } \\
R^{-1}, 1977\end{array}$ \\
\hline 14 & HTGR $^{\mathrm{d}}$ & $\begin{array}{l}\text { Th-HEU } \\
\mathrm{U}^{235} \text { makeupp } \\
\text { U recycle }\end{array}$ & $\begin{array}{l}4000 \mathrm{MW}(\mathrm{t}) \\
1600 \mathrm{MW}(\mathrm{e})\end{array}$ & $\begin{array}{l}4.1 \text { w/o net } \\
\text { fissile }\end{array}$ & $2772 \mathrm{~kg} \mathrm{U}^{235}$ & $63.4 \mathrm{Th}$ & 0.83 & 2076 & 2073 & $\begin{array}{l}\text { Calculation } \\
\text { porformod at } \\
0.8\end{array}$ & $=\begin{array}{l}41000 \\
=\begin{array}{l}\text { for } 0.8 \\
\text { capacity }\end{array}\end{array}$ & $\begin{array}{l}1 / 4 \text { of core re- } \\
\text { logded anmial1yr }\end{array}$ & 7.0 & $\begin{array}{l}1.1 \text { (fissile) } \\
3.5(\text { trnt.a.1.) }\end{array}$ & $155^{\circ} \mathrm{kg} \mathrm{U}^{235}$ & $\begin{array}{l}\text { Letter from Dick } \\
\text { Lane (GA) to P. P. R. } \\
\text { Kasten, 2/18/77 }\end{array}$ \\
\hline 15 & HTGR ${ }^{e}$ & $\begin{array}{l}\text { Th- } \mathrm{U}^{233} \\
\mathrm{U}^{23} 3 \text { makeup }\end{array}$ & $\begin{array}{l}4000 \mathrm{NW}(\mathrm{t}) \\
1600 \mathrm{MW}(\mathrm{e})\end{array}$ & $\begin{array}{l}3.4 \text { w/u net } \\
\text { fissile }\end{array}$ & $\begin{array}{l}2615 \mathrm{~kg} \mathrm{U}^{733} \\
260 \mathrm{~kg} \mathrm{U}^{235}\end{array}$ & $96.9 \mathrm{Th}$ & $\sim 0.93$ & $\mathrm{NA}$ & & $\begin{array}{l}\text { Calculation } \\
\text { performed at } \\
0.8\end{array}$ & $\begin{array}{l}27000 \\
=\begin{array}{l}\text { for } 0.8 \\
\text { capacity }\end{array}\end{array}$ & $\begin{array}{l}1 / 4 \text { of core re- } \\
\text { loaded annually }\end{array}$ & 5.0 & ขo & $\begin{array}{l}82 \mathrm{lgg} \mathrm{U}^{233} \\
8 \mathrm{~kg} \mathrm{U}^{235}\end{array}$ & $\begin{array}{l}\text { Letter from Dick } \\
\text { Lane (GA) to P. P. R. } \\
\text { Kasten, 2/18/77 R. }\end{array}$ \\
\hline 16 & HTGR & $\begin{array}{l}\text { ĹEU } \\
\text { Nu recycle }\end{array}$ & $\begin{array}{l}3000 \mathrm{MW}(t) \\
1160 \mathrm{MN}(\mathrm{c})\end{array}$ & $\begin{array}{l}\text { 11 w/o nèt } \\
\text { fissile }\end{array}$ & $956 \mathrm{~kg} \mathrm{u}^{235}$ & $10.9 \mathrm{Th}$ & & 5100 & 4235 & $\begin{array}{l}\text { Calculation } \\
\text { performed at } \\
0.8\end{array}$ & $\begin{array}{l}119300 \\
\text { for } 0.8 \\
\text { capiuitity }\end{array}$ & $\begin{array}{l}1 / 3 \text { of core re- } \\
\text { loaded annually }\end{array}$ & 8.4 & $\begin{array}{l}55 \text { (fissile) } \\
100(\text { total })\end{array}$ & $652 \mathrm{~kg} \mathrm{U}^{235}$ & $\begin{array}{l}\text { Letter trom Uick } \\
\text { Lane (GA) to P. R. } \\
\text { Kasten, 2/18/77 }\end{array}$ \\
\hline 17 & SSCR & $\begin{array}{l}\text { LEU } \\
\text { Non recycle }\end{array}$ & $\begin{array}{l}3800 \mathrm{MWN}(\mathrm{t}) \\
1300 \mathrm{MW}(\mathrm{e})\end{array}$ & $2.6 \mathrm{w} / 0$ & $1600 \mathrm{~kg}{ }^{12235}$ & & & 5000 & & 0.75 & 30363 & $\begin{array}{l}1 / 3 \text { of core re- } \\
\text { loaded annually }\end{array}$ & 95.6 & 206 (rissile) & $677 \mathrm{~kg} \mathrm{U}^{23.5}$ & $\begin{array}{l}\text { Lctter from R. A. } \\
\text { Matzie (CE) to J. C. } \\
\text { Cleveland. S/LU/ll }\end{array}$ \\
\hline 18 & SSCR & $\begin{array}{l}\text { Th HEU } \\
\text { U recycle }\end{array}$ & $\begin{array}{l}3800 \mathrm{MW}(\mathrm{t}) \\
1300 \mathrm{MW}(\mathrm{e})\end{array}$ & & $2100 \mathrm{~kg} \mathrm{U}^{235}$ & & & 2200 & & 0.75 & 33400 & $\begin{array}{l}1 / 3 \text { of core re- } \\
\text { loaded annually }\end{array}$ & 95.6 & & $165 \mathrm{~kg} \mathrm{U}^{235}$ & $\begin{array}{l}\text { Letter from R. A. } \\
\text { Matzie (CE) to J. C. } \\
\text { cleveland, } 5 / 10 / 77\end{array}$ \\
\hline 19 & SSCR & $\begin{array}{l}\text { Th-HEU } \\
\text { v recycle }\end{array}$ & $\begin{array}{l}3800 \mathrm{MW}(\mathrm{t}) \\
1300 \mathrm{MW}(\mathrm{e})\end{array}$ & & & & & 2200 & & 0.75 & & $\begin{array}{l}\text { 1/3 nf nnre re- } \\
\text { loaded annually }\end{array}$ & & & & $\begin{array}{l}\text { CE Quarterly } \\
\text { Q-1, } 1977\end{array}$ \\
\hline 20 & SSCR & $\begin{array}{l}\text { Th-den U } \\
\text { U Lecyule }\end{array}$ & $\begin{array}{l}3800 \mathrm{MW}(\mathrm{t}) \\
1300 \mathrm{~kW}(\mathrm{e})\end{array}$ & & & & & 2500 & & 0.75 & & $\begin{array}{l}1 / 3 \text { of core re- } \\
\text { loaded annuallly }\end{array}$ & & & & $\begin{array}{l}\text { CE Quarterly } \\
\text { Q-1, } 1977\end{array}$ \\
\hline 21 & SSCR & $\begin{array}{l}\text { LEU } \\
\text { No recycle }\end{array}$ & $\begin{array}{l}3800 \mathrm{MW}(\mathrm{t}) \\
1300 \mathrm{MW}(\mathrm{e})\end{array}$ & & & & & 5000 & & 0.75 & & $\begin{array}{l}1 / 3 \text { of core re- } \\
\text { loaded annually }\end{array}$ & & & & $\begin{array}{l}\text { CE Quarterly.y } \\
Q-1,1977\end{array}$ \\
\hline
\end{tabular}

${ }^{a}$ Equilibrium requirement, for given reactor power and capacity factor.

${ }^{b}$ At $75 \%$ capacity factor.

${ }^{C}$ At full power.

$\mathrm{d}_{\text {Assumes no exogenous }}{ }^{23{ }^{3} \mathrm{U}}$ source.

$e_{\text {Assumes exogenous }}{ }^{233} \mathrm{U}$ source.

$\mathrm{f}_{\text {Equilibrium annual }} 233_{\mathrm{U}}$ production $\doteq 265 \mathrm{~kg} / \mathrm{GW}(\mathrm{e})$ at $75 \%$ capacity factor. 
basis of a $1000 \mathrm{MW}(\mathrm{e})$ plant operating at $75 \%$ capacity. Since the original calculations were performed for plants of various electrical ratings and assumed capacity factors, the normalization to the same basis required an adjustment of the original data. For this reason the information in the table should be considered approximate.

Cases 4 and 13 are directly comparable cases for Th-HEU fuel in PWRs and HTGRs respectively. Four reasons have been identified for the lower initial core fissile inventory in the HTGR case by comparing results from ORNL calculations for a Th-HEU PWR with results from the ORNL calculations given in case 13 . They are

1. the thermal efficiency of .34 for the PWR compared to .39 for the HTGR, 2. parasitic neutron absorption of $\sim 6.4 \%$ in the PWR clad and coolant vs 1.6\% in the HTGR particle coatings, moderator and coolant,

3. reduced core leakage in the HTGR due to its larger volume which is y 10 times that of the PWR, and

4. reduced $2{ }^{3}{ }^{3} \mathrm{~Pa}$ burnout in the HTGR due to the lower flux levels in the HTGR.

The increased fissile requirement in HTGRs for a higher conversion ratio system is evident by comparing cases 13 and 14 . To achieve the higher conversion ratio HTGR the thorium loading is increased.

This table will be expanded as more information is received from the various ERDA contractors. 


\section{FAST REACTOR CALCULATIONS}

T. J. Burns

J. R. White

\subsection{Mass Balances for Alternate LMFBR Fuel Cycles}

Mass balances (initial loading through equilibrium cycle) have been generated for eight LMFBR fissile/fertile combinations. The following cases are included:

\begin{tabular}{|c|c|c|}
\hline Jaoc & $\begin{array}{l}\text { Core/Axial Blanket/ } \\
\text { Radial Blanket }\end{array}$ & Comments \\
\hline 1 . & $\left(\mathrm{Pu}-{ }^{238} \mathrm{U}^{\circ} \mathrm{O}_{2} /{ }^{238} \mathrm{UO}_{2} / 2{ }^{38} \mathrm{UO}_{2}\right.$ & run as a reference case \\
\hline 2. & $\left({ }^{233} \mathrm{U}^{238} \mathrm{U}\right) \mathrm{O}_{2} /{ }^{238} \mathrm{UO}_{2} / \mathrm{ThO}_{2}$ & $12 \%$ denatured U core assemblies \\
\hline 3. & $\left({ }^{2}{ }^{3}{ }^{\mathrm{U}}-2{ }^{38} \mathrm{U}\right) \mathrm{O}_{2} / \mathrm{ThO}_{2} / \mathrm{ThO}_{2}$ & $12 \%$ denatured $\mathrm{U}$ core assemblies \\
\hline 4 . & $\left({ }^{2}{ }^{3} \mathrm{U}-238 \mathrm{U}-\mathrm{Th}\right) \mathrm{O}_{2} / \mathrm{ThO}_{2} / \mathrm{ThO}_{2}$ & $20 \%$ denatured $U$ in core assembilies \\
\hline 5. & $\left(233_{\mathrm{U}}=238 \mathrm{U}-\mathrm{Th}\right) \cap_{\mathrm{g}} / \mathrm{Th} n_{\mathrm{I}} / \mathrm{Th} n_{3}$ & $4,0 \%$ denatured If in core assemblies \\
\hline 6. & $(\mathrm{Pu}-\mathrm{Th}) \mathrm{O}_{2} / \mathrm{ThO}_{2} / \mathrm{ThO}_{2}$ & possible energy center ${ }^{23} \mathrm{U}$ source \\
\hline 7. & $(\mathrm{Pu}-238 \mathrm{U}) \mathrm{O}_{2} /{ }^{238} \mathrm{UO}_{2} / \mathrm{ThO}_{2}$ & pussible energy Eenter ${ }^{233} \mathrm{U}$ source \\
\hline 8. & $\left(2{ }^{3}{ }^{3} \mathrm{U}-\mathrm{Th}\right) \mathrm{O}_{2} / \mathrm{ThO}_{2} / \mathrm{ThO}_{2}$ & possible energy center ${ }^{2}{ }^{3}{ }^{3} \mathrm{u}$ source \\
\hline
\end{tabular}

The reactor model utilized evolved from that proposed by the Large Core Code Evaluation Working Group. ${ }^{2}$ Although the model does not correspond to a particular commercial design, it is felt to be "representative" of a large core commercial LMH'BK. An axial blanker (at the same uxlde deusily as the core) was added since the original model consisted only of the reactor midplane. Table 3.1 summarizes some of the relevant design parameters of the model. Mass balances for each reactor were calculated by replacing the $\mathrm{PuO}_{2} / 238 \mathrm{UO}_{2}$ fuel of the reference case with the fissile/ fertile combination under consideration (and in some cases replacement 
Table 3.1.. LMFBR des1gn basis

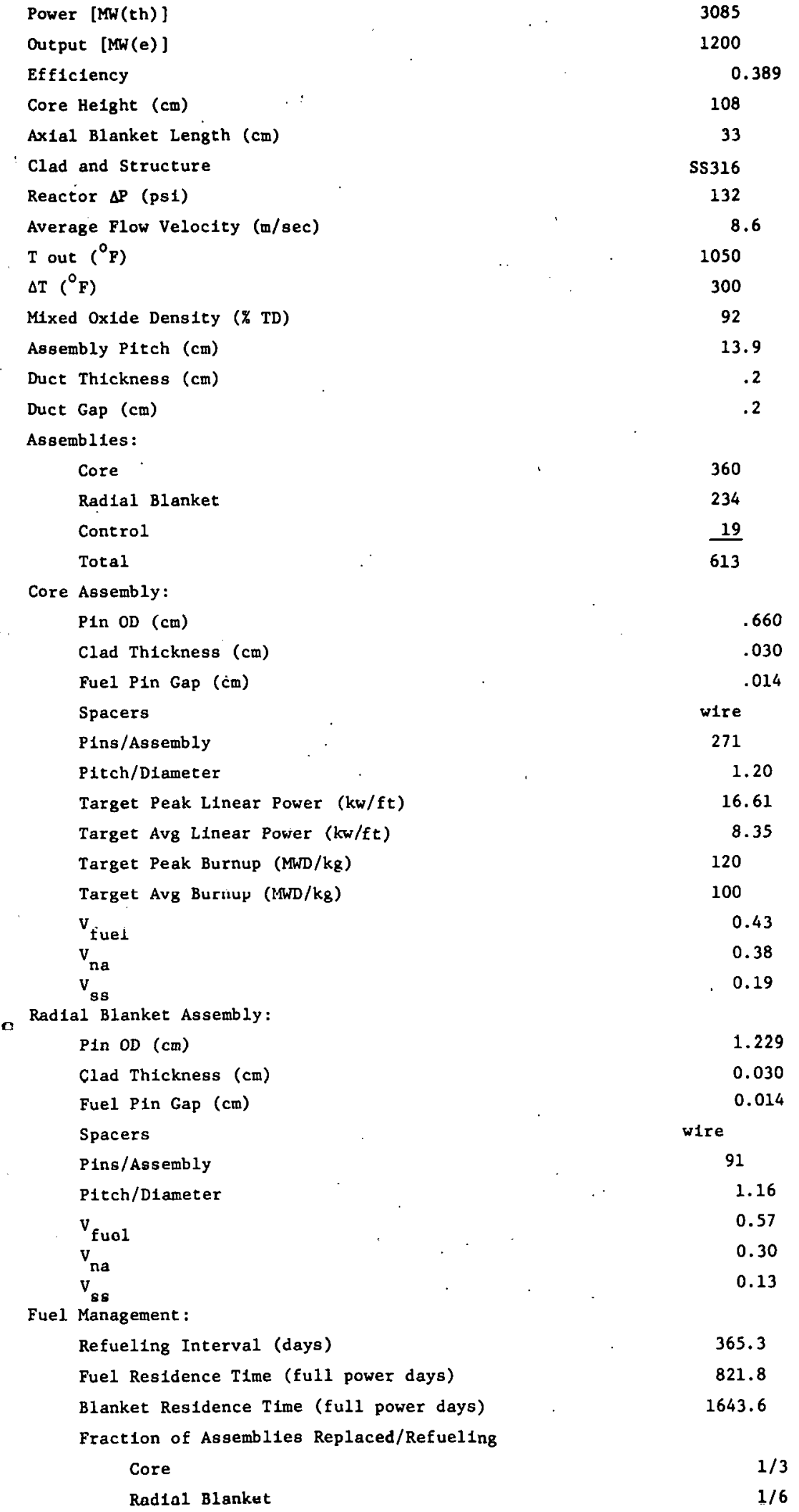


of the depleted $\mathrm{UO}_{2}$ blanket material with $\mathrm{ThO}_{2}$ ). The original heavy metal volume fraction was maintained for all the reactors, the only correction being for the reduced density of $\mathrm{ThO}_{2}$. (Hence, the calculations do not address the possibility of modifying the fuel elements to account for the higher melting point and thermal conductivity of $\mathrm{ThO}_{2}$ relative to $\mathrm{UO}_{2} \cdot$ ) For all calculations, a fuel management scheme which replaced $1 / 3$ of each core zone and $1 / 6$ of the radial blanket each year was employed. A capacity factor of 0.75 was assumed.

The results of these calculations are summarized in Table 3.2. Cases 2 and 3 are distinguished only by different axial blankets. In case 2 the axial blanket extension of the core fuel contains only $\mathrm{Pu}$ and $\mathrm{U}$ isotopes at discharge as does the core region. In case 3 the axial blanket also oontaino Th.

Certain characteristics of the denatured reactors are evident from Table 3.2. The decreased breeding ratios of the denatured reactors reflect two primary effects: the substitution of $233 \mathrm{U}$ for fissile $\mathrm{Pu}$ and corresponding reduction in the average number of neutrons produced per fission, and a reduction in the number of fertile nuclei fissions (due to the significantly smaller fission cross section of ${ }^{232} \mathrm{Th}$ relative to ${ }^{238} \mathrm{U}$ ). One especially noteworthy feature of the denatured reactors is the marked reduction in the amount of fissile $\mathrm{Pu}$ discharged per cycle compared to that of the reference system. Additionally, the ${ }^{23} \mathrm{U}$-fueled systems typically require a smaller fissile inventory than does the corresponding Pu-fueled system (over and above the $\sim 2.5 \%$ correction for different atomic weights of the nuclides).

Cases 6,7 , and 8 represent possible ${ }^{233} \mathrm{U}$ sources. Since ${ }^{23} \mathrm{U}$ is not a naturally occurring isotope, it must be "manufactured" from ${ }^{232} \mathrm{Th}$. 
Table 3.2. Equilibrium cycle summary for alternate LMFBR fuel cycles

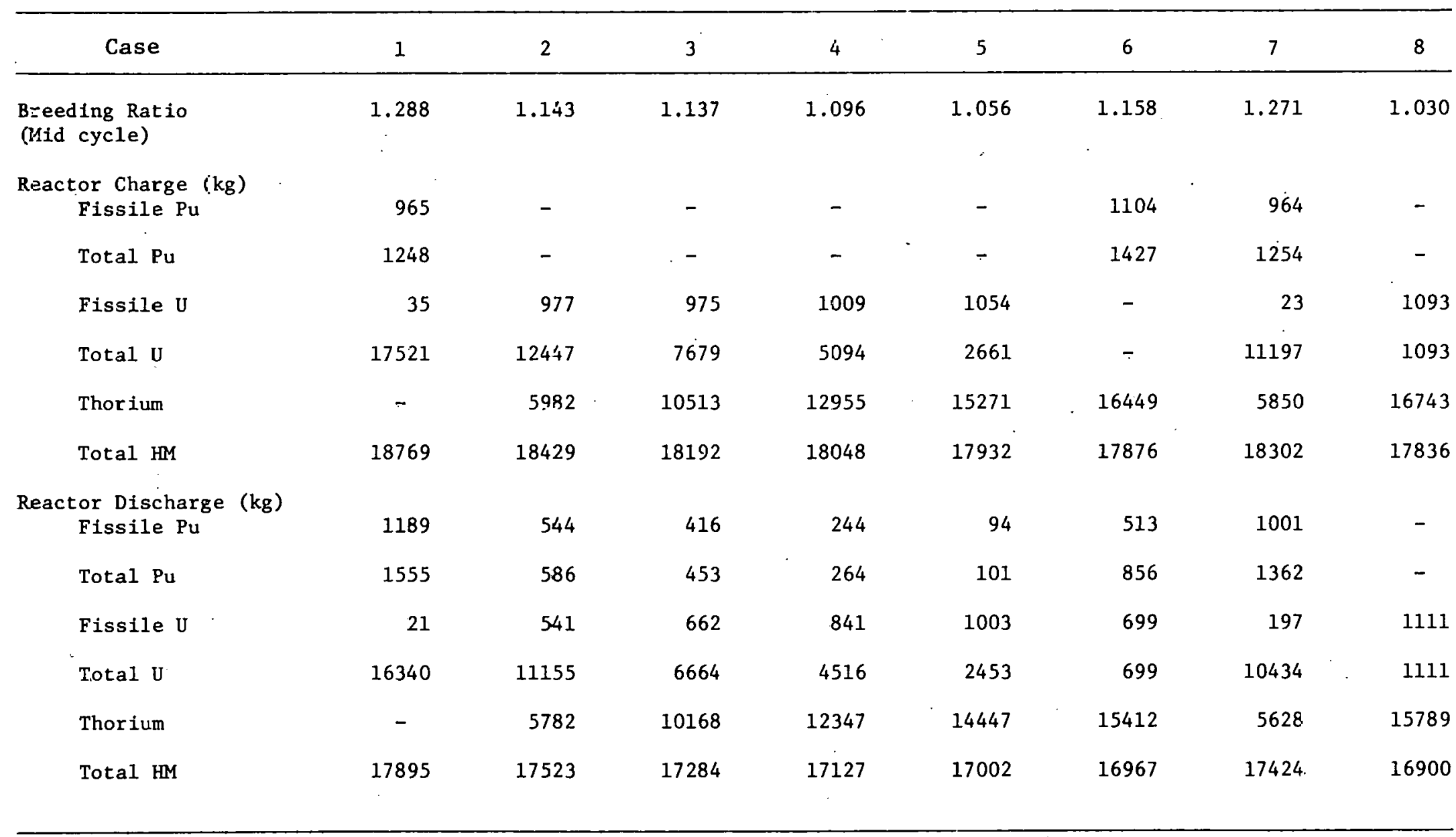


Three possible means of generating a ${ }^{233} \mathrm{U}$ inventory have been considered: a $\mathrm{Pu} / \mathrm{Th}$ LMFBR, the reference $\mathrm{Pu} /{ }^{238} \mathrm{U}$ system with a $\mathrm{ThO}_{2}$ radial blanket, and a ${ }^{233} \mathrm{U} / \mathrm{Th}$ LMFBR. (These reactors must operate within a secure energy center since they are not denatured.) In particular, comparing the reference case with the data for the Pu/Th LMFBR indicates the breeding ratio penalty associated with the fast fission cross section of ${ }^{232}$ Th relative to ${ }^{238} \mathrm{U}$. Tables $3.3-3.18$ tabulate the 30 year mass balances for each reactor adjusted for a variable capacity factor. ${ }^{3}$

\subsection{Symb1ot1c Reàctor Systems}

As indicated by Table 3.2 , the four denatured reactors considered (cases 2-5) are net ${ }^{23} \mathrm{U}$ consumers. Although the overall breeding ratio in each case is greater than 1 , a portion of the bred fissile material (i.e., the Pu bred from the denaturant ${ }^{238} \mathrm{U}$ ) cannot be recycled back into the denatured reactors. This effect is lllustrated by F1g. 3.1 which schematically depicts the isotopic components of the overall breeding ratio. All the denatured reactors considered require a ${ }^{23} \mathrm{U}$ source for makeup requirements (in addition to the initial ${ }^{23}{ }^{3} \mathrm{U}$ inventory required for startup). A symbiotic system is therefore envisioned which would couple the dispersed denatured reactors to a centralized energy center ${ }^{23}{ }^{3} \mathrm{U}$ production reactor. ${ }^{4}$ Figure 3.2 indicates the relative fissile production/destruction rates for the three possibie energy center reactors considered. From the viewpoint of overall fissile production, the $\mathrm{Pu} /{ }^{238} \mathrm{U}$ system with a $\mathrm{ThO}_{2}$ radial blanket is clearly superinr. However, from the standpoint of ${ }^{23} 3 \mathrm{U}$ production, the Pu/Th LMFBR has a distinct advantage. One symbiotic parameter of particular importance is the ratio of power produced in the dispersed reactors to that produced in the energy 
Table 3.3

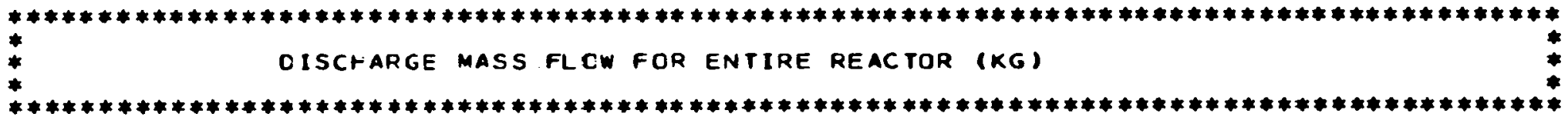

REACTOR IDENTIFICATION: PU-U/U LMFBR O 1200 MWE (RZ MODEL)

PU/UO2 CORE, UO? AXIAL AND RADIAL BLANKETS

(2 CORE ZONES)

\begin{tabular}{|c|c|c|c|c|c|}
\hline $\begin{array}{c}\text { YEAR } \\
1 \\
2 \\
3 \\
4 \\
5 \\
6 \\
7 \\
8 \\
9 \\
10 \\
11 \\
12 \\
13 \\
14 \\
15 \\
16 \\
17 \\
18 \\
19 \\
20 \\
21 \\
22 \\
23 \\
24 \\
25 \\
26 \\
27 \\
25 \\
29 \\
30\end{array}$ & $\begin{array}{l}\text { CAPACITY } \\
\text { FACTOR } \\
0.6000 \\
0.6600 \\
0.7200 \\
0.7200 \\
0.7200 \\
0.7200 \\
0.7200 \\
0.7200 \\
0.7200 \\
0.7200 \\
0.7200 \\
0.7200 \\
0.7200 \\
0.7200 \\
0.7200 \\
0.7200 \\
0.7200 \\
0.7040 \\
0.6890 \\
0.6730 \\
0.6570 \\
0.6410 \\
0.6260 \\
0.6100 \\
0.5940 \\
0.5790 \\
0.5630 \\
0.5470 \\
0.5310 \\
0.5160 \\
0.5000\end{array}$ & $\begin{array}{r}T H 232 \\
0.0 \\
0.0 \\
0.0 \\
0.0 \\
0.0 \\
0.0 \\
0.0 \\
0.0 \\
0.0 \\
0.0 \\
0.0 \\
0.0 \\
0.0 \\
0.0 \\
0.0 \\
0.0 \\
0.0 \\
0.0 \\
0.0 \\
0.0 \\
0.0 \\
0.0 \\
0.0 \\
0.0 \\
0.0 \\
0.0 \\
0.0 \\
0.0 \\
0.0 \\
0.0\end{array}$ & 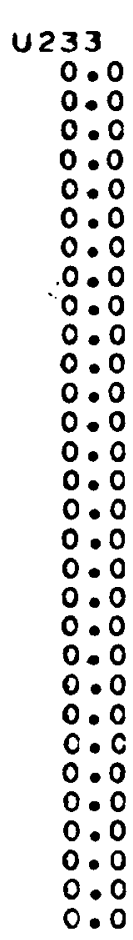 & $\begin{array}{r}4235 \\
24 \cdot 1 \\
22 \cdot 7 \\
21.6 \\
21.1 \\
20.6 \\
20.1 \\
20.1 \\
20.1 \\
20.1 \\
20.1 \\
20.1 \\
20.1 \\
20.1 \\
20.1 \\
20.1 \\
20.1 \\
19.7 \\
19.2 \\
18.8 \\
18.3 \\
17.9 \\
17.5 \\
17.0 \\
16.6 \\
16.2 \\
15.7 \\
15.3 \\
14.8 \\
14.4 \\
71.3\end{array}$ & $\begin{array}{l}\text { U238 } \\
13822.8 \\
14751.4 \\
15787.1 \\
15732.7 \\
15699.9 \\
15668.5 \\
15669.3 \\
15668.2 \\
15666.8 \\
15666.2 \\
15665.9 \\
15665.9 \\
15665.9 \\
15665.9 \\
15665.9 \\
15665.9 \\
15317.7 \\
14991.4 \\
14643.2 \\
14295.1 \\
13947.0 \\
13620.6 \\
13272.5 \\
12924.3 \\
12598.0 \\
12249.8 \\
11901.7 \\
11553.6 \\
11227.2 \\
45727.1\end{array}$ \\
\hline
\end{tabular}

$P \cup 239$
666.9
859.3
982.0
1018.7
1046.2
1071.6
1071.8
1072.8
1073.7
1074.2
1074.3
1074.4
1074.4
1074.4
1074.4
1074.4
1050.5
1078.1
1004.2
980.4
956.5
934.1
910.2
886.4
864.0
840.1
816.2
772.4
770.0
2274.7

PU240
$185 \cdot 3$
$257 \cdot 1$
$297 \cdot 9$
$304 \cdot 8$
$306 \cdot 5$
$308 \cdot 4$
$308 \cdot 3$
$308 \cdot 3$
$308 \cdot 4$
$308 \cdot 4$
$308 \cdot 4$
$308 \cdot 4$
$308 \cdot 4$
$308 \cdot 4$
$308 \cdot 4$
$308 \cdot 4$
$301 \cdot 6$
$295 \cdot 2$
$288 \cdot 3$
$281 \cdot 5$
$274 \cdot 6$
$268 \cdot 2$
$261 \cdot 3$
$254 \cdot 5$
$248 \cdot 0$
$241 \cdot 2$
$234 \cdot 3$
$227 \cdot 5$
$221 \cdot 0$
$594 \cdot 8$

.

9241
$66 \cdot 9$
$70 \cdot 0$
$65 \cdot 2$
$67 \cdot 2$
$67 \cdot 3$
$67 \cdot 4$
$67 \cdot 5$
$67 \cdot 5$
$67 \cdot 5$
$67 \cdot 5$
$67 \cdot 5$
$67 \cdot 5$
$67 \cdot 5$
$67 \cdot 5$
$67 \cdot 5$
$67 \cdot 5$
$66 \cdot 0$
$64 \cdot 6$
$63 \cdot 1$
$61 \cdot 6$
$60 \cdot 1$
$58 \cdot 7$
$57 \cdot 2$
$55 \cdot 7$
$54 \cdot 3$
$52 \cdot 8$
$51 \cdot 3$
$49 \cdot 8$
$48 \cdot 4$
166.5
6

Pu2 42
30.6
39.3
41.5
42.6
42.7
42.7
42.7
42.7
42.7
42.7
42.7
42.7
42.7
42.7
42.7
42.7
41.7
40.8
39.9
38.9
38.0
37.1
36.1
35.2
34.3
33.4
32.4
31.5
30.6
89.3

FISSILE

733.7

$733 \cdot 7$
$929 \cdot 3$
$047 \cdot 2$

1047.2

1085.8

1113.5

1139.3

1140.2

$1141 \cdot 2$

1141.7

1141.8

1141.9

1141.9

1141.9

1141.9

1116.5

1092.7

1067.3

1042.0

1016.6

967.4

942.0

918.2

892.9

867.5

842.1

818.3

166.5

80.3

2441.2

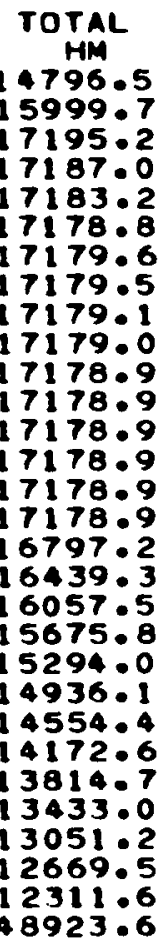


Tajle 3.4

$\star$

*

CHARGE MASS FLOW FJR ENT:RE REACTOR (KG)

REACTOR IDENTIFICATICN: FU-U/U LMFBR a 1200 MWE (RZ MODEL)

PU/UO2 CORE. UO2 AXIAL ANO RADIAL BLANKETS

(2 CORE ZONES)

$\begin{array}{cc} & \text { CAPACIT } \\ \text { YEAR } & \text { FACTOR } \\ 1 & 0.6000 \\ 2 & 0.6600 \\ 3 & 0.7200 \\ 4 & 0.7200 \\ 5 & 0.7200 \\ 6 & 0.7200 \\ 7 & 0.7200 \\ 8 & 0.7200 \\ 9 & 0.7200 \\ 10 & 0.7200 \\ 11 & 0.7200 \\ 12 & 0.7200 \\ 13 & 0.7200 \\ 14 & 0.7200 \\ 15 & 0.7200 \\ 16 & 0.7200 \\ 17 & 0.7040 \\ 18 & 0.6890 \\ 19 & 0.6730 \\ 20 & 0.6570 \\ 21 & 0.5410 \\ 22 & 0.6260 \\ 23 & 0.6100 \\ 24 & 0.5940 \\ 25 & 0.5740 \\ 26 & 0.5630 \\ 27 & 0.5470 \\ 28 & 0.5310 \\ 29 & 0.5160 \\ 30 & 0.5000\end{array}$

\begin{tabular}{|c|c|c|c|}
\hline 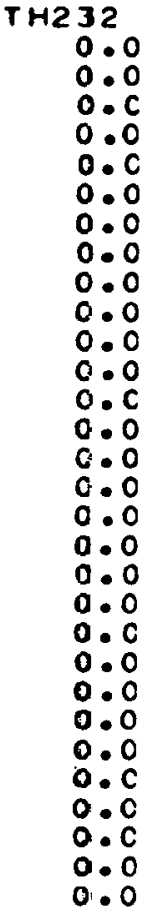 & 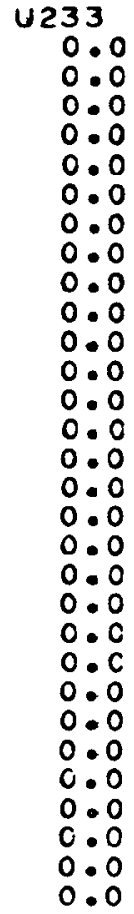 & $\begin{array}{l}4235 \\
115 \cdot 3 \\
31 \cdot 0 \\
33 \cdot 9 \\
33 \cdot 9 \\
33 \cdot 9 \\
33 \cdot 9 \\
33 \cdot 9 \\
33 \cdot 9 \\
33 \cdot 9 \\
33 \cdot 9 \\
33 \cdot 9 \\
33 \cdot 9 \\
33 \cdot 9 \\
33 \cdot 9 \\
33 \cdot 9 \\
33 \cdot 9 \\
33 \cdot 1 \\
32 \cdot 4 \\
31 \cdot 7 \\
30.9 \\
30.2 \\
29 \cdot 4 \\
28.7 \\
27 \cdot 9 \\
27 \cdot 2 \\
26 \cdot 5 \\
25 \cdot 7 \\
25.0 \\
24.3 \\
23.5\end{array}$ & 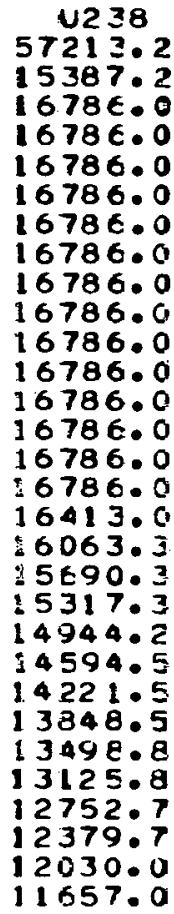 \\
\hline
\end{tabular}

PU239
$1891 \cdot 6$
$737 \cdot 2$
$804 \cdot 2$
$804 \cdot 2$
$804 \cdot 2$
$804 \cdot 2$
$804 \cdot 2$
$804 \cdot 2$
$804 \cdot 2$
$804 \cdot 2$
$804 \cdot 2$
$804 \cdot 2$
$804 \cdot 2$
$804 \cdot 2$
$804 \cdot 2$
$804 \cdot 2$
$786 \cdot 4$
$769 \cdot 6$
$751 \cdot 7$
$733 \cdot 9$
$716 \cdot 0$
$699 \cdot 2$
$681 \cdot 4$
$663 \cdot 5$
$646 \cdot 7$
$628 \cdot 9$
$611 \cdot 0$
$593 \cdot 1$
$576 \cdot 4$
558.5
67

PU240
542.6
$211 \cdot 4$
230.6
230.6
230.6
230.6
230.6
230.6
230.6
230.6
230.6
230.6
230.6
230.6
230.6
230.6
225.5
220.7
215.6
210.5
205.3
200.5
195.4
190.3
105.5
100.4
175.2
170.1
165.3
160.2

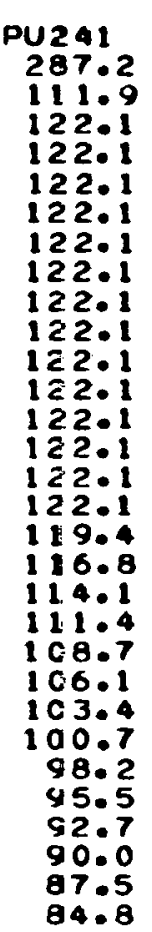

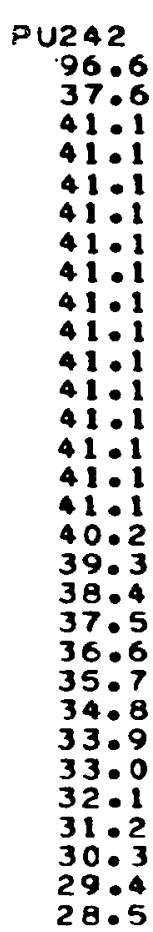
FISSILE TOTAL $2178.7 \quad 60146.4$ 849.116516 .4 926.318017 .9 $026 \cdot 3$ 926.318017 .9 $925.3 \quad 18017.9$ $926.3 \quad 18017.9$ $926.3 \quad 18017.9$ $926.3 \quad 18017.9$ 926.318017 .9 926.318017 .9 $926.3 \quad 18017.9$ 926.318017 .9 $926.3 \quad 18017.9$ 926.3 18017.9 $926.3 \quad 18017.9$ 905.7 17617.5 $886.4 \quad 17242.2$ 865.816841 .8 $845.3 \quad 16441.4$ 824.7 16041.0 $805.4 \quad 15665.6$ $784.8 \quad 15265.6$ 764.215265 .2 $764.2 \quad 14864.8$ $724.3 \quad 14089.0$ $724 \cdot 3 \quad 14089.0$ $683.2 \quad 13688.6$ $683.213288 \cdot 2$ $\begin{array}{ll}663.9 & 12912.8 \\ 643.3 & 12512.5\end{array}$ 


\section{Table 3.5}

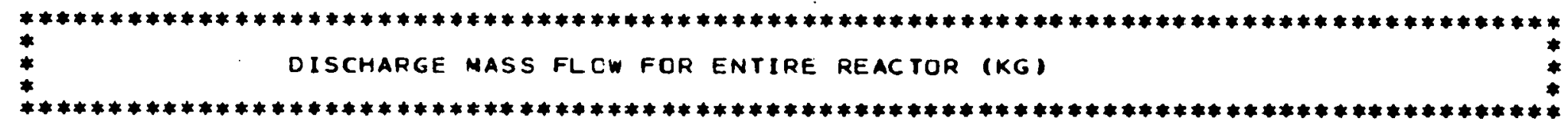

RE ACTOR I DENTIFICATION: URU-TH MIN. DENATURED LMFBR O 1200 MWE (RZ MODELI UO2 CORE, UO2 AXIAL BLANKETS.TMO2 RADIAL GLANKET

$(2$ CORE zONES

CAPACITY

$\begin{array}{ccc}\text { CAPACITY } \\ \text { YEAF FACTOR } & \text { TH232 } \\ 1 & 0.6000 & 4760.6 \\ 2 & 0.0600 & 5208.7 \\ 3 & 0.7200 & 5651.4 \\ 4 & 0.7200 & 5620.0 \\ 5 & 0.7200 & 5588.5 \\ 6 & 0.7200 & 555.7 .1 \\ 7 & 0.7200 & 5554.4 \\ 8 & 0.7200 & 5552.7 \\ 9 & 0.7200 & 5551.4 \\ 10 & 0.7200 & 5550.8 \\ 11 & 0.7200 & 5550.5 \\ 12 & 0.7200 & 5550.5 \\ 13 & 0.7200 & 5550.5 \\ 14 & 0.7200 & 5550.5 \\ 15 & 0.7200 & 5550.5 \\ 16 & 0.7200 & 5550.5 \\ 17 & 0.7040 & 5427.1 \\ 18 & 0.6890 & 5311.5 \\ 19 & 0.6730 & 5188.2 \\ 20 & 0.6570 & 5064.8 \\ 21 & 0.6410 & 4941.5 \\ 22 & 0.6260 & 4825.8 \\ 23 & 0.6100 & 4702.5 \\ 24 & 0.5940 & 4579.1 \\ 25 & 0.5790 & 4463.5 \\ 26 & 0.5630 & 4340.2 \\ 27 & 0.5470 & 4216.8 \\ 28 & 0.5310 & 4093.5 \\ 29 & 0.5160 & 3977.8 \\ 30 & 0.5000 & 23458.2\end{array}$

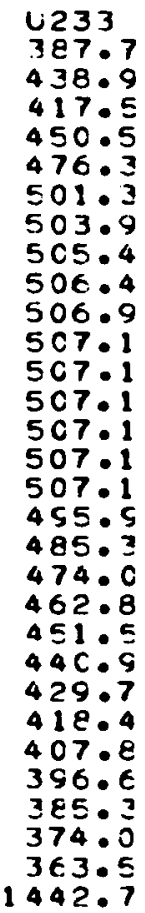

$\begin{array}{ll}4235 & 1238 \\ 15.5 & 9176.8 \\ 13.8 & 9647.5 \\ 12.5 & 10179.9 \\ 12.5 & 10179.7 \\ 12.5 & 10181.7 \\ 12.6 & 10185.7 \\ 12.6 & 10187.7 \\ 12.6 & 10188.6 \\ 12.6 & 10198.9 \\ 12.6 & 10189.0 \\ 12.6 & 10189.1 \\ 12.6 & 10189.1 \\ 12.6 & 10189.1 \\ 12.6 & 10189.1 \\ 12.6 & 10189.1 \\ 12.6 & 10185.1 \\ 12.3 & 9562.7 \\ 12.1 & 9750.4 \\ 11.8 & 9524.0 \\ 11.5 & 9297.6 \\ 11.2 & 9071.1 \\ 11.0 & 8856.9 \\ 10.7 & 8632.4 \\ 10.4 & 8406.0 \\ 10.1 & 8193.8 \\ 9.9 & 7967.3 \\ 9.6 & 7740.9 \\ 9.3 & 7514.5 \\ 9.0 & 7302.2 \\ 31.9 & 21786.0\end{array}$

$\begin{array}{lr}\text { PU239 } & \text { PU240 } \\ 198.4 & 5.6 \\ 368.8 & 20.0 \\ 527.7 & 42.4 \\ 523.8 & 41.3 \\ 523.2 & 41.1 \\ 521.5 & 40.7 \\ 520.7 & 40.5 \\ 520.3 & 40.4 \\ 520.2 & 40.4 \\ 520.1 & 40.4 \\ 520.1 & 40.4 \\ 520.1 & 40.4 \\ 520.1 & 40.4 \\ 520.1 & 40.4 \\ 520.1 & 40.4 \\ 520.1 & 40.4 \\ 508.5 & 39.5 \\ 497.7 & 38.6 \\ 486.1 & 37.7 \\ 474.6 & 36.8 \\ 463.0 & 36.0 \\ 452.2 & 35.1 \\ 440.6 & 34.2 \\ 429.1 & 33.3 \\ 418.2 & 32.5 \\ 406.7 & 31.6 \\ 395.1 & 30.7 \\ 383.6 & 29.8 \\ 372.7 & 28.9 \\ 786.1 & 46.1\end{array}$

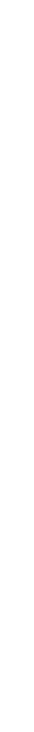

FISSILE

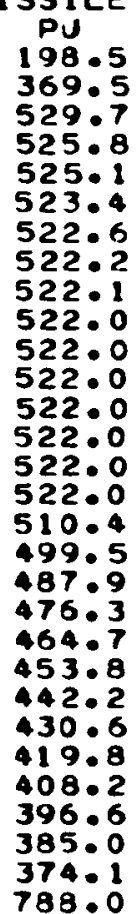

TOTAL 14544.8 15698.5 16833.4 16829.9 $16825 \cdot 4$ 16820.8 $16821 \cdot 7$ 16822.0 16821.9 16821.8 16821.8 16821.8 16821.8 16821.8 16821.8 16821.8 16448.0 16448.0 16097.5 15723.7 15349 14976.1 14625.6 14251.8 13878.0 13527.5 13153.7 12779.9 12406.1 12055.6 
Table 3.6

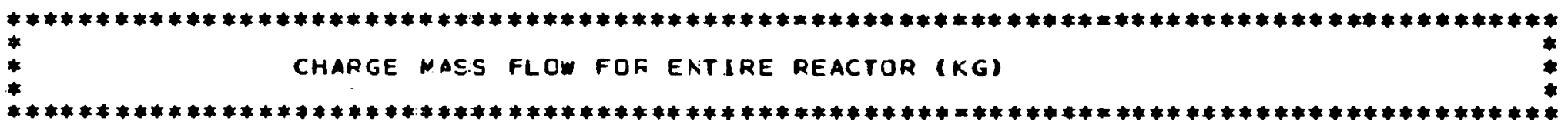

REACTOR IDENTIFICATICN: U/L-TH MIN. DENATURED LMFBR A 1200 MWE (RZ MODEL)
UO2 COPE.UD2 AXIAL BLANKETS.THO2 RADIAL BLANKET

( 2 CORE ZONES

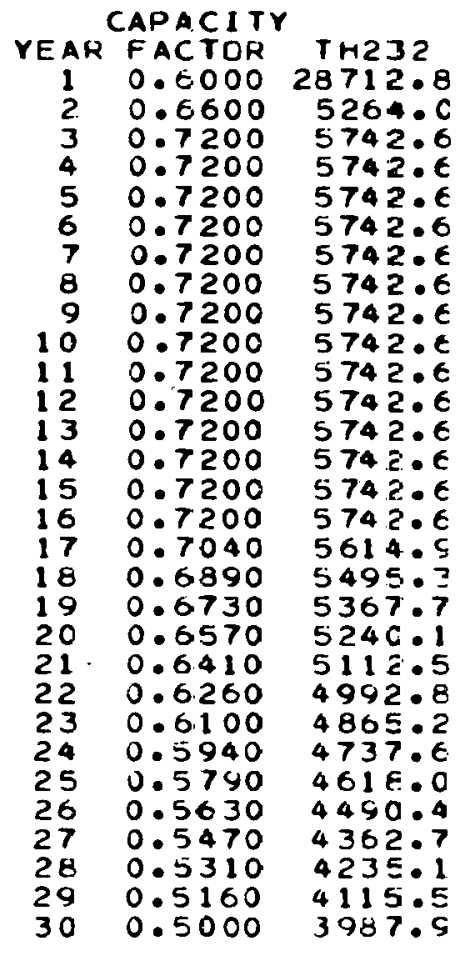

1233
1956.8
839.1
915.4
915.4
915.4
915.4
915.4
915.4
915.4
915.4
915.4
915.4
915.4
915.4
915.4
915.4
855.0
876.1
855.6
835.3
214.9
795.9
775.5
755.2
736.1
715.8
695.4
675.1
656.0
635.7

\begin{tabular}{|c|c|}
\hline 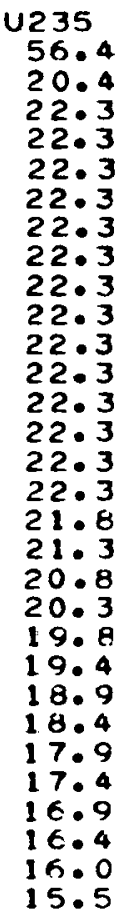 & 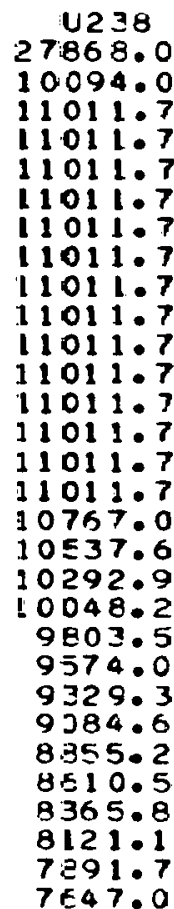 \\
\hline
\end{tabular}

P

$\begin{array}{rr}\text { U. 39 } & \text { PU240 } \\ 0.0 & 0.0 \\ 0.0 & 0.0 \\ 0.0 & 0.0 \\ 0.0 & 0.0 \\ 0.0 & 0.0 \\ 0.0 & 0.0 \\ 0.0 & 0.0 \\ 0.0 & 0.0 \\ 0.0 & 0.0 \\ 0.0 & 0.0 \\ 0.0 & 0.0 \\ 0.0 & 0.0 \\ 0.0 & 0.0 \\ 0.0 & 0.0 \\ 0.0 & 0.0 \\ 0.0 & 0.0 \\ 0.0 & 0.0 \\ 0.0 & 0.0 \\ 0.0 & 0.0 \\ 0.0 & 0.0 \\ 0.0 & 0.0 \\ 0.0 & 0.0 \\ 0.0 & 0.0 \\ 0.0 & 0.0 \\ 0.0 & 0.0 \\ 0.0 & 0.0 \\ 0.0 & 0.0 \\ 0.0 & 0.0 \\ 0.0 & 0.0 \\ 0.0 & 0.0 \\ & \end{array}$

$F \cup 1$
0.0
0.0
0.0
0.0
0.0
0.0
0.0
0.0
0.0
0.0
0.0
0.0
0.0
0.0
0.0
0.0
0.0
0.0
0.0
0.0
0.0
0.0
0.0
0.0
0.0
0.0
0.0
0.0
0.0
0.0

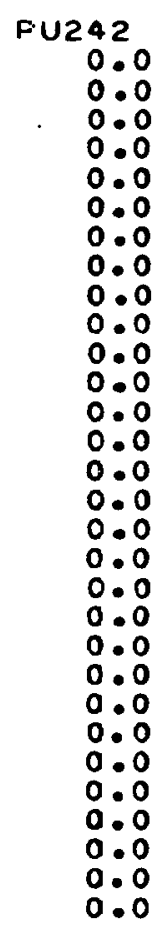

FISSILE Pu 0.0 16594.0 $0.0 \quad 17691: 9$ $0.0 \quad 17691.9$ $0.0 \quad 17691.9$ $0.0 \quad 17691.9$ $0.0 \quad 17691.9$ 0.017691 .9 $0.017691 \cdot 9$ $0.0 \quad 17691 \cdot 9$ 17691.9 $0.0 \quad 17691.9$ $0.0 \quad 17691.9$

$0.0 \quad 17691.9$

0.017691 .9

$0.0 \quad 17691.9$

0.017691 .9

$0.0 \quad 17298.7$

0.016930 .2

$0.0 \quad 16537.0$

$0.0 \quad 16143.9$

$0.0 \quad 15750.7$

$0.0 \quad 15382.1$

$0.0 \quad 14989.0$

0.014595 .0

0.014227 .2

0.01422.

$0.0 \quad 13450.1$

$0.0 \quad 13440.9$

0.013047 .8

$\begin{array}{ll}0.0 & 12679.2 \\ 0.0 & 12286.0\end{array}$ 
Table 3.7

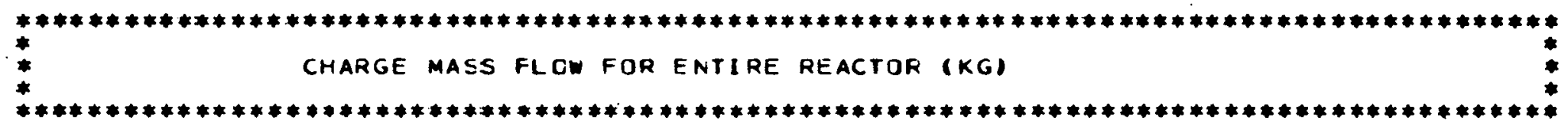

FEACTOR IDENTIFICATION :

U/TH MIN D DENA TURED LMFER D 1200 MWE

IRZ $^{2}$

MOOEL) 2 CORE ZOVES) $(6 / 09 / 77)$ CAPACITY

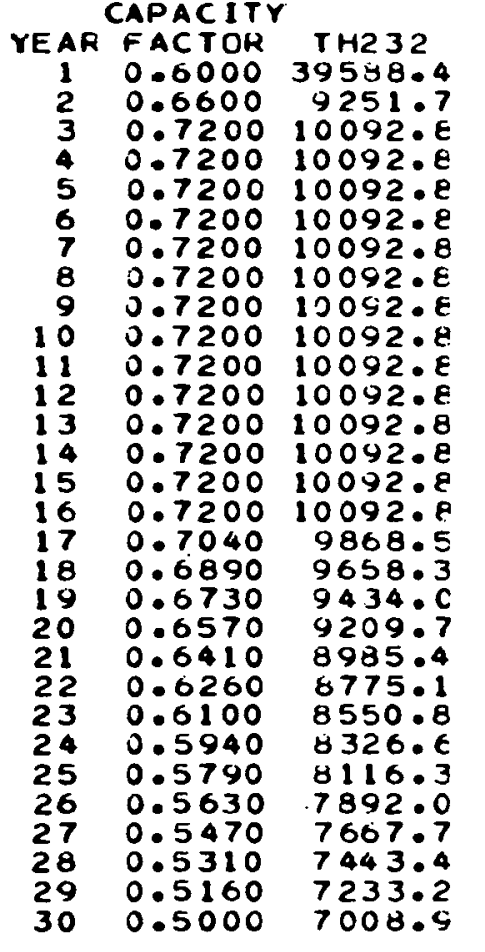

4233
$1973 \cdot 4$
$846 \cdot 2$
$923 \cdot 2$
$923 \cdot 2$
$923 \cdot 2$
$923 \cdot 2$
$923 \cdot 2$
$923 \cdot 2$
$923 \cdot 2$
$923 \cdot 2$
$923 \cdot 2$
$923 \cdot 2$
$923 \cdot 2$
$923 \cdot 2$
$923 \cdot 2$
$923 \cdot 2$
$902 \cdot 6$
$883 \cdot 4$
$862 \cdot 9$
$842 \cdot 4$
$821 \cdot 9$
$862 \cdot 6$
$782 \cdot 1$
$761 \cdot 6$
742.4
$721 \cdot 9$
$701 \cdot 3$
680.8
661.6
641.1

\begin{tabular}{|c|c|}
\hline 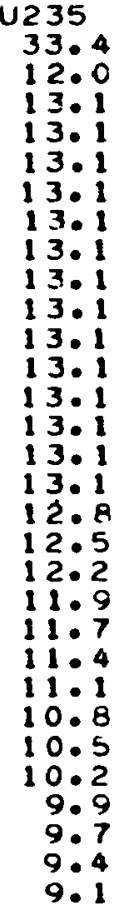 & 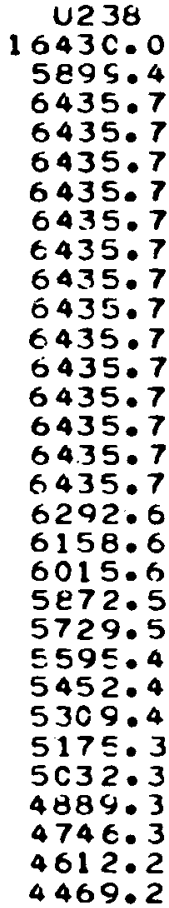 \\
\hline
\end{tabular}

$P \cup 29$
0.0
0.0
0.0
0.0
0.0
0.0
0.0
0.0
0.0
0.0
0.0
0.0
0.0
0.0
0.0
0.0
0.0
0.0
0.0
0.0
0.0
0.0
0.0
0.0
0.0
0.0
0.0
0.0
0.0
0.0

$\begin{array}{lr}239 & P \cup 240 \\ 0.0 & 0.0 \\ 0.0 & 0.0 \\ 0.0 & 0.0 \\ 0.0 & 0.0 \\ 0.0 & 0.0 \\ 0.0 & 0.0 \\ 0.0 & 0.0 \\ 0.0 & 0.0 \\ 0.0 & 0.0 \\ 0.0 & 0.0 \\ 0.0 & 0.0 \\ 0.0 & 0.0 \\ 0.0 & 0.0 \\ 0.0 & 0.0 \\ 0.0 & 0.0 \\ 0.0 & 0.0 \\ 0.0 & 0.0 \\ 0.0 & 0.0 \\ 0.0 & 0.0 \\ 0.0 & 0.0 \\ 0.0 & 0.0 \\ 0.0 & 0.0 \\ 0.0 & 0.0 \\ 0.0 & 0.0 \\ 0.0 & 0.0 \\ 0.0 & 0.0 \\ 0.0 & 0.0 \\ 0.0 & 0.0 \\ 0.0 & 0.0 \\ 0.0 & 0.0\end{array}$

\begin{tabular}{|c|}
\hline 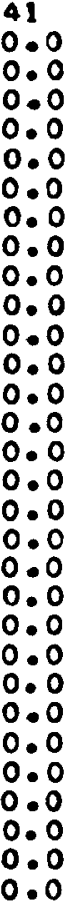 \\
\hline
\end{tabular}

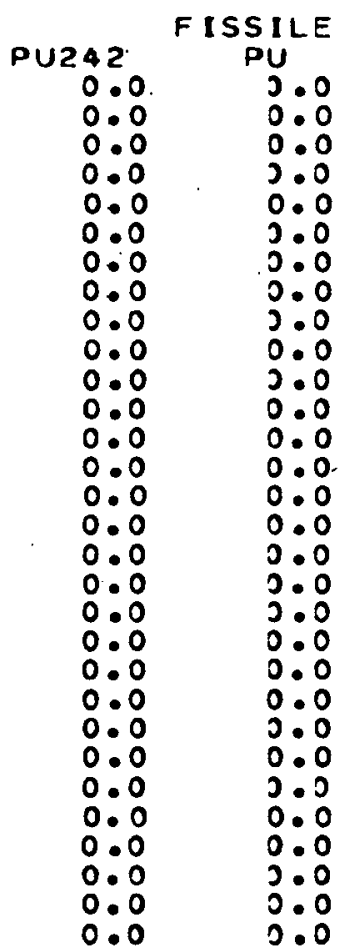

TOTAL

58025

$58025 \cdot 3$

$17464: 7$

17464.7

17464.7

$17464 \cdot 7$

17464.7

$17464 \cdot 7$

$17464 \cdot 7$

17464.7

$17464: 7$

$17464: 7$

$17464: 7$

$17464: 7$

17464.7

16712.8

16324.6

15936.5

15548.4

15184.6

14408.4

14408.4

$14044 \cdot 5$

13656.4

3.012880 .2

12516.4 
Table 3.8

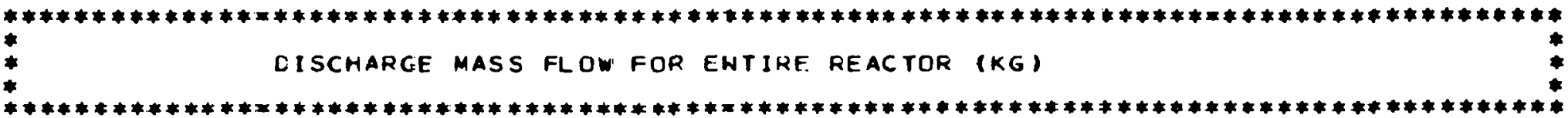

REACTOR IDENTIFICATION : U/TH MIN. JENATURED LMFBR D 1200 MWE (RZ MODEL) (ERE ZONES) (6/O9/7T)

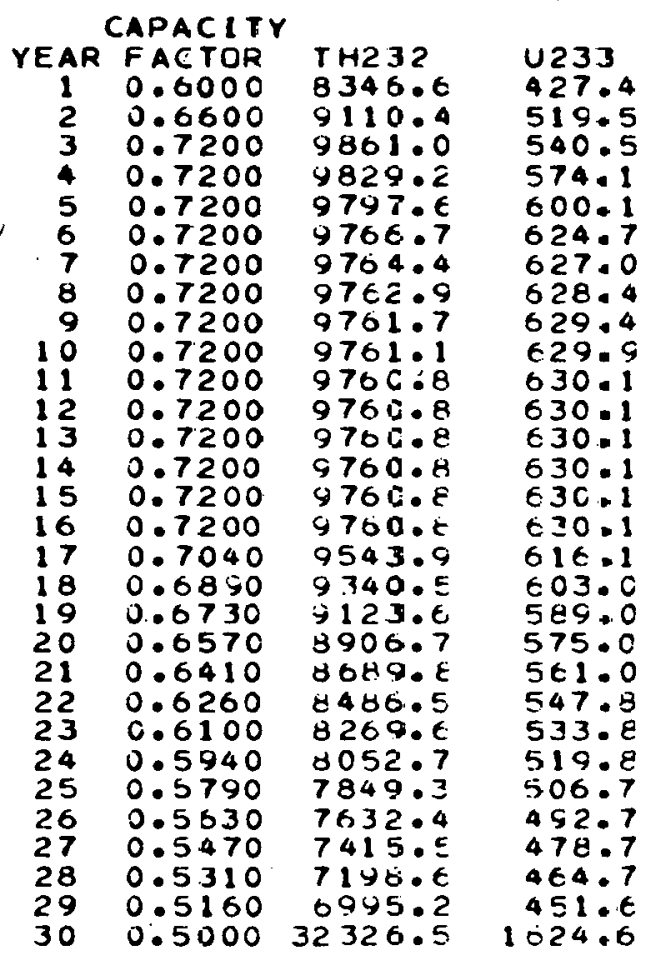

\begin{tabular}{|c|c|c|c|c|}
\hline $\begin{array}{l}235 \\
8 \cdot 5 \\
6: 9 \\
5: 6 \\
5: 7 \\
5: 7 \\
5: 7 \\
5: 7 \\
5: 7 \\
5: 7 \\
5: 7 \\
5: 7 \\
5: 7 \\
5: 7 \\
5: 7 \\
5: 7 \\
5: 7 \\
5: 6 \\
5: 5 \\
5: 4 \\
5: 2 \\
5 \cdot 1 \\
5: 0 \\
4: 9 \\
4: 7 \\
4: 6 \\
4: 5 \\
4: 4 \\
4: 2 \\
4: 1 \\
16.1\end{array}$ & 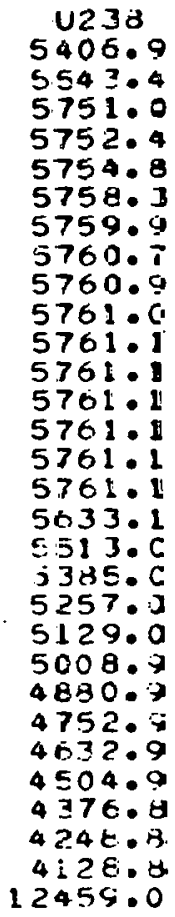 & $\begin{array}{r}\text { PU2 39 } \\
160.9 \\
290.2 \\
404.7 \\
400.7 \\
379.9 \\
398.6 \\
378.0 \\
397.7 \\
397.7 \\
397.6 \\
397.6 \\
397.6 \\
397.6 \\
397.6 \\
377.6 \\
397.6 \\
338.8 \\
330.5 \\
371.6 \\
302.8 \\
354.0 \\
345.7 \\
3.36 .8 \\
328.0 \\
319.7 \\
310.9 \\
302.1 \\
273.2 \\
284.9 \\
610.0\end{array}$ & $\begin{array}{r}P \cup 240 \\
5.1 \\
17.8 \\
37.2 \\
36.1 \\
35.8 \\
35.5 \\
35.3 \\
35.2 \\
35.2 \\
35.2 \\
35.2 \\
35.2 \\
35.2 \\
35.2 \\
35.2 \\
35.2 \\
34.4 \\
33.7 \\
32.9 \\
32.1 \\
31.3 \\
30.6 \\
29.8 \\
29.0 \\
28.3 \\
27.5 \\
26.7 \\
35.9 \\
25.2 \\
40.4\end{array}$ & $\begin{array}{r}\text { PUz } 41 \\
0 . \\
0 .\end{array}$ \\
\hline
\end{tabular}

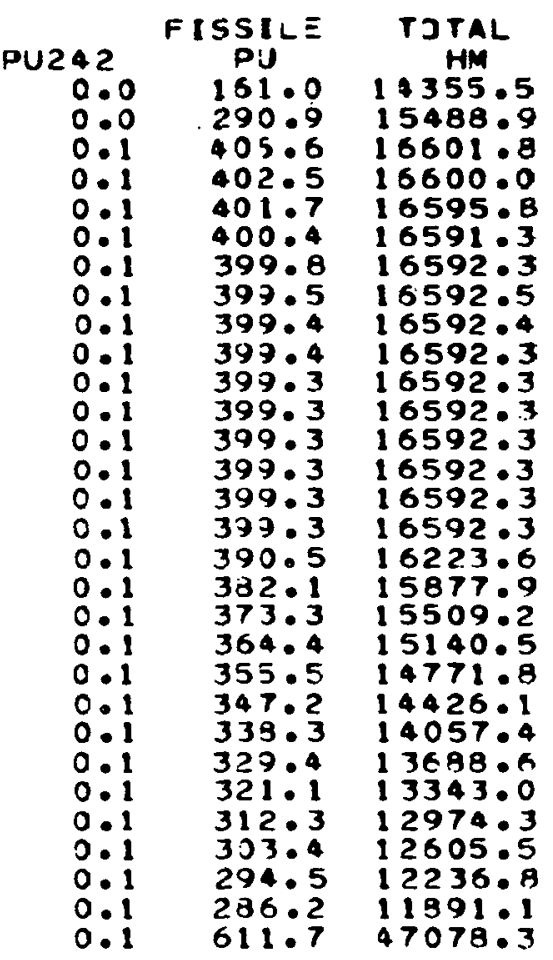


Table 3.9

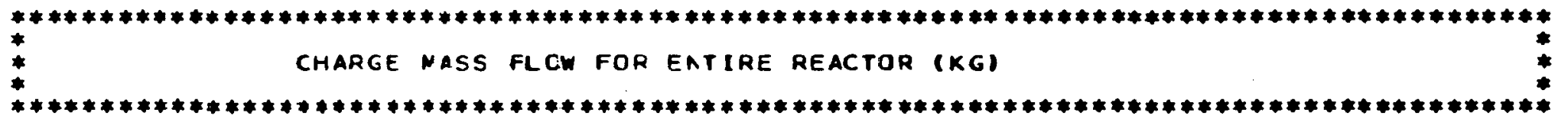
REACTOR IDENTIFICATICN : U-TH/TH 20X CENATURED LMFBR D 1200 MWE (RZ MODEL)
U/THOZ CORE. THOZ AXIAL AND RADIAL BLANKETS (6RE ZONES)

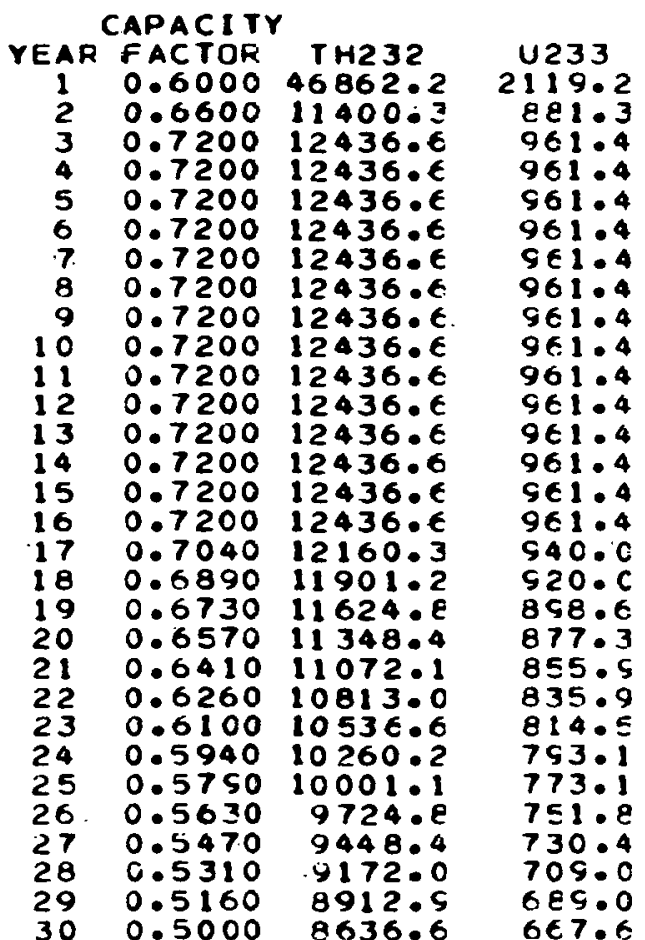

\begin{tabular}{|c|c|}
\hline $\begin{array}{r}235 \\
17.6 \\
6.9 \\
7.5 \\
7.5 \\
7.5 \\
7.5 \\
7.5 \\
7.5 \\
7.5 \\
7.5 \\
7.5 \\
7.5 \\
7.5 \\
7.5 \\
7.5 \\
7.5 \\
7.5 \\
7.5 \\
7.0\end{array}$ & $\begin{array}{l}1238 \\
8644.0 \\
3594.2 \\
3920.9 \\
3920.9 \\
3920.9 \\
3920.9 \\
3520.9 \\
3520.9 \\
3920.9 \\
3920.9 \\
3920.9 \\
3920.9 \\
3920.9 \\
3920.9 \\
3920.9 \\
3920.9 \\
3633.8 \\
3752.1 \\
3665.0 \\
3577.9 \\
3490.7 \\
3409.0 \\
3321.9 \\
3234.8 \\
3153.1 \\
3666.0\end{array}$ \\
\hline
\end{tabular}

PU2 39
0.0
0.0
0.0
0.0
0.0
0.0
0.0
0.0
0.0
0.0
0.0
0.0
0.0
0.0
0.0
0.0
0.0
0.0
0.0
0.0
0.0
0.0
0.0
0.0
0.0
0.0
0.0
0.0
0.0
0.0
0.0

$\begin{array}{ll}P \cup & 0 \\ 0.0 \\ 0.0 \\ 0.0 \\ 0.0 \\ 0.0 \\ 0.0 \\ 0.0 \\ 0.0 \\ 0.0 \\ 0.0 \\ 0.0 \\ 0.0 \\ 0.0 \\ 0.0 \\ 0.0 \\ 0.0 \\ 0.0 \\ 0.0 \\ 0.0 \\ 0.0 \\ 0.0 \\ 0.0 \\ 0.0 \\ 0.0 \\ 0.0 \\ 0.0 \\ 0.0 \\ 0.0 \\ 0.0 \\ 0.0 \\ 0\end{array}$

Pu2
0.1
0.0
0.0
0.0
0.0
0.0
0.0
0.0
0.0
0.0
0.0
0.0
0.0
0.0
0.0
0.0
0.0
0.0
0.0
0.0
0.0
0.0
0.0
0.0
0.0
0.0
0.0

$\begin{array}{lr}41 & P \cup 242 \\ 0.0 & 0.0 \\ 0.0 & 0.0 \\ 0.0 & 0.0 \\ 0.0 & 0.0 \\ 0.0 & 0.0 \\ 0.0 & 0.0 \\ 0.0 & 0.0 \\ 0.0 & 0.0 \\ 0.0 & 0.0 \\ 0.0 & 0.0 \\ 0.0 & 0.0 \\ 0.0 & 0.0 \\ 0.0 & 0.0 \\ 0.0 & 0.0 \\ 0.0 & 0.0 \\ 0.0 & 0.0 \\ 0.0 & 0.0 \\ 0.0 & 0.0 \\ 0.0 & 0.0 \\ 0.0 & 0.0 \\ 0.0 & 0.0 \\ 0.0 & 0.0 \\ 0.0 & 0.0 \\ 0.0 & 0.0 \\ 0.0 & 0.0 \\ 0.0 & 0.0 \\ 0.0 & 0.0 \\ 0.0 & 0.0 \\ 0.0 & 0.0 \\ 0.0 & 0.0 \\ 0 & \end{array}$

FISSILE PU 0.0

TOTAL

$0.0 \quad 15882.0$ 0.017326 .4 0.017326 .4 0.017326 .4 0.017326 .4 0.017326 .4 0.017326 .4 0.017326 .0 0.017326 .4 0.017326 .4 0.017326 .4 0.017326 .4 0.0 1732604 (17326.4 0.017326 .4 16941.4 0.0 16941.4 0.016580 .4 0.016195 .4 0.015810 .4 0.015425 .3 0.015064 .4 14679.3 $0.0 \quad 14294.3$ $0.0 \quad 13933.3$ 0.013548 .3 0.013163 .3 $0.0 \quad 12778.2$ 0.012417 .3 


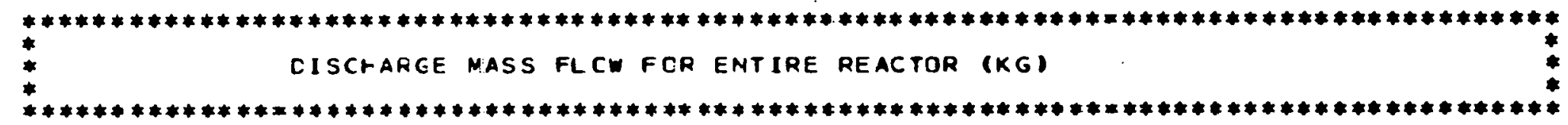

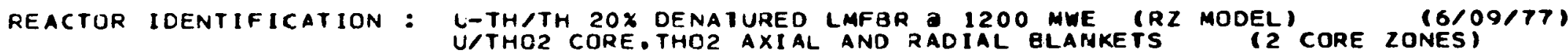

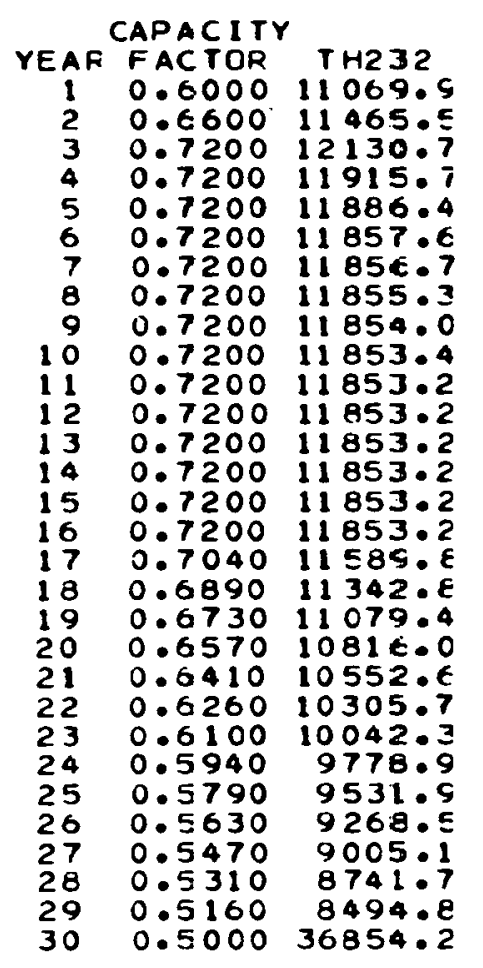

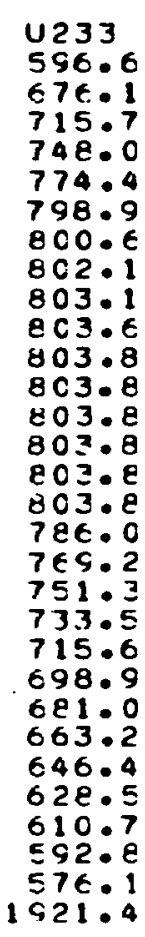

\begin{tabular}{|c|c|}
\hline 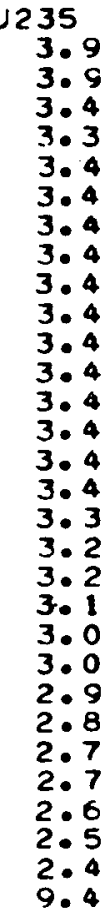 & 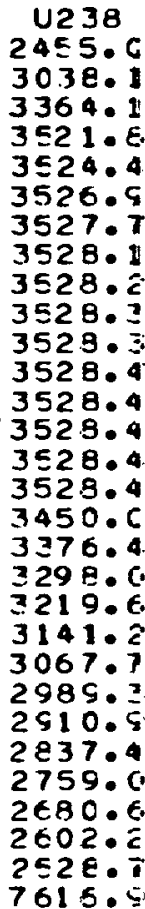 \\
\hline
\end{tabular}

$\begin{array}{rr}P \cup 239 & P \cup 240 \\ 6.9 .2 & 2.0 \\ 152.2 & 8.8 \\ 227.5 & 19.7 \\ 235.8 & 20.0 \\ 234.8 & 19.8 \\ 233.9 & 19.5 \\ 233.6 & 19.4 \\ 233.4 & 19.4 \\ 233.4 & 19.3 \\ 233.3 & 19.3 \\ 233.3 & 19.3 \\ 233.3 & 19.3 \\ 233.3 & 19.3 \\ 233.3 & 19.3 \\ 233.3 & 19.3 \\ 233.3 & 19.3 \\ 228.1 & 18.9 \\ 223.3 & 18.5 \\ 218.1 & 18.1 \\ 212.9 & 17.6 \\ 207.7 & 17.2 \\ 262.9 & 16.8 \\ 197.7 & 16.4 \\ 192.5 & 16.0 \\ 187.6 & 15.5 \\ 182.4 & 15.1 \\ 177.3 & 14.7 \\ 172.1 & 14.3 \\ 167.2 & 13.9 \\ 356.3 & 22.1 \\ & \end{array}$

PU2 11
0.0
0.3
1.0
1.00
0.9
0.9
0.9
0.9
0.9
0.9
0.9
0.9
0.9
0.9
0.9
0.9
0.9
0.9
0.8
0.8
0.9
0.8
0.8
0.7
0.7
0.7
0.7
0.7
0.6
0.9

FISSILE

0.2
0.0
0.0
0.0
0.0
0.0
0.0
0.0
0.0
0.0
0.0
0.0
0.0
0.0
0.0
0.00
0.0
0.0
0.0
0.0
0.0
0.0
0.0
0.00
0.0
0.0
0.0
0.0
0.0
0.0
0.0

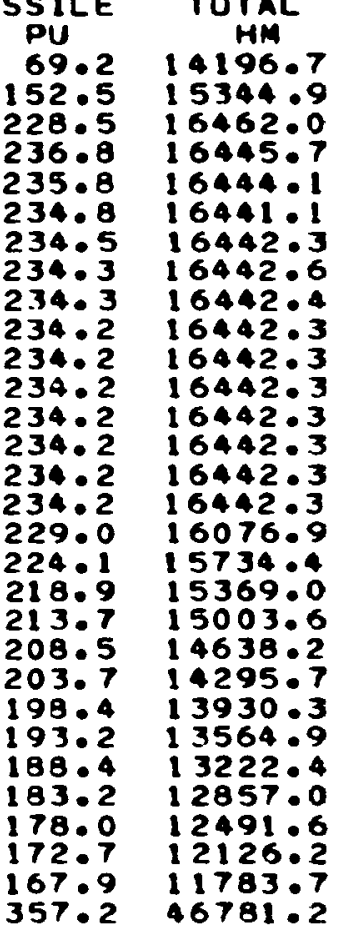


Table 3.11

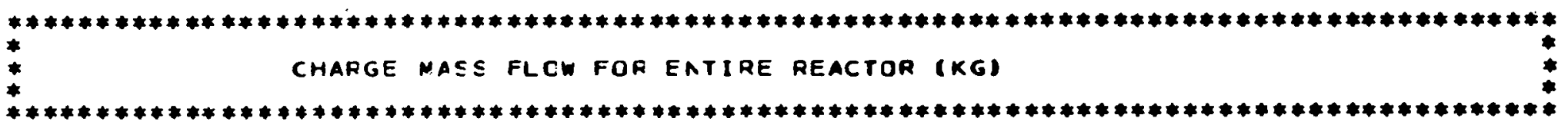

REACTOR ICENTIFICATICN : U-TH/TH $40 X$ DENATURED LMFBR 1200 MWE (RZ MODEL) (ORE ZONESI $16 / 77$ )

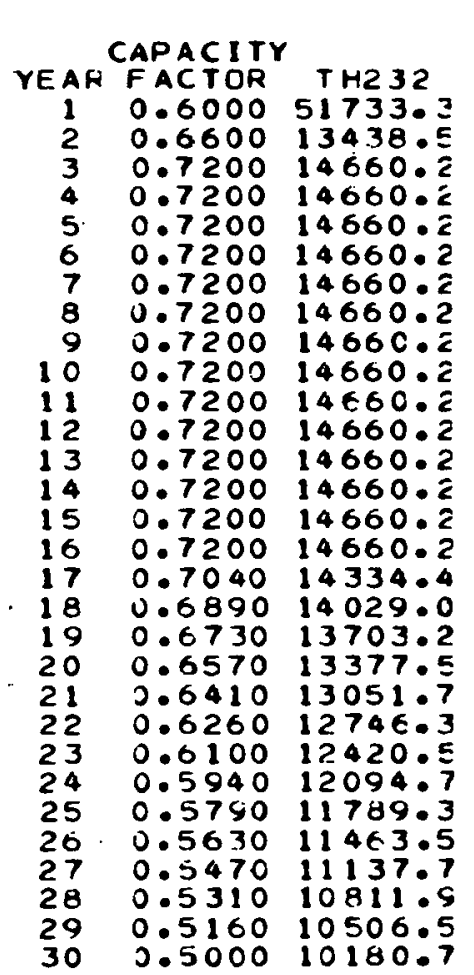

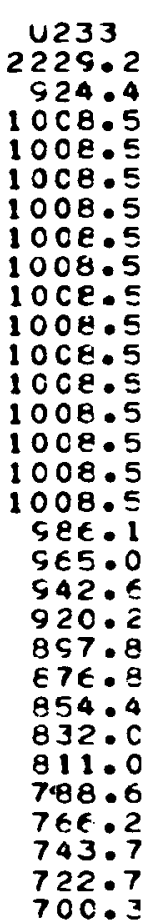

\begin{tabular}{|c|c|}
\hline $\begin{array}{l}235 \\
6.9 \\
2.9 \\
3.1 \\
3.1 \\
3.1 \\
3.1 \\
3.1 \\
3.1 \\
3.1 \\
3.1 \\
3.1 \\
3.1 \\
3.1 \\
3.1 \\
3.1 \\
3.1 \\
3.1 \\
3.0 \\
2.9 \\
2.9 \\
2.08 \\
2.07 \\
2.7 \\
2.0 \\
2.5 \\
2.5 \\
2.4\end{array}$ & 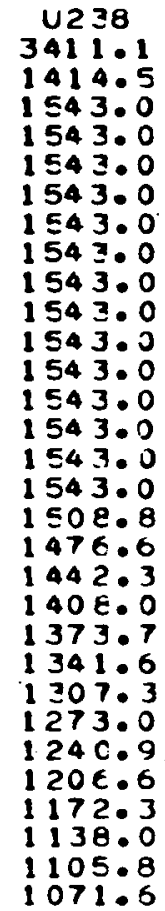 \\
\hline
\end{tabular}

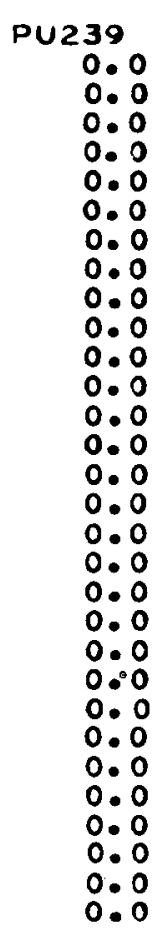

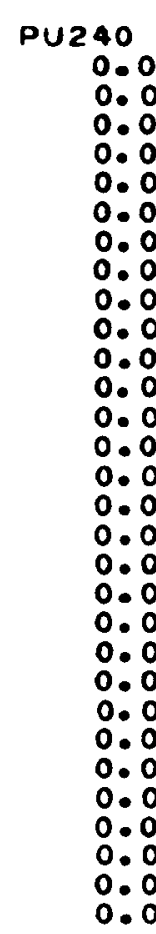

PU241
0.0
0.0
0.0
0.0
0.0
0.0
0.0
0.00
0.0
0.0
0.0
0.0
0.0
0.0
0.0
0.0
0.0
0.0
0.0
0.0
0.00
0.0
0.00
0.0
0.0
0.0
0.00
0.0
0.0
0.00
0

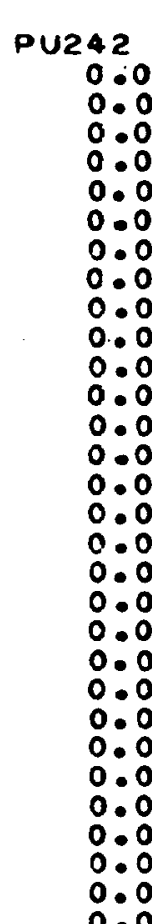

FISSILE TOTAL PU. 57380.5 $0.0057380 \cdot 5$ 0.017214 .9 $0.0 \quad 17214.9$ 0.017214 .9 $0.0 \quad 17214.9$ 0.017214 .9 0.017214 .9 0.017214 .9 0.017214 .9 0.017214 .9 $0.0 \quad 17214.9$ 0.0 1 72109 $0.0 \quad 17214.9$ $0.0 \quad 17214.9$ 0.017214 .9 0.017214 .9 $0.016832 \cdot 3$

0.016473 .7 .

$0.0 \quad 16091.1$

0.015708 .6

$0.0 \quad 15326.0$

0.014967 .4

$0.0 \quad 14584.8$

$0.0 \quad 142.02 .3$

13461.1

$0.0 \quad 13078.5$

0.012696 .0

0.012337 .3 


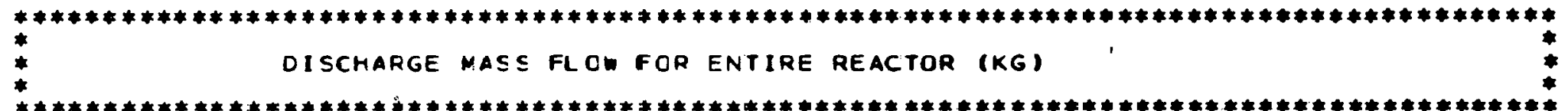

REACTOR IOENTIFICATION: L-TH'TH 4OY OENATUREC LMFBR O 1200 MME (RZ MODEL)
UTTHOZ CORE. THOZ AXI ANO RADIAL ABLANKETS (6/09)

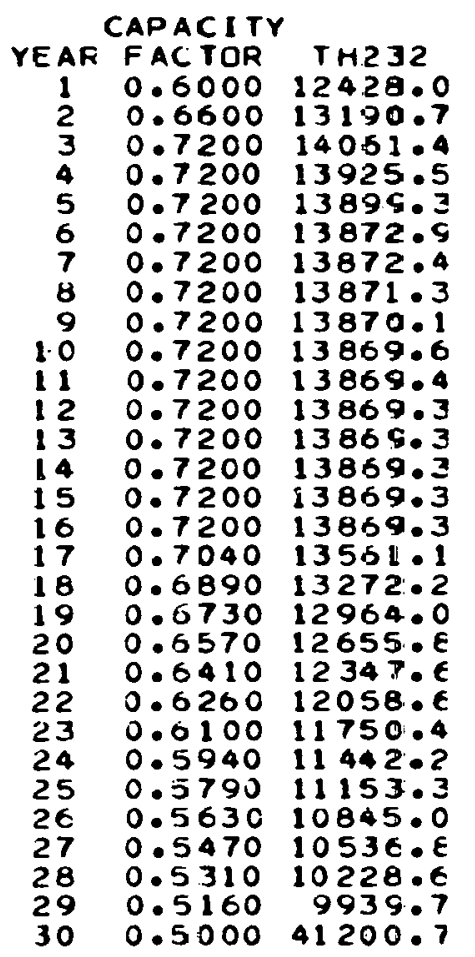

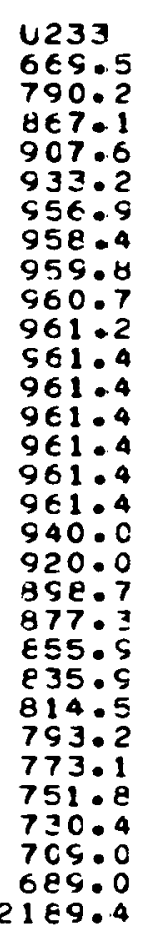

\begin{tabular}{|c|c|c|}
\hline 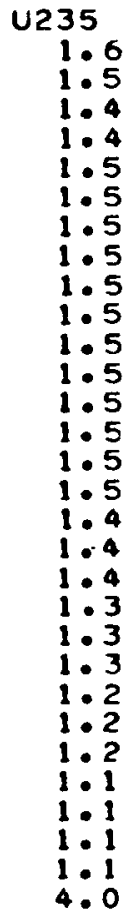 & $\begin{array}{r}1233 \\
583.8 \\
1197.2 \\
1317.9 \\
1389.4 \\
1390.6 \\
1391.6 \\
1391.9 \\
1392.1 \\
1392.1 \\
1392.1 \\
1392.1 \\
1392.1 \\
1392.1 \\
1392.1 \\
1392.1 \\
1392.1 \\
1361.2 \\
1332.2 \\
1301.3 \\
13270.3 \\
1239.4 \\
1219.4 \\
1210.4 \\
1179.5 \\
1148.5 \\
1115.5 \\
1088.6 \\
1057.6 \\
1026.7 \\
997.7 \\
1002.6\end{array}$ & $\begin{array}{r}\text { P } 239 \\
27.1 \\
58.6 \\
87.1 \\
90.7 \\
90.2 \\
89.8 \\
89.7 \\
89.7 \\
89.7\end{array}$ \\
\hline
\end{tabular}

\begin{tabular}{|c|}
\hline 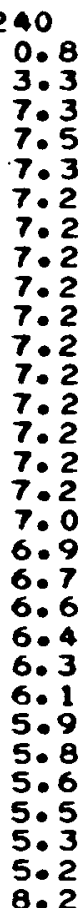 \\
\hline
\end{tabular}

$P \cup 2.1$
0.0
0.1
0.4
0.4
0.3
0.3
0.3
0.3
0.3
0.3
0.3
0.3
0.3
0.3
0.3
0.3
0.3
0.3
0.3
0.3
0.3
0.3
0.3
0.3
0.3
0.3
0.3
0.2
0.2
0.3

FISSILE

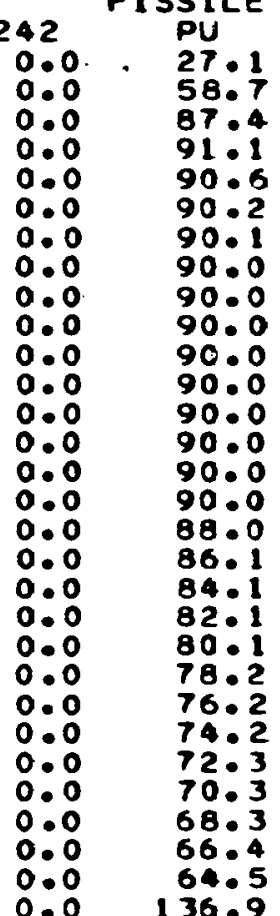

TOTAL HM

14110.8 $15241 \cdot 7$ $16342 \cdot 6$ $16322 \cdot 5$ $16322 \cdot 5$ $16320 \cdot 3$ $16321 \cdot 5$ $16321 \cdot 7$ 16321.6 $16321 \bullet 6$ 16321.5 $16321 \cdot 5$ $16321 \cdot 5$ $16321 \cdot 5$ $16321 \cdot 5$ $16321 \cdot 5$ $16321 \cdot 5$ 15958.8 15618.8 $15256 \cdot 1$ 14893.4 14530.7 14190.6 13827.9 $13465 \cdot 2$ $13125 \cdot 2$ 12762.5 12399.8 12037.1 11697.1 46541.9 
Table 3.13

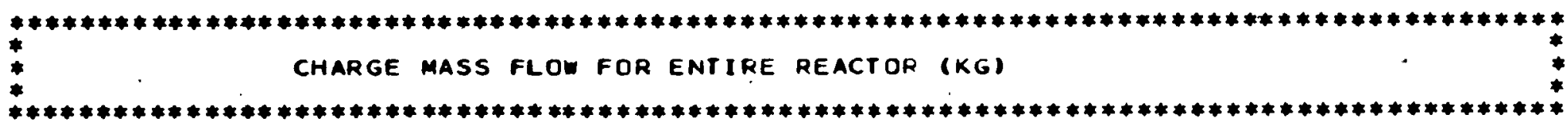

REACTOR IDENTIFICATION: PU-TH/TH LMFBP D 1200 MWE (RL MODEL)

PU/THOZ CORE. THOZ AXIAL AND RAUIAL BLANKETS

$(2$ CORE LONES)

CAPACITY

\begin{tabular}{ccc}
\multicolumn{3}{c}{ CAPACITY } \\
YEAR FACTOR & TH232 \\
1 & 0.6000 & 53892.4 \\
2 & 0.6600 & 14475.4 \\
3 & 0.7200 & 15791.4 \\
4 & 0.7200 & 15791.4 \\
5 & 0.7200 & 15791.4 \\
6 & 0.7200 & 15791.4 \\
7 & 0.7200 & 15791.4 \\
8 & 0.7200 & 15791.4 \\
9 & 0.7200 & 15791.4 \\
10 & 0.7200 & 15791.4 \\
11 & 0.7200 & 15791.4 \\
12 & 0.7200 & 15791.4 \\
13 & 0.7200 & 15791.4 \\
14 & 0.7200 & 15791.4 \\
15 & 0.7200 & 15791.4 \\
16 & 0.7200 & 15791.4 \\
17 & 0.7040 & 15440.5 \\
18 & 0.6890 & 15111.5 \\
19 & 0.6730 & 14760.6 \\
20 & 0.6570 & 14409.6 \\
21 & 0.6410 & 14058.7 \\
22 & 0.6260 & 13729.7 \\
23 & 0.6100 & 13378.8 \\
24 & 0.5940 & 13027.9 \\
25 & 0.5790 & 12698.9 \\
26 & 0.5630 & 12348.0 \\
27 & $0.547 C$ & 11997.1 \\
28 & 0.5310 & 11646.1 \\
29 & 0.5160 & 11317.2 \\
30 & 0.5000 & 10966.2
\end{tabular}

$\begin{array}{crr}u 233 & v 235 & v 238 \\ 0.0 & 0.0 & 0.0 \\ 0.0 & 0.0 & 0.0 \\ 0.0 & 0.0 & 0.0 \\ 0.0 & 0.0 & 0.0 \\ 0.0 & 0.0 & 0.0 \\ 0.0 & 0.0 & 0.0 \\ 0.0 & 0.0 & 0.0 \\ 0.0 & 0.0 & 0.0 \\ 0.0 & 0.0 & 0.0 \\ 0.0 & 0.0 & 0.0 \\ 0.0 & 0.0 & 0.0 \\ 0.0 & 0.0 & 0.0 \\ 0.0 & 0.0 & 0.0 \\ 0.0 & 0.0 & 0.0 \\ 0.0 & 0.0 & 0.0 \\ 0.0 & 0.0 & 0.0 \\ 0.0 & 0.0 & 0.0 \\ 0.0 & 0.0 & 0.0 \\ 0.0 & 0.0 & 0.0 \\ 0.0 & 0.0 & 0.0 \\ 0.0 & 0.0 & 0.0 \\ 0.0 & 0.0 & 0.0 \\ 0.0 & 0.0 & 0.0 \\ 0.0 & 0.0 & 0.0 \\ 0.0 & 0.0 & 0.0 \\ 0.0 & 0.0 & 0.0 \\ 0.0 & 0.0 & 0.0 \\ 0.0 & 0.0 & 0.0 \\ 0.0 & 0.0 & 0.0 \\ 0.0 & 0.0 & 0.0 \\ 0 & & \end{array}$

PU239
2263.1
844.8
921.6
921.6
921.6
921.6
921.6
921.6
921.6
921.6
921.6
921.6
921.6
921.6
921.6
921.6
921.6
901.1
881.9
861.44
840.9
820.5
801.3
780.8
760.3
741.1
720.6
700.1
679.7
660.5
640.0

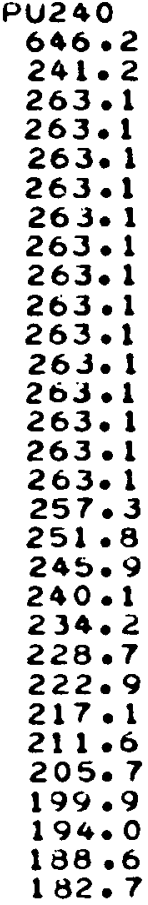

PU2 21
340.5
127.1
138.6
138.6
138.6
138.6
138.6
138.6
138.6
138.6
138.6
138.6
138.6
138.6
138.6
138.6
135.6
132.7
129.6
126.5
123.4
120.5
117.5
114.4
1111.5
1108.4
105.3
102.3
99.4
96.3
9

$P U 242$
114.7
$42 \cdot 8$
46.7
46.7
46.7
46.7
46.7
46.7
46.7
46.7
46.7
46.7
45.7
46.7
46.7
46.7
45.6
44.7
43.6
42.6
41.6
40.6
39.6
38.5
37.5
36.5
35.5
34.4
33.5
32.4

FISSILE TOTAL PU
2603.6
971.57256 .8 $971.9 \quad 15731 \cdot 3$ 1060.217161 .4 $1060.2 \quad 17161.4$ 1060.217161 .4 1060.217161 .4 1060.217161 .4 1060.217101 .4 $1060.2 \quad 17161.4$ $1060.2 \quad 17161.4$ $1060.2 \quad 17161.4$ 1060.217161 .4 1060.217161 .4 $1060.2 \quad 17161.4$ $\begin{array}{ll}1060.2 & 17161.4 \\ 1060.2 & 17161.4\end{array}$ $1036.7 \quad 16780.0$ $1014.6 \quad 16422.5$ $991.0 \quad 16041.1$ 967.515659 .8 $943.9 \quad 15278.4$ 921.814920 .9 $898.3 \quad 14539.5$ $874.7 \quad 14158.1$ $852.6 \quad 13800.6$ $\begin{array}{ll}852.6 & 13800 \cdot 6 \\ 829.0 & 13419.3\end{array}$ $805.5 \quad 13037.9$ $761.9 \quad 12650.5$ $\begin{array}{ll}759.8 & 12295.0 \\ 736.3 & 11917.0\end{array}$ 
Table 3.14

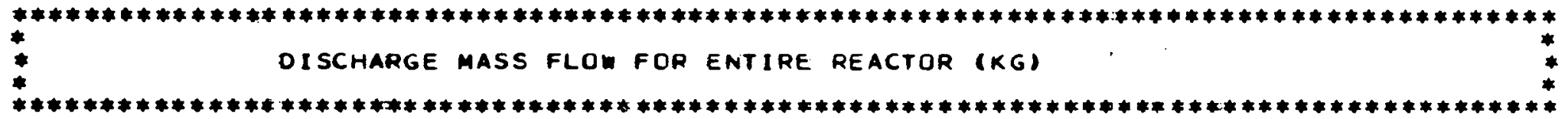

REACTOR IDENTIFICATION: PUTTH/TH LMFBR O 1200 MWE (RZ MODEL) CAPACITY

\begin{tabular}{|c|c|c|c|}
\hline $\begin{array}{l}E A R \\
1 \\
2 \\
3 \\
4 \\
5 \\
6 \\
7 \\
8 \\
9 \\
10 \\
11 \\
12 \\
13 \\
14 \\
15 \\
16 \\
17 \\
18 \\
19 \\
20 \\
21 \\
22 \\
23 \\
24 \\
25 \\
26 \\
27 \\
28 \\
29\end{array}$ & $\begin{array}{l}\text { FACTOR } \\
0.600 C \\
0.6600 \\
0.7200 \\
0.7200 \\
0.7200 \\
0.7200 \\
0.7200 \\
0.7200 \\
0.7200 \\
0.7200 \\
0.7200 \\
0.7200 \\
0.7200 \\
0.7200 \\
0.7200 \\
0.7200 \\
0.7040 \\
0.6890 \\
0.6730 \\
0.6570 \\
0.6410 \\
0.6260 \\
0.6100 \\
0.5590 \\
0.5790 \\
0.5630 \\
0.5470 \\
0.5310 \\
0.55160 \\
0.5000\end{array}$ & $\begin{array}{l}\text { TH2J2 } \\
12932 \cdot 1 \\
13910 \cdot 9 \\
14885 \cdot 4 \\
14854 \cdot 8 \\
14826.1 \\
14796.8 \\
14798 \cdot 6 \\
14797 \cdot 7 \\
14796.4 \\
14795 \cdot 9 \\
14795.6 \\
14795.6 \\
14795.6 \\
14795.6 \\
14795.6 \\
14795.6 \\
14466.8 \\
14158.6 \\
13829.8 \\
13501.0 \\
13172.2 \\
12864.0 \\
12535.2 \\
12206.4 \\
11898.1 \\
11569.3 \\
11240.6 \\
10911.8 \\
10603.5 \\
43255.0\end{array}$ & $\begin{array}{l}4233 \\
227.2 \\
422.2 \\
599.4 \\
622.0\end{array}$ \\
\hline
\end{tabular}

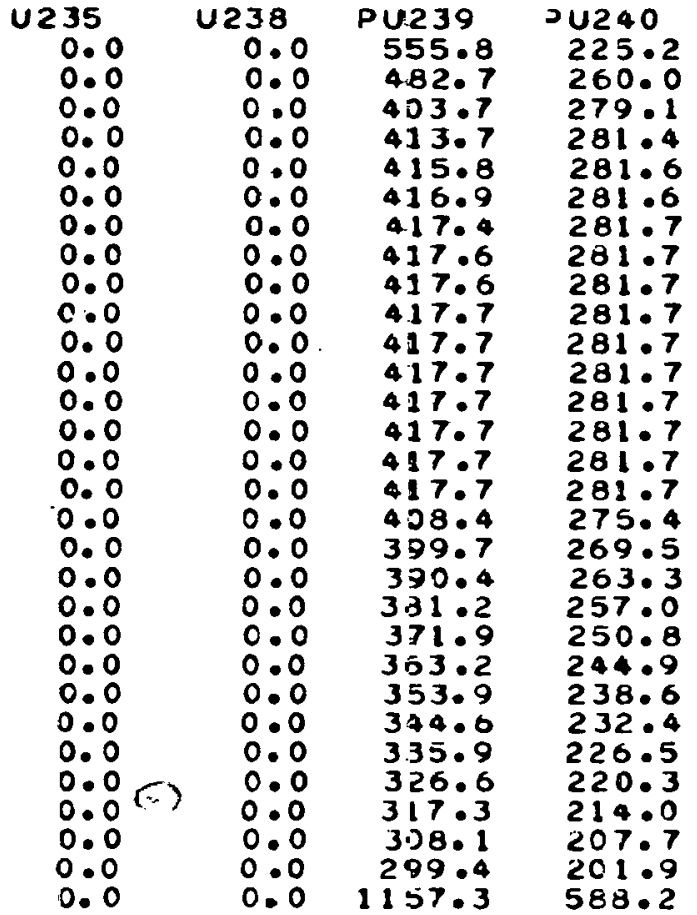

$P$
64.1
85.9
79.6
73.3
74.5
74.6
74.7
74.8
74.8
74.8
74.9
74.8
74.8
74.8
74.8
74.8
74.8
73.1
71.6
69.9
69.2
65.6
65.0
63.4
61.7
61.1
55.5
5.5 .8
55.2
53.6
84.8

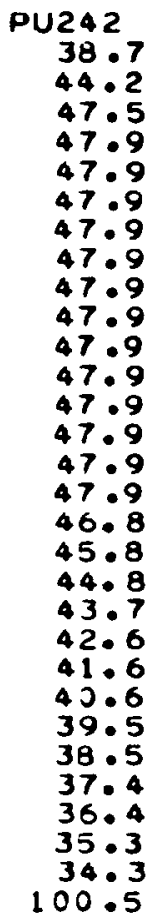

ZONES)

FISSILE TOTAL

$641.7 \quad 14064.9$

$641.7 \quad 14064.9$

$562 \cdot 3 \quad 15197.5$

477.016288 .4

$488.2 \quad 16294.3$

$490.4 \quad 16292 \cdot 3$

$491.6 \quad 16287.4$

$492.2 \quad 16284.0$

$492.4 \quad 16289.2$

$492.4 \quad 16283.9$

$492.5 \quad 16288.8$

$492.5 \quad 16288.8$

492.516288 .8

$492.5 \quad 16288.8$

492.516289 .8

$492.5 \quad 16284.8$

$492.5 \quad 16288.8$

481.515926 .8

$471.3 \quad 15587.4$

$400.3 \quad 15225.5$

$40.3 \quad 15225.5$

$449.4 \quad 14863.5$

438.4

$428 \cdot 2$

$417 \cdot 2$

$14501 \cdot 5$

14162.2

406.313438 .2

396.013098 .9

$385.1 \quad 12736.5$

374.212374 .9

363.212013 .0

$352.9 \quad 11073.0$
$1346.1 \quad 46503.0$ 
Table 3.15

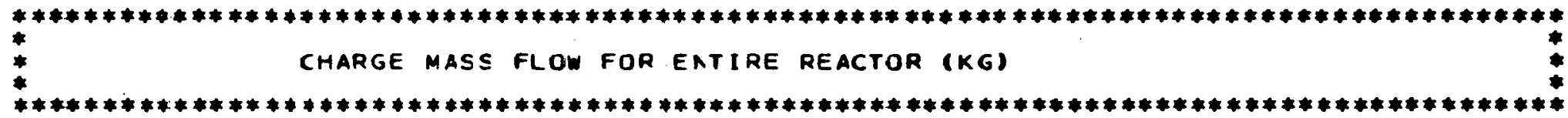

REACTOR IDENTIFICATION

PU-U/UTTH LMFBR O 1200 MWE (RZ MODEL) PU/UO2 CORE, UD2 AXIAL BLANKETS.THO2 RADIAL BLANKET (2 CORE ZONES)

$\begin{array}{ccc}\text { CAPACITY } \\ \text { YEAR FACTOR } & \text { TH232 } \\ 1 & 0.6000 & 28082.2 \\ 2 & 0.6600 & 5149.4 \\ 3 & 0.7200 & 5616.4 \\ 4 & 0.7200 & 5616.4 \\ 5 & 0.7200 & 5616.4 \\ 6 & 0.7200 & 5616.4 \\ 7 & 0.7200 & 5616.4 \\ 8 & 0.7200 & 5616.4 \\ 9 & 0.7200 & 5616.4 \\ 10 & 0.7200 & 5616.4 \\ 11 & 0.7200 & 5616.4 \\ 12 & 0.7200 & 5616.4 \\ 13 & 0.7200 & 5616.4 \\ 14 & 0.7200 & 5616.4 \\ 15 & 0.7200 & 5616.4 \\ 16 & 0.7200 & 5616.4 \\ 17 & 0.7040 & 5491.6 \\ 18 & 0.6890 & 5374.6 \\ 19 & 0.6730 & 5249.8 \\ 20 & 0.6570 & 5125.0 \\ 21 & 0.6410 & 5000.2 \\ 22 & 0.6260 & 4883.2 \\ 23 & 0.6100 & 4758.4 \\ 24 & 0.5940 & 4633.6 \\ 25 & 0.5790 & 4516.6 \\ 26 & 0.5630 & 4391.7 \\ 27 & 0.5470 & 4266.9 \\ 28 & 0.5310 & 4142.1 \\ 29 & 0.5160 & 4025.1 \\ 30 & 0.5000 & 3900.1 \\ & & \end{array}$

\begin{tabular}{|c|}
\hline $\begin{array}{l}33 \\
0.0 \\
0.0 \\
0.0 \\
0.0 \\
0.0 \\
0.0 \\
0.0 \\
0.0 \\
0.0 \\
0.0 \\
0.0 \\
0.0 \\
0.0 \\
0.0 \\
0.0 \\
0.0 \\
0.0 \\
0.0 \\
0.0 \\
0 . c \\
0.0 \\
0 . c \\
0.0 \\
0.0 \\
0.0 \\
0.0 \\
0.0 \\
0.0 \\
0.0 \\
0.0\end{array}$ \\
\hline
\end{tabular}

\begin{tabular}{|c|c|}
\hline 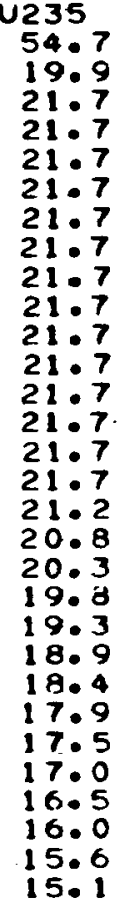 & 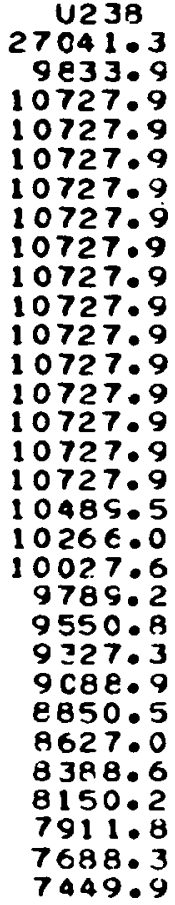 \\
\hline
\end{tabular}

$9 \cup 239$
1909.6
734.0
800.7
800.7
800.7
800.7
800.7
800.7
800.7
800.7
800.7
800.7
800.7
800.7
800.7
800.7
732.9
766.2
748.4
730.6
712.8
696.2
678.4
660.6
643.9
626.1
608.3
590.5
573.8
556.0

$\begin{array}{ll}\text { PU240 } & \text { PU241 } \\ 547.6 & 290.0 \\ 216.4 & 114.6 \\ 236.1 & 125.0 \\ 236.1 & 125.1 \\ 236.1 & 125.0 \\ 236.1 & 125.0 \\ 236.1 & 125.1 \\ 236.1 & 125.1 \\ 236.1 & 125.1 \\ 236.1 & 125.1 \\ 236.1 & 125.1 \\ 236.1 & 125.1 \\ 236.1 & 125.1 \\ 236.1 & 125.0 \\ 236.1 & 125.0 \\ 236.1 & 125.1 \\ 230.9 & 122.3 \\ 225.9 & 119.6 \\ 220.7 & 116.9 \\ 215.4 & 114.1 \\ 210.2 & 111.3 \\ 205.3 & 118.7 \\ 200.0 & 105.9 \\ 194.8 & 103.1 \\ 189.9 & 100.5 \\ 184.6 & 97.8 \\ 179.4 & 95.0 \\ 174.1 & 92.2 \\ 169.2 & 89.6 \\ 164.0 & 86.8\end{array}$

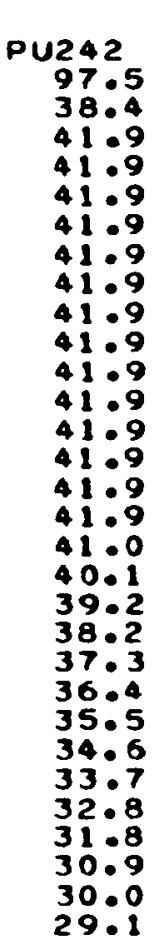

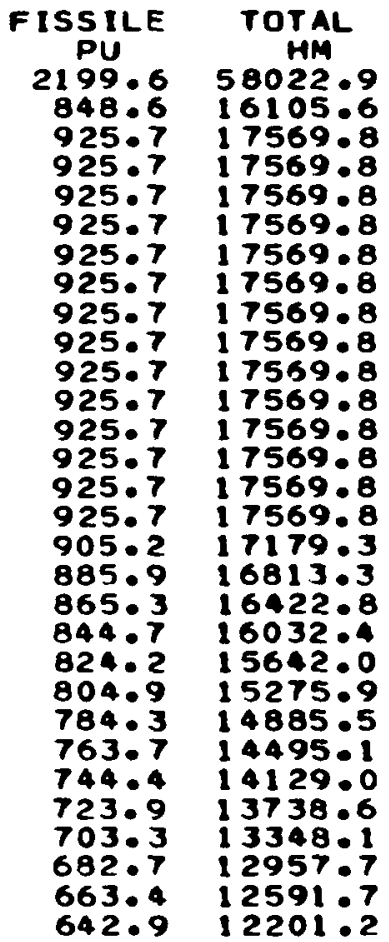




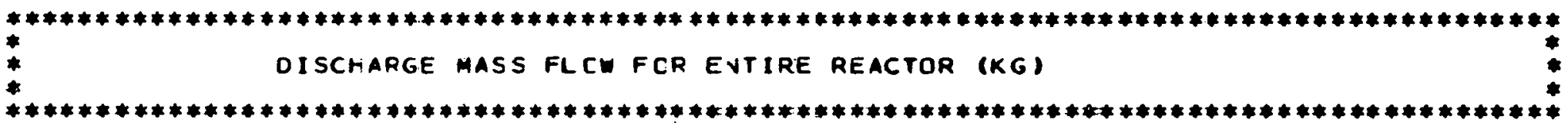

REACTOR ICENTIFICATION: PU-U/U-THLMFBR D 1200 MWE (RR MODEL)

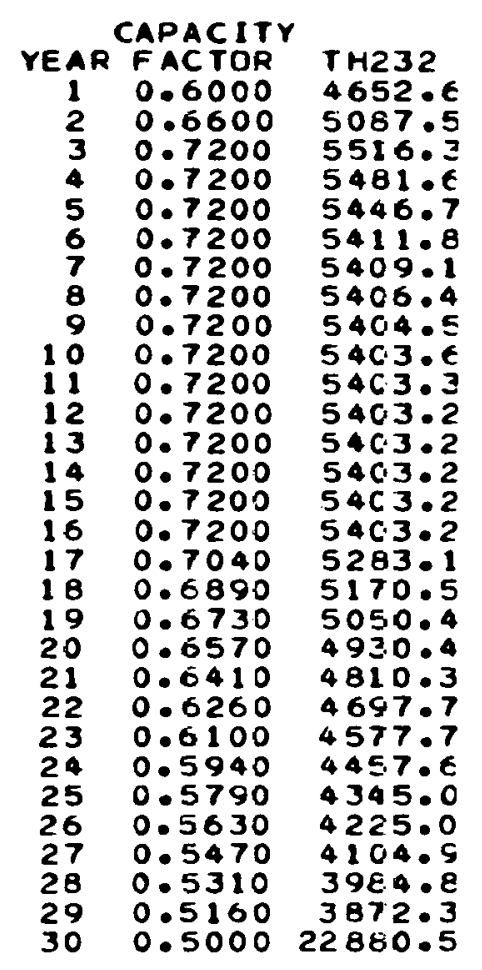

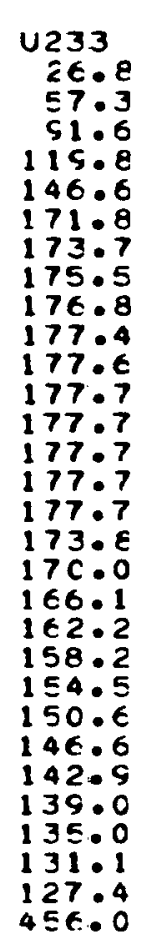

\begin{tabular}{|c|c|}
\hline 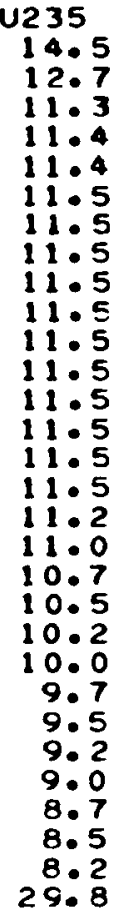 & $\begin{array}{r}\text { U238 } \\
8807 \\
9302 . \\
9834 . \\
9 E 13 . \\
9818\end{array}$ \\
\hline
\end{tabular}

\begin{tabular}{|c|}
\hline $\begin{array}{l}893.4 \\
893.5 \\
893.3 \\
892.8 \\
892.5 \\
892.4 \\
832.4 \\
832.4 \\
832.4 \\
832.4 \\
892.4 \\
832.4 \\
832.4 \\
832.4 \\
872.5 \\
853.9 \\
334.1 \\
814.3 \\
734.4 \\
775.9 \\
756.0 \\
736.2 \\
717.6 \\
697.8 \\
677.9 \\
658.1 \\
639.5 \\
1811.4\end{array}$ \\
\hline
\end{tabular}

PU240

189.3

252.6

301.3

304.5

304.2

303.6

303.5

303.4

303.4

303.4

303.4

303.4

303.4

303.4

303.4

296.7

290.4

283.6

270.1

263.8

257.1

250.3

244.0

237.3

230.5

223.8

217.5
587.8

PU241
68.5
68.8
66.5
68.3
68.3
68.4
68.4
68.4
68.4
68.4
68.4
68.4
68.4
68.4
68.4
68.4
66.9
65.5
64.0
62.4
60.9
59.5
58.0
56.5
55.0
53.5
52.0
50.5
49.0
169.5

(6/09/77)
CORE ZONES 
Table 3.17

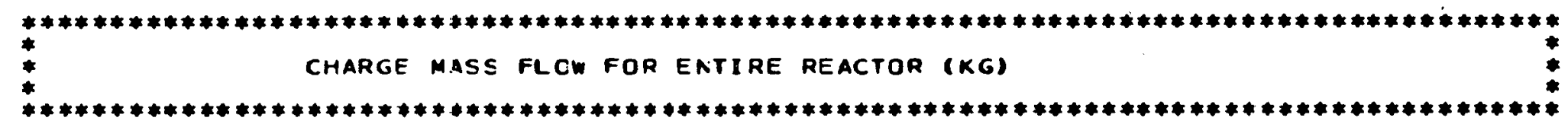

REACTOR IDENTIFICATION: U233-TH/TH LMFBR D 1200 MWE (RZ MODEL'

( 2 CORE (6ONEST)

CAPACITY

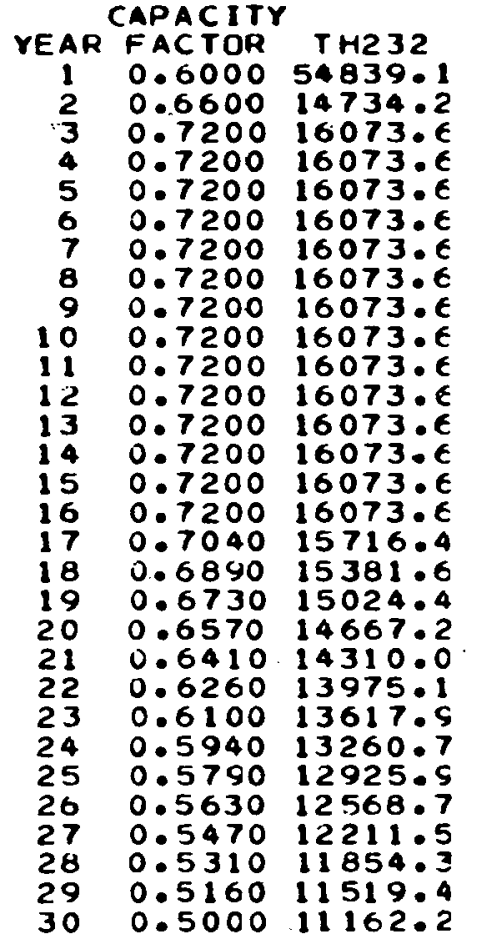

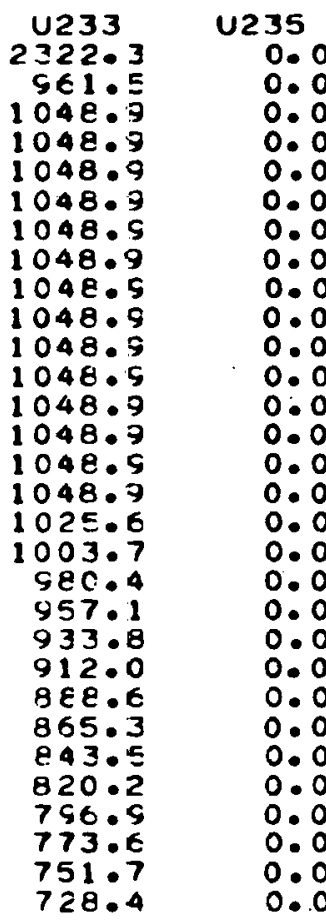

238
0.0
0.0
0.0
0.0
0.0
0.0
0.0
0.0
0.0
0.0
0.0
0.0
0.0
0.0
0.0
0.0
0.0
0.0
0.0
0.0
0.0
0.0
0.0
0.0
0.0
0.0
.0 .0
0.0
0.0
0.0

Pu2 39
0.0
0.0
0.0
0.0
0.0
0.0
0.0
0.0
0.0
0.0
0.0
0.0
0.0
0.0
0.0
0.0
0.0
0.0
0.0
0.0
0.0
0.0
0.0
0.0
0.0
0.0
0.0
0.0
0.0

$P \cup 240$
0.0
0.0
0.0
0.0
0.0
0.0
0.0
0.0
0.0
0.0
0.0
0.0
0.0
0.0
0.0
0.0
0.0
0.0
0.0
0.0
0.0
0.0
0.0
0.0
0.0
0.0
0.0
0.0
0.0
0.0
0.0

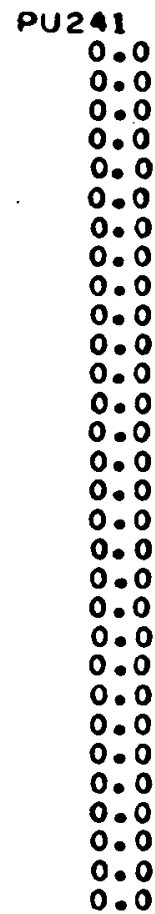

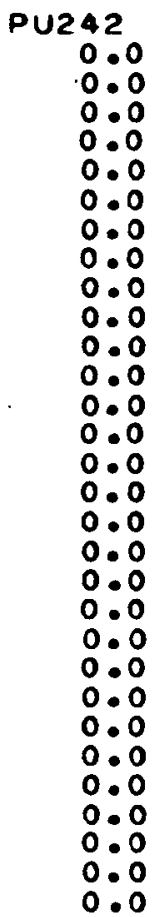

FISSILE TOTAL

\begin{tabular}{ll} 
SSILE & \multicolumn{1}{c}{ TOTAL } \\
PU & HM \\
0.0 & $57161 \cdot 4$ \\
0.0 & 15695.6 \\
0.0 & $17122 \cdot 5$ \\
0.0 & 17122.5 \\
0.0 & 17122.5 \\
0.0 & 17122.5 \\
0.0 & 17122.5 \\
0.0 & 17122.5 \\
0.0 & 17122.5 \\
0.0 & 17122.5 \\
0.0 & 17122.5 \\
0.0 & 17122.5 \\
0.0 & 17122.5 \\
0.0 & 17122.5 \\
0.0 & 17122.5 \\
0.0 & 17122.5 \\
0.0 & 16742.0 \\
0.0 & 16385.3 \\
0.0 & 16004.8 \\
0.0 & 15624.3 \\
0.0 & 15243.8 \\
0.0 & 14887.1 \\
0.0 & 14506.6 \\
0.0 & 14126.1 \\
0.0 & 13769.4 \\
0.0 & 13388.9 \\
0.0 & $13008 \cdot 4$ \\
0.0 & 12627.9 \\
0.0 & 12271.1 \\
0.0 & 11890.6
\end{tabular}


Table 3.18

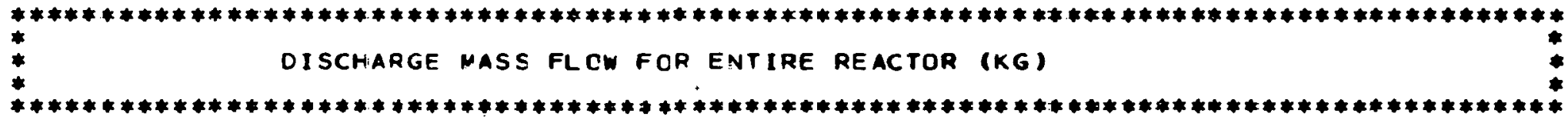

REACTOR IDENTIFICATICN: UZ33-TH/TH LMFBR a 1200 MWE (RZ MJOEL) U233/THO2 CORE.THOZ AKIAL AND RADIAL BLANKETS (2 CORE ZONES)

CAPACITY

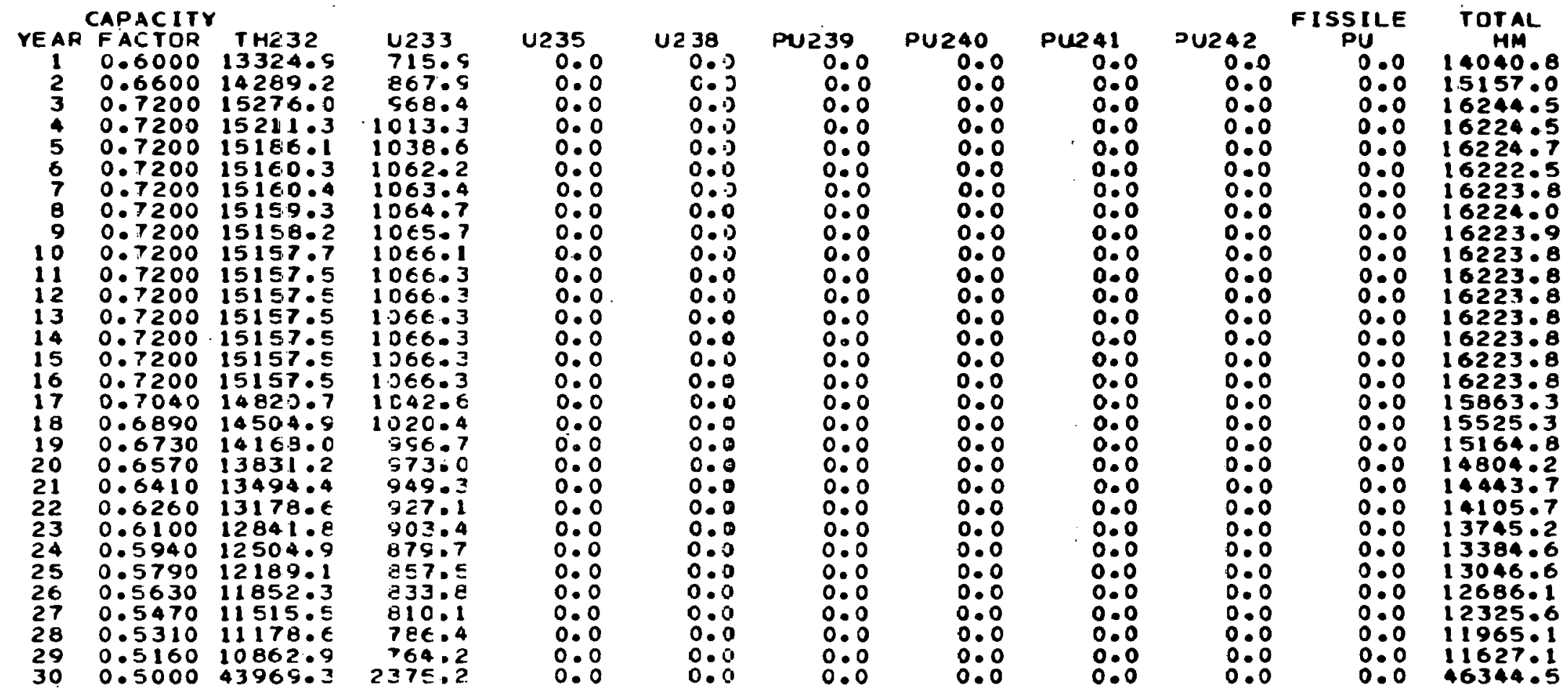




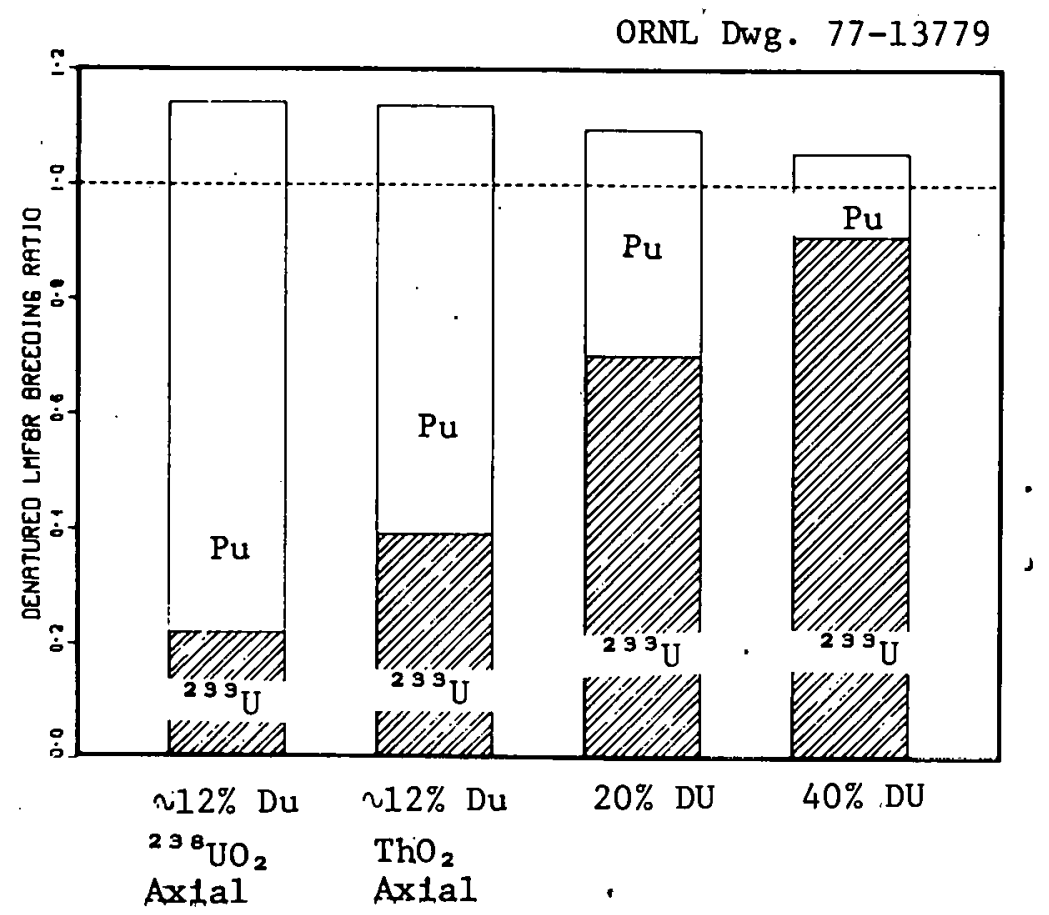

Fig. 3.1. Breeding ratio isotopes composition for various denatured reactors.

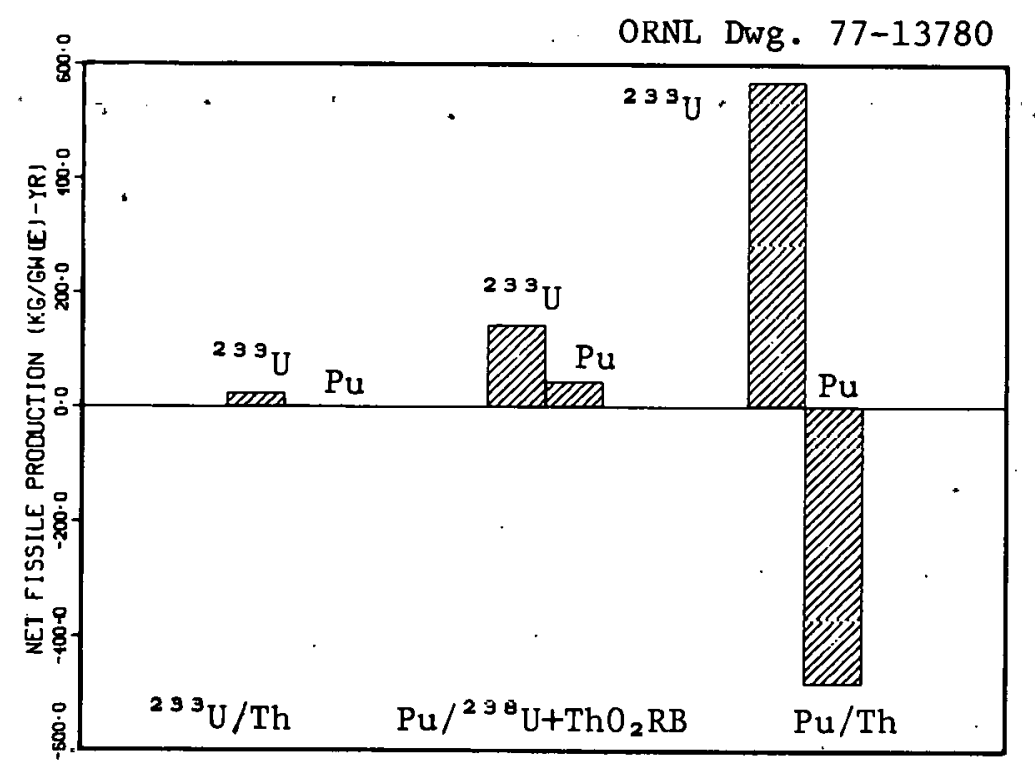

Fig. 3.2. Net fissile production for various energy center "transmuters . " 
center "transmuters." Since two fissile species are involved in the symbiotic relationship, a "window" of allowable outside/inside ratios is present. The symbiotic power ratio is constrained by $23{ }^{3} U$ production on one side and by $\mathrm{Pu}$ production on the other. One interesting aspect of the symbiosis is the existence of an asymptotic value of the outside/ inside power, ratio. Assuming that the inventory of each fissile isotope Is compounded annually (in a manner similar to that used to calculate a reactor's compound doubling time), the time dependent behavior of the symbiotic power ratio can be determined. Figure 3.3 illustrates the behavior for the two extreme initial values of the power ratio (no denatured reactors and the maximum number which can be maintained by the transmuter) for one such system. As Fig. 3.3 indicates, the asymptotic value is approached regardless of the starting configuration. The asymptotic value is also the point where the growth rates of the two fissile inventories are identical. Hence, each component of the system (i.e., dispersed reactors and centralized reactors) is growing at the same rate, and a compound symbiotic system doubling time can be determined for this value of the power ratio. The doubling time can be determined by considering either fissile inventory, i.e.,

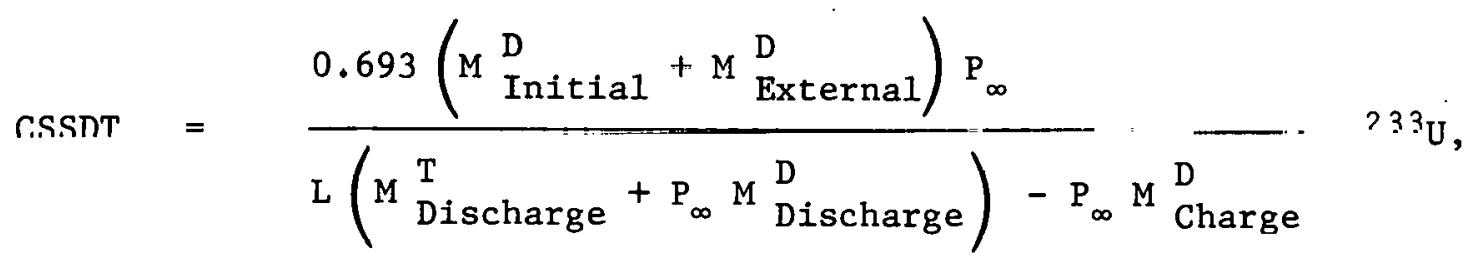

$$
\begin{aligned}
& =\frac{0.693\left(\mathrm{M}_{\text {Initial }}^{\mathrm{T}}+\mathrm{M}_{\text {External }}^{\mathrm{T}}\right)}{\mathrm{L}\left(\mathrm{M}_{\text {Discharge }}^{\mathrm{T}}+\mathrm{P}_{\infty} \mathrm{M} \frac{\mathrm{D}}{\text { Discharge }}\right)-\mathrm{M}} \underset{\text { Charge }}{\mathrm{T}} \quad \mathrm{Pu},
\end{aligned}
$$




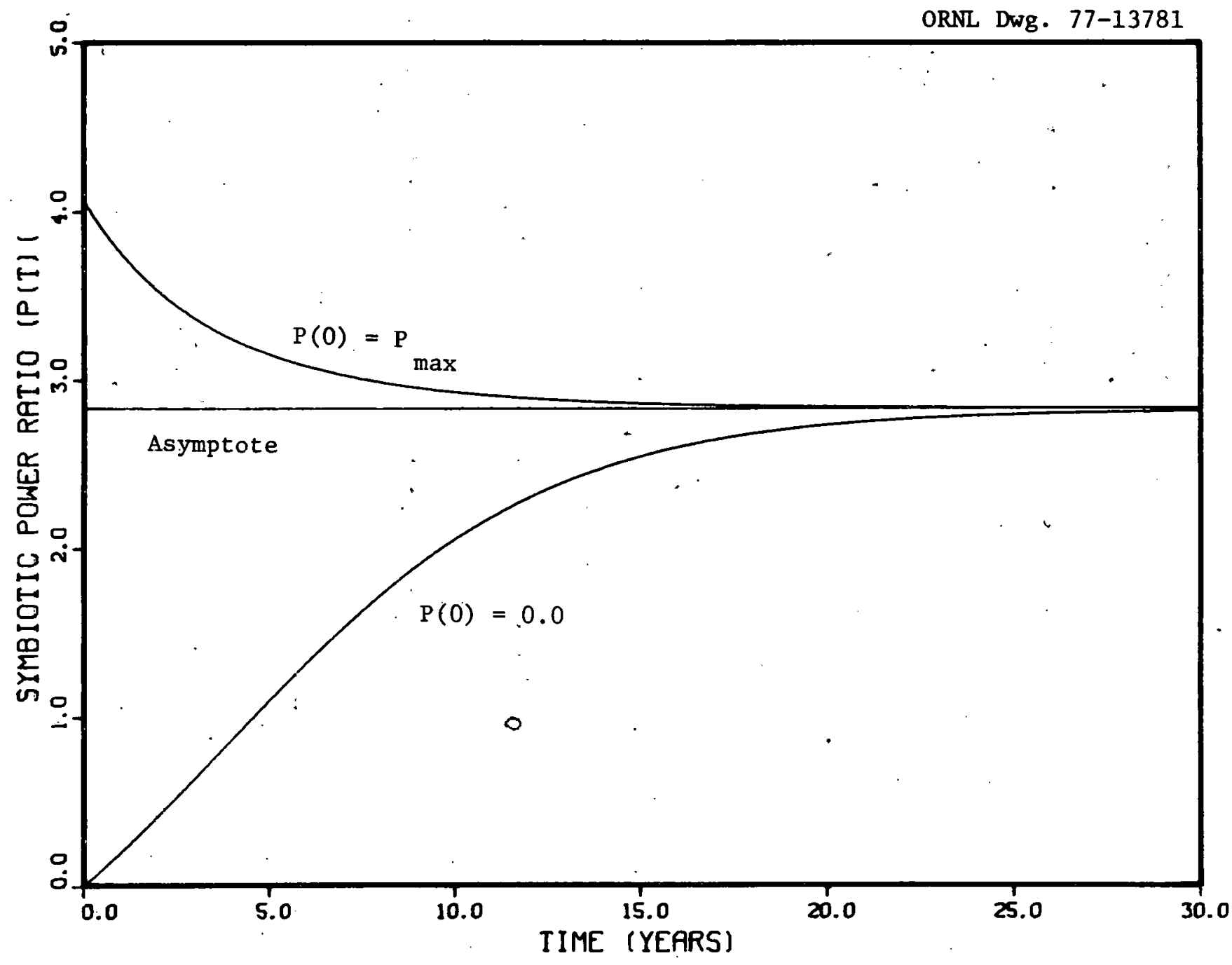

Fig. 3.3. Symbiotic power ratio for system of $20 \%$ denatured LMFBR's and energy center $\mathrm{Pu} / \mathrm{Th}$ transmuters (2\% fuel cycle losses, 1 year out of reactor time). 
where the superscripts indicate the type of reactor (Denatured or Transmuter), $\mathrm{P}_{\infty}$ is the asymptotic power ratio and $\mathrm{L}$ is a loss factor. Table 3.19 indicates the various symbiotic system parameters for a variety of transmuter and dispersed reactor combinations $(L=0.98 ; 1$ year out of reactor time). Also indicated are the corresponding values for a reference $\left(\mathrm{Pu} / 2{ }^{38} \mathrm{U}\right) \mathrm{O}_{2}$ system operating with no fuel cycle restrictions. As the values given in Table 3.19 indicate, maximizing the outside/inside ratio adversely effects the system doubling time. Similarly minimizing the system doubling time would adversely impact the symblotic power ratio. As expected, the systems based on the $\mathrm{Pu} /{ }^{238} \mathrm{U}+\mathrm{ThO}_{2} \mathrm{RB}$ reactor have shorter doubling times than the corresponding system based on the $\mathrm{Pu} / \mathrm{Th}$ LMFBR, reflecting the lower overall fissile production of the latter. Conversely, the power ratio of the systems based on the Pu/Th LMFBR are significantly better than those attained by the $\mathrm{Pu} / 238 \mathrm{U}+\mathrm{ThO}_{2} \mathrm{RB}$, reflecting the much higher ${ }^{233} \mathrm{U}$ production. For a given transmuter, increasing the denaturing constraint (i.e., decreasing the ${ }^{238} U$ and increasing the Th) increases the symbiotic power ratio (due to the lower ${ }^{23} 3 \mathrm{U}$ makeup requirements) and also increases the doubling time (due to the lower overall system fissile production).

\subsection{Cross-Section Sensitivity}

A primary concern in assessing various parameters pertaining to alternate fuel cycles is the adequacy of the nuclear data, especially when a detailed design/optimization effort is envisioned. Of particular concern is the ${ }^{232} \mathrm{Th}$ capture cross-section due to the use of ${ }^{23}{ }^{3} \mathrm{U}$ as fuel in the proposed denatured reactors. Recent measurements ${ }^{5}$ of the ${ }^{232} \mathrm{Th}$ 
Table 3.19. Equilibrium cycle symbiotic parameters ( $2 \%$ losses, 1 year out-of-reactor time)

\begin{tabular}{|c|c|c|c|}
\hline $\begin{array}{l}\text { Energy Center } \\
\text { Reactor LMFBR }\end{array}$ & $\begin{array}{c}\text { Dispersed } \\
\text { LMFBR }\end{array}$ & $\begin{array}{c}\text { Asymptotic } \\
\text { Dispersed } \\
\text { Outside/Energy Center } \\
\text { Power Ratio }\end{array}$ & $\begin{array}{l}\text { Compound } \\
\text { System } \\
\text { Doubling } \\
\text { Time (Years) }\end{array}$ \\
\hline$(\mathrm{Pu} / \mathrm{U}) \mathrm{O}_{2}+\mathrm{ThO}_{2} \mathrm{RB}$ & $\sim 12 \%$ Denatured & 0.35 & 14.3 \\
\hline$(\mathrm{Pu} / \mathrm{U}) \mathrm{O}_{2}+\mathrm{ThO}_{2} \mathrm{RB}$ & $20 \%$ Denatured & 0.52 & 16.5 \\
\hline$(\mathrm{Pu} / \mathrm{U}) \mathrm{O}_{2}+\mathrm{ThO}_{2} \mathrm{RB}$ & $40 \%$ Denatured & 0.94 & 21.9 \\
\hline $\mathrm{Pu} / \mathrm{Th}$ & $\sim 12 \%$ Denatured & 1.67 & 24.7 \\
\hline $\mathrm{Pu} / \mathrm{Th}$ & $20 \%$ Denatured & 2.83 & 33.8 \\
\hline $\mathrm{Pu} / \mathrm{Th}$ & $40 \%$ Denatured & 6.91 & 66.0 \\
\hline - & $(\mathrm{Pu} / \mathrm{U}) \mathrm{O}_{2}$ & $\infty$ & 11.8 \\
\hline
\end{tabular}

Table 3.20. Effect of revised ${ }^{232} \mathrm{Th}$ capture cross sections

\begin{tabular}{lcc}
\hline & ENDF/B-IV & $\begin{array}{c}\text { Revised } \\
\text { Th Capture }\end{array}$ \\
\hline 20\% Denatured & & \\
Initial Inventory [KG/GW(e)] & 2192 & 2050 \\
Equilibrium Reload [KG/GW(e)] & 813 & 796 \\
Breeding Ratio & 1.096 & 1.050 \\
Pu/Th "Transmuter" & & \\
Initial Inventory [KG/GW(e)] & 2517 & 2280 \\
Equilibrium Reload [KG/GW(e)] & 894 & 865 \\
Breeding Ratio & 1.158 & 1.078 \\
Symbiotic Power Ratio & 2.83 & 2.59 \\
Compound System Doubling Time & 33.8 & 89.7 \\
(years) & & \\
Nuclear Energy Growth (\%/year) & 2.1 & 0.8 \\
\hline
\end{tabular}


capture cross section indicate marked differences from that derived from ENDF/B-IV in the region between $4 \mathrm{KeV}$ and $800 \mathrm{KeV}$ (ranging up to a $25 \%$ decrease). To assess the possible impact of a decrease of this magnitude, the $20 \%$ denatured LMFBR and the Pu/Th LMFBR were recalculated using a cross-section library adjusted for the decreased ${ }^{232}$ Th capture. The results are given in Table 3.20. The lower ${ }^{232} \mathrm{Th}$ capture results in slightly smaller fissile inventories in both reactors and, more significantly, markedly reduces the breeding ratio (breeding gain) in both systems. The asymptotic power ratio is essentially unchanged since the percentage decrease in the breeding gain in each reactor is comparable. The revised ${ }^{232}$ Th capture data does effect the symbiotic system doubling time, increasing it by a factor of 2.65. Although the lower ${ }^{232} \mathrm{Th}$ cross section can possibly be compensated for by increasing the fertile loading, it is evident that, in view of the large uncertainties in the nuclear data, all alternate fuel cycle results should be regarded as scoping calculations pending measurement and/or reevaluation of the pertinent nuclear data. 
4. ADVANCED LMFBR SYSTEMS

D. L. Selby

\subsection{General Considerations}

In addition to the $\mathrm{Th}_{2}$ base fuels there are two major thorium systems under consideration as fuels for fast reactor systems. These two systems are the Th base metal alloys and the Th carbide base fuels. It appears that both systems offer both advantages and disadvantages over the $\mathrm{ThO}_{2}$ fuels.

\subsection{Thorium Base Metal Fuels}

In general Th base metal fuels are characterized by high breeding ratios (relative to $\mathrm{Th}_{2}$ ), high thermal conductivity, negative sodium voiding coefficient, Doppler similar to oxide cores, and an energy spectrum much higher than equivalent oxide systems. Several Th alloys have been considered as fuels for fast breeder reactors. The most noted ones are:

1. $\mathrm{Th}-\mathrm{Pu}$

2. $T h-U$

3. $\mathrm{Th}-\mathrm{U}-\mathrm{Pu}$

The Th-Pu alloy fuel exhibits a very high breeding ratio (relative to oxide systems). Unfortunately, the metalurgical properties of this alloy eliminate it as a potential fuel for fast reactors. Above $450^{\circ} \mathrm{C}$ Pu-Th alloys with at least $10 \% \mathrm{Pu}$ have been found to undergo severe swelling. ${ }^{6}$ A Th-Pu alloy containing 15 wt \% plutonium increased in volume by $14 \%$ when irradiated at $500^{\circ} \mathrm{C}$ to .54 atom percent burnup. 
In order to take advantage of the resistance to swelling under irradiation exhibited by Th metal, it has been found that the $U$ content of the U-Th alloy must not exceed $25 \%$ by weight. $7,8,9$ Above $25 \%$ by wt $\mathrm{U}$ Th-U, alloys irradiated up to $700^{\circ} \mathrm{C}$ exhibited severe distortions and swellings up to $8 \% \Delta \mathrm{V}$ per atom percent burnup. Simple calculations for a Th-20\%wtU alloy have shown a relatively low breeding ratio. However, the breeding ratio is greatly affected by the amount of total cladding in the core. The use ot large tuei pins could decrease the amount of cladding needed and thus could increase the breeding ratio to as much as 1.35 .

It appears that the Th-U-Pu trinary represents the better of the three fuels considered. It has been shown that up to $10 \% \mathrm{U}$ in the $\mathrm{Th}-20 \% \mathrm{wt}$ $\mathrm{U}$ alloy can be replaced by $\mathrm{Pu}$ with little or no effect on the irradiation behavior. 0 Furthermore, the addition of the $\mathrm{Pu}$ substantially increases the breeding ratio. Preliminary calculations have shown that breeding ratios as high as 1.65 can be obtained depending on the fuel pin size.

\subsection{Thorium Base Carbide Fuels}

A lot less information is known about the carbide fuels than the metal tuels. Preliminary calculations have not been completed, but it appears that the breeding ratios obtained for the carbide fuels will be more similar to those obtained for the oxide fuels than those obtained for the metal fuels. 


\section{FLOW OF NUCLEAR MATERIAL FOR RESTRICTED \\ FUEL CYCLE SCENARIOS}

J. C. Cleveland

This report describes the flow of nuclear material for various restricted fuel cycle scenarios intended to alleviate safeguards concerns through the use of thorium fuel cycles. These scenarios, and the corresponding objectives for the safeguards related thorium assessment studies have been listed in an ORNL Quarterly Progress Report ${ }^{11}$ and are reported in Table 5.1.

The first fuel cycle to be considered, as is indicated in Table 5.1, is the throwaway cycle HTGR. The throwaway cycle would be required if reprocessing of spent reactor fuel is judged to lead to unacceptable proliferation risks and therefore not allowed. Based on information presented in Ref. 12, the HTGR fuel cycle which is optimized for throwaway conditions involves the use of fully enriched uranium in thorium. If security considerations prohibit the use of fully enriched uranium, the HTGR throwaway cycle would be a LEU ( 11 to $13 \%$ enriched uranium) cycle or a denatured $235 \mathrm{U}$-thorium cycle. Under no-reprocessing restrictions, no exogenous source of ${ }^{23}{ }^{3} \mathrm{U}$ would be available for denatured cycles.

A simplified diagram of this HTGR throwaway cycle scenario is given in Fig. 5.1. More detail concerning the fuel fabrication process is shown in Fig. 5.2. For the optimized throwaway cycle, highly enriched material would be handled throughout the fuel element fabrication process. ${ }^{13}$ The security problems would be reduced significantly if the throwaway cycle were a LEU cycle or a denatured cycle. 
Table 5.1. Suggeszed scenarios, objectives and criteria

for safeguarded-zelated thorium assessment studies

Restricted Fuel Cycle Scenarios

1. Throwaway Crcle - HTGR

2. Safeguarded repracessing and non-denatured cyzles with dispersed and denatured cycles.

a. All LWR symbiotic systen

b. LMFBR + LWR symbiotic systems

c. LMFBR, ETGR, HWR, LWR + LWR, HTGR, HNR symbiotic systems
Objectives

Criteria

1. Letermine effects of employing FTGR on power cost and fuel

resources nnder no-

zeprocessing conditions.

2. Create a spmbiotic system which woulc maxinize resource utilizarion and power dispersal for the reactor miz considered; deterIIine neutronic, capital cast, and safety implications.

a. For current, a11 LWR

t. Introdaction of the LMFBR

c. Introduction of HTGR, HWR.
1. Comparison of HTGR parameters with LWR parameters.

2. Create safeguarded nuclear fuel cycles which compete with coal over the long-term, and which are consistent with the nuclear fuel resource base. Maximize $\mathrm{U}_{23} 3$ component over $\mathrm{Pu}$ component. Maximize power production in dispersed reactors. 
ORNL-DWG-77-i7382

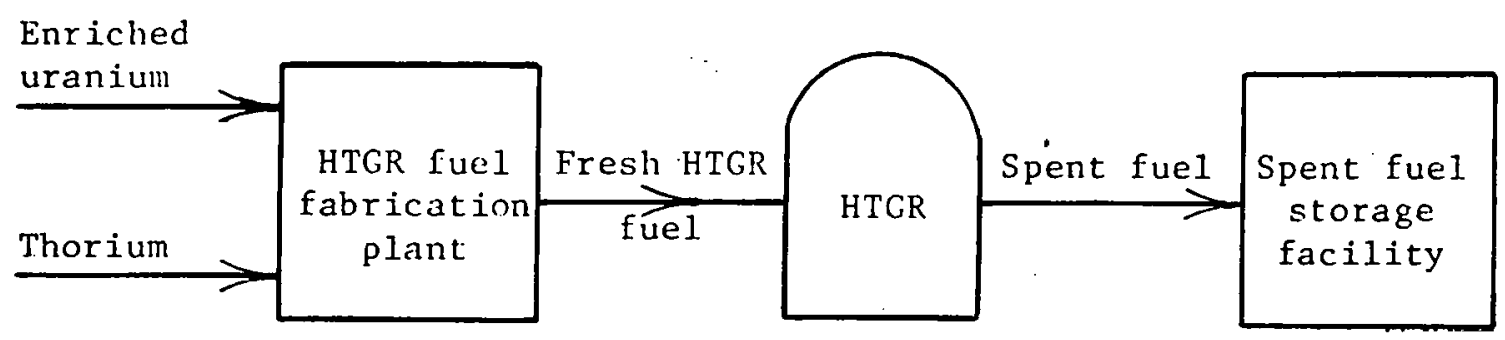

Fig. 5.1. HTGR throwaway cycle.

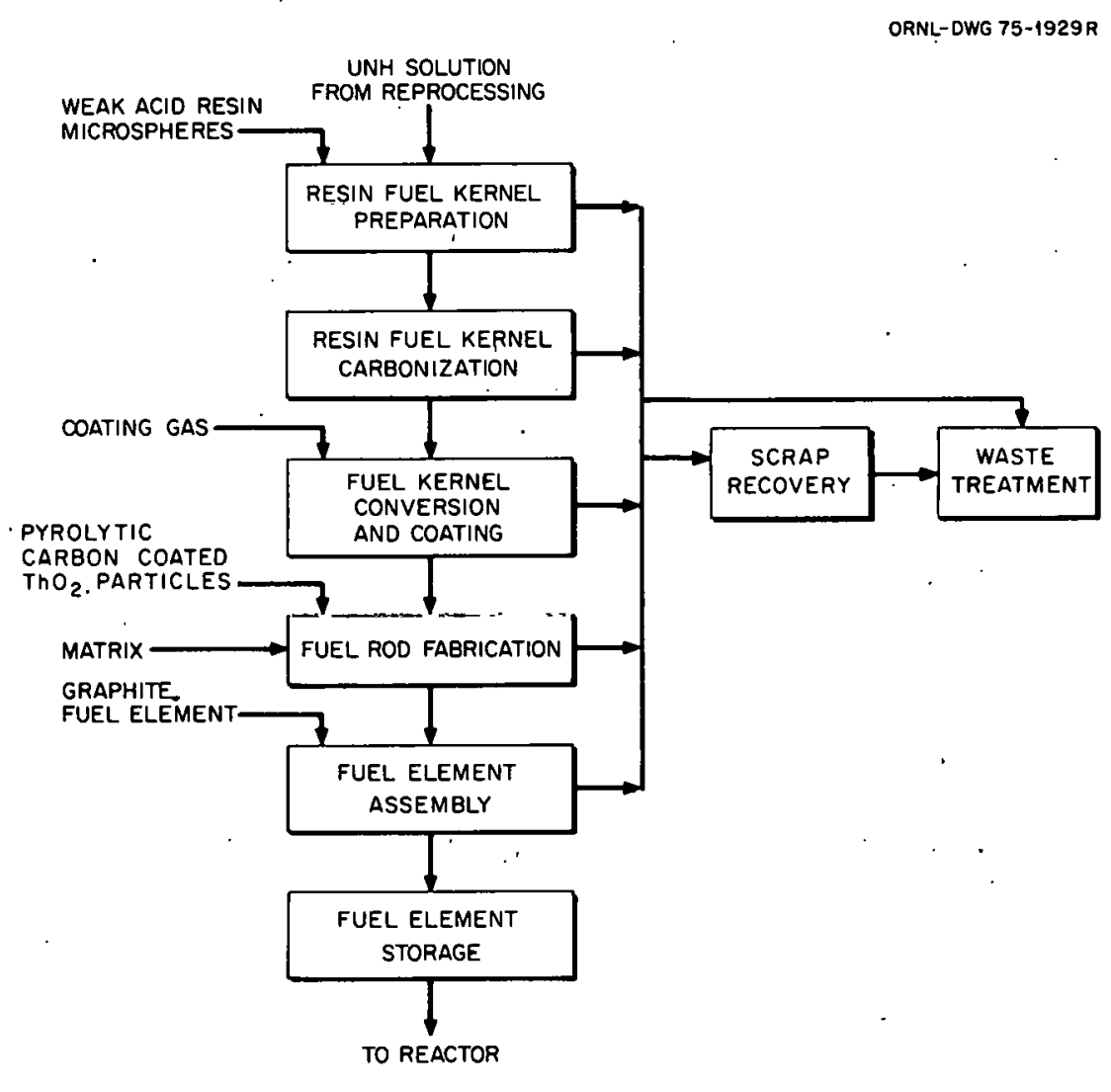

Fig. 5.2. Process for HTGR fuel element fabrication. 
The scenarios to be considered in which reprocessing of spent fuel is allowed involve the use of fuel cycle centers containing nondenatured reactors, fuel reprocessing, refabrication and waste management facilities. Within these centers, denatured fuel would be fabricated for use in the dispersed reactors.

The first of these scenarios, as 11sted in Table 5.1, is the all LWR symbiotic system. Under this scenario there can be two types of fuel for the dispersed reactors:

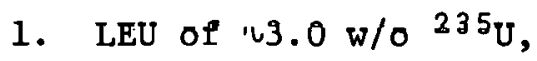

2. Denatured uranium in thorium.

The fuel composition involving ${ }^{23} 3 \mathrm{U}$ of $\mathrm{i} 2.5 \mathrm{w} / \mathrm{o}$ in ${ }^{238} \mathrm{U}$ with no thorlum component is not considered because of the preference to breed ${ }^{23} \mathrm{U}$ rather than plutonium. Within the secured area, the primary reactor fuel composition will be plutonium in throium. The conventional "mixed oxide" fuel composition involving plutonium in natural or depleted uranium will not be considered--again because of the preference to breed ${ }^{23}{ }^{3} \mathrm{U}$ rather than piutonilum. Ihe fuel composiclons 1nvolving fully enrlched ${ }^{235} \mathrm{U}$ In thorfum and nondenatured bred ${ }^{23} \mathrm{U}$ in thortum will also be considered as candidates for fueling reactors within the secured area. However, if this available ${ }^{235} \mathrm{U}$ and bred ${ }^{23.3} \mathrm{U}$ were denatured and used to fuel dispersed reactors, plutonium production in the total system would be somewhat increased, which is contrary to the objectives; but the ratio of dispersed reactors to secured reactors would be increased, which is an objective. The study will attempt to arrive at a reasonable trade-off. A simplified diagram for the flow of fuel in this all LWR symbiotic system is shown in Fig. 5.3. As shown, spent elements from the dispersed 


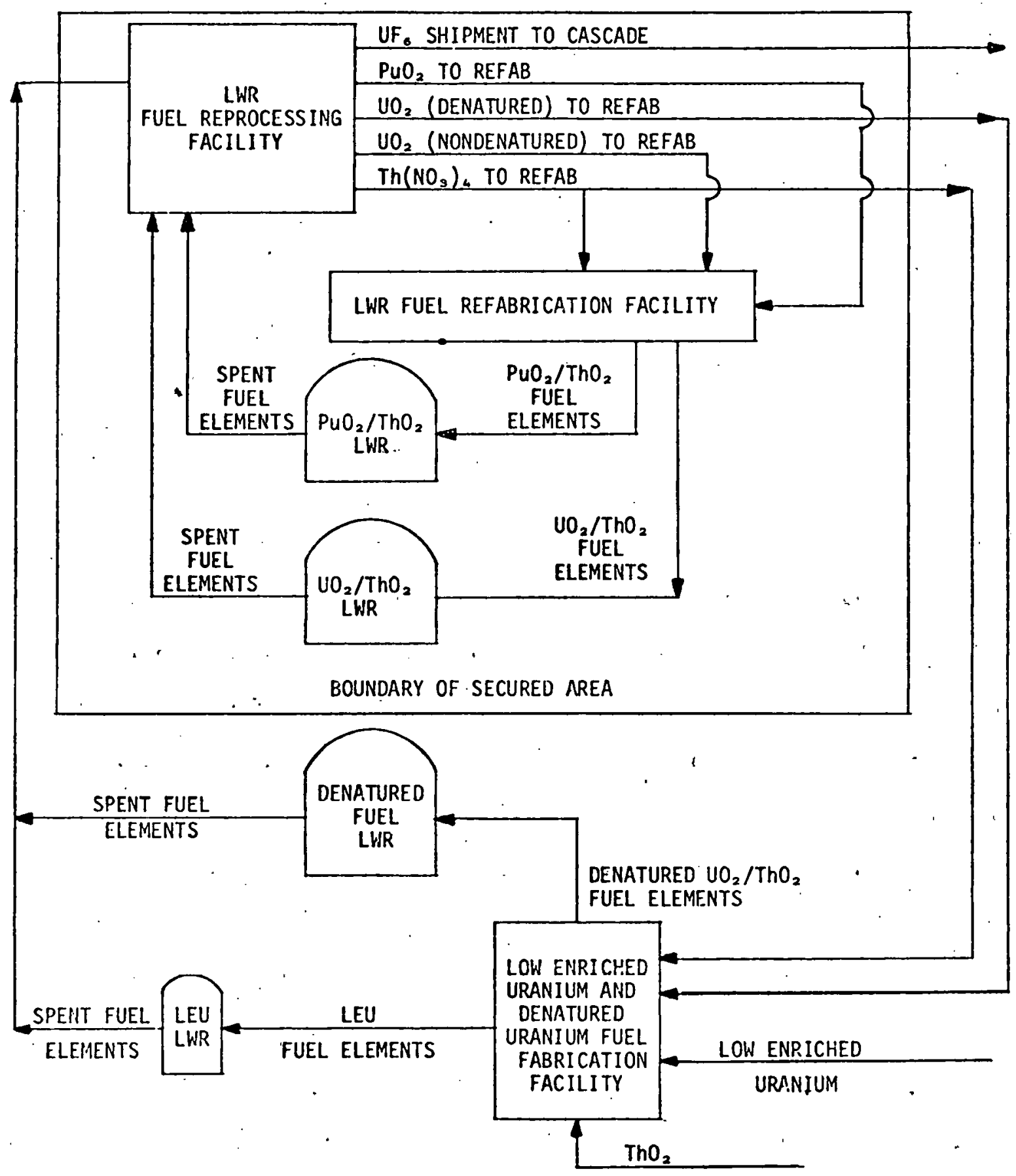

Fig. 5.3. Fuel flow schematic for LWR symbiotic system. 
reactors are shipped to the fuel cycle centers for reprocessing. Within the reprocessing plant, the uranium and plutonium are separated from the spent LEU fuel: the uranium being converted to $\mathrm{UF}_{6}$ for shipment to the cascade and the plutonium being sent as $\mathrm{PuO}_{2}$ to the fuel refabrication plant located within the fuel cycle center. Uranium separated from the denatured fuel would be re-enriched to the allowable limit by addition of fully enriched ${ }^{235} \mathrm{U}$ or, if avallable, by addition of bred ${ }^{23} \mathrm{U}$. Plutonium separated from the spent denatured fuel would also be sent to the fabrication facility. Within the secured area, the plutonium would be fabricated into $\mathrm{PuO}_{2} / \mathrm{ThO}_{2}$ fuel elements used to fuel LWRs within the secure area. Bred uranium from these reactors would have a high fissile content. It could be blended with thorlum and burned within the center or denatured and burned at dispersed reactors. The fuel fabrication plant for LEU fuel elements and for denatured fuel elements could be located either inside or outside the center since the fissile material used in this fuel could not be converted for use in explosive devices by chemical separation techniques.

Process flow sheets for LWR fuel reprocessing are shown in Ref. 14. The separation of uranium, plutonium and thorium occurs in the solvent extraction process. The plutonium containing partition column is highly purified and concentrated. Uranium bred in denatured fuel would contain a large ${ }^{238} \mathrm{U}$ component as would uranium discharged from LEU fuel. However, the uranium bred from $\mathrm{PuO}_{2} / \mathrm{ThO}_{2}$ fuel would be highly.fissile as would uranium discharged from fully enriched ${ }^{235} \mathrm{UO}_{2} / \mathrm{ThO}_{2}$ fuel. The ${ }^{232} \mathrm{U}$ component of the bred ${ }^{233} \mathrm{U}$ stream offers some safeguard advantages after a sufficient time interval has allowed buildup of radioactive ${ }^{232} \mathrm{U}$ 
daughter nuclides. The very low fissile content of the waste streams is judged to present no safeguards or proliferation concerns since the fissile material will have been removed to the limit of available technology. Entrainment of fissile material in the off gas treatment steps is judged insufficient to result in safeguards or proliferation concerns. However, accidental or intentional diversion of purified fissile material via a waste stream is a distinct possibility. 13

Figure 5.4 shows the steps for LWR fuel element fabrication. The uranium or plutonium is blended with thorium in the initial step; the chemical composition of the fuel remains the same through all remaining steps. The fuels containing plutonium as well as those containing uranium of a high fissile content blended with thorium will present a security problem since the high fissile content could be separated by chemical means. This would not be a problem for LEU fuel or denatured fuel. Fabrication of these fuels could possibly be performed outside the fuel cycle center. All reprocessing and refabrication steps could be carried out within the same physical facility if this were required in order to aid in security methods. 15

The next scenario involves the introduction of the LMFBR. Within the secured area LMFBRs with plutonium-thorium cores and thorium blankets would be utilized for ${ }^{233} \mathrm{U}$ production. Some LMFBRs within the secured area could have plutonium-uranium cores and thorium blankets if it were desirable to breed some additional plutonium to be burned within the secured area for ${ }^{23}{ }^{3} \mathrm{U}$ production. Denatured LMFBRs could be located at dispersed sites. 


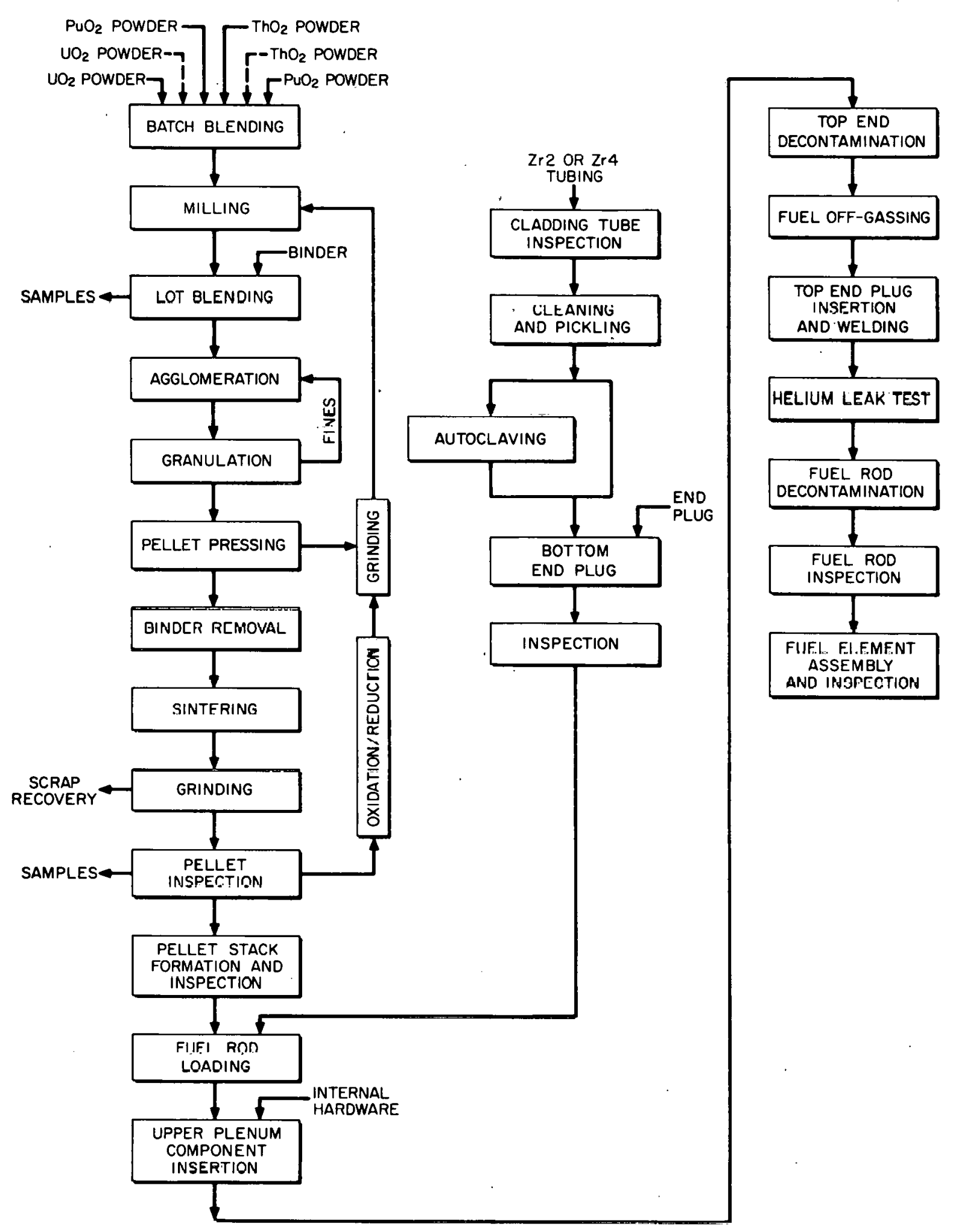

Fig. 5.4. LWR oxide fuel element fabrication. 
The flow sheets for LMFBR fuel reprocessing are shown in Ref. 14. In the solvent extraction step, both the ${ }^{23} \mathrm{U}$ and the plutonium streams from the partition columns would be highly purified and concentrated. As in the reprocessing of LWR fuel, entrainment of fissile material in the off gas treatment is insufficient to cause safeguards or proliferation concerns. Accidental or intentional diversion of purified or fissile material via waste streams is, however, a distinct possibility. 13

The flow sheets for'FBR fuel fabrication are given in Fig. 5.5. Blanket rod fabrication presents no safeguard or proliferation concerns. Except for denatured LMFBR fuel, highly fissile material is handled throughout the fuel element fabrication process and could be converted to material useable in an explosive device by chemical separation techniques.

The final scenario involves the introduction of HTGRs and HWRs. At the dispersed sites these reactors would utilize denatured or LEU fuel. In addition, the HWR could utilize natural uranium fuel. The plutoniumthorium HTGR could be utilized within the secured area as a plutonium burner. The reprocessing and refabrication steps for the HWR do not differ significanlly frum thuse already presented for the LWR. The fabrication flow sheets for HTGR fuel have been presented in Fig. 5.2. Except for denatured and LEU HTGR fuel, highly fissile material is handled throughout the fabrication process.

Reference 14 shows the reprocessing steps for HTGR fuel. Due to the nature of HTGR fuel elements and particles, the fissile material is physically separable from the fertile material. However, this should not cause safeguards concern in the head end process because the 


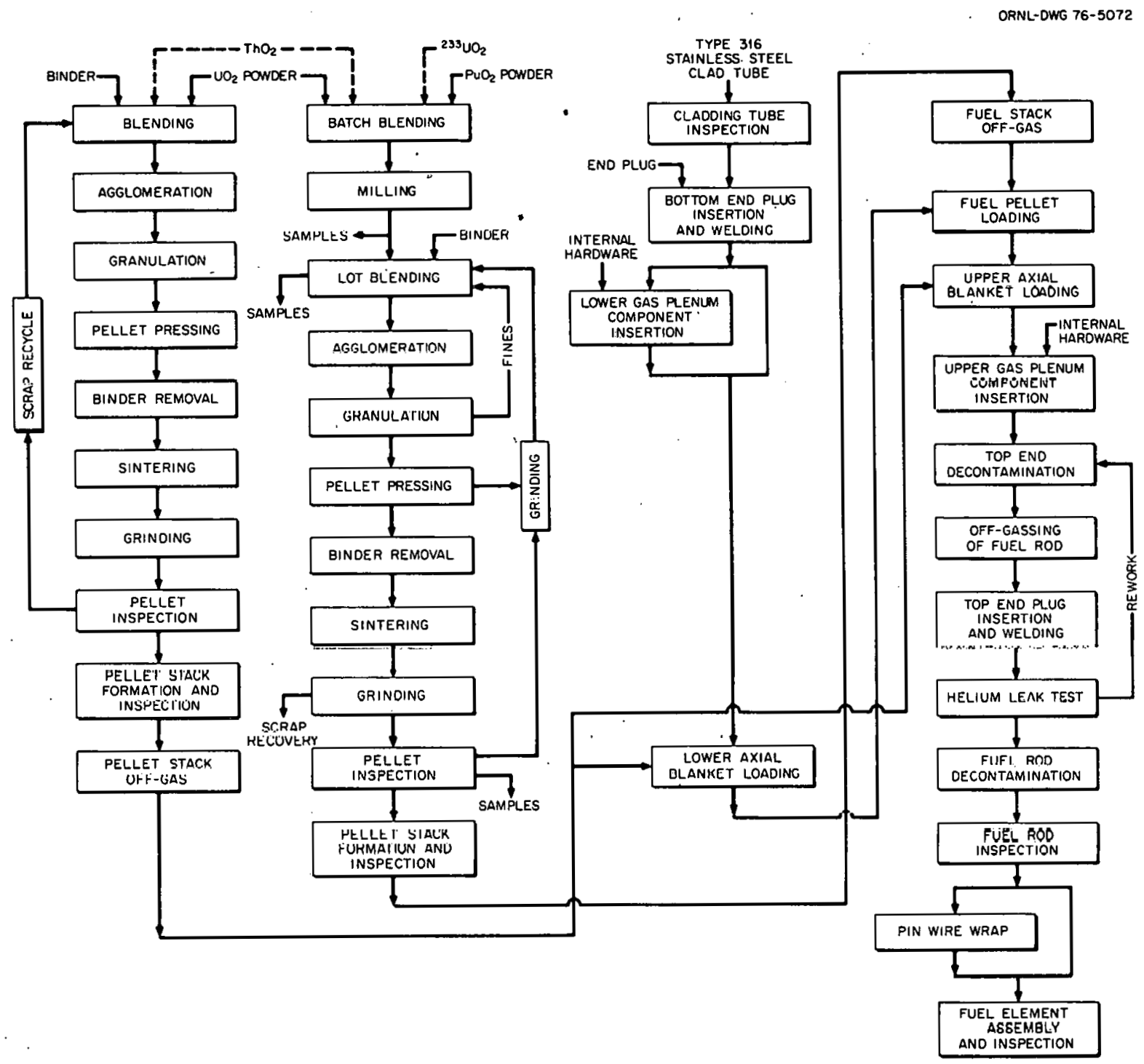

Fig. 5.5. FBR oxide fuel element fabrication. 
irradiated fuel is highly radioactive. Furthermore, a different particle design involving the same particle size and coating for fissile and fertile particles could preclude diversion by physical separation in the head end process. ${ }^{13}$ As in the reprocessing of LWR and LMFBR fuel, the solvent extraction step produces separate uranium and plutonium streams which are highly purified and concentrated. Entrainment of fissile material in off gas treatment is judged to be sufficiently small as to result in no safeguards concerns. Also, as in the reprocessing of other reactor fuel types, accidental or intentional diversion of purified fissile material via waste streams is a distinct safeguards concern.13 
REFERENCES

1. Thorium Assessment Study Quarterly Progress Report for First Quarter Fiscal 1977, ORNL/TM-5818.

2. Letter from Edouard Kufawski, Fast Breeder Reactor Department, General Electric, to Members of the Large Core Code Evaluation Working Group, SUBJECT: Transmittal of Design for Use in Large Core Code Evaluation, January 29, 1976.

3. D. R. Hoffner et al, "Summary of* Uniform Data Base for NRA Energy Systems Studies," Hanford Engineering Development Laboratory, June 7, 1977 .

4. T. J. Burns and D. E. Bartine, "Feasibility of Denatured LMFBRs," Trans. Am. Nucl. Soc., 26, 285 (1977).

5. R. L. Macklin and J. Halperin, $: 232 \mathrm{Th}(\mathrm{n}, \gamma)$ Cross Section from 2.6$800 \mathrm{keV}, "$ Nucl. Sci. Eng. (to be published).

6. J. A. Horak, J. H. Killel, and H. V. Rhude, "The Effects of Irradiation on Some Binary Alloys of Thorium-Plutonium and Z1rconfumPlutonlum," ANL 6428, Argonne Nationàl Läboracory, July 1962.

7. J. A. Horak, W. F. Murphy and S. H. Paine, "Effects of Irradiation on Thorium and Thorium Uranium Alloys," ANL 5674, Argonne National Laboratory, April 1963.

8. C. E. Dickerman, L. E. Robinson, B. Blumenthal and R. Stewart, "Behav10 of Th-20 wt $\%$ U Futl-Rgaclur Futl Uader Tidisient lleating to Failure," Nuclear Applications Vo1. 3, January 1967.

9. G. L. Copeland, "Evaluation of Thorium-Uranium Alloys for the Unclad Metal Breeder Reactor," ORNL 4557, Oak Ridge National Laboratory, June 1970 . 
10. B. Blumenthal, J. E. Sanecki, D. E. Busch and D. R. O'Bayle, "Thorium-Uranium-Plutonium Alloys as Potential Fast Power-Reactor Fuels (Part II. Properties and Irradiation Behavior of ThoriumUranium-Plutonium Alloys)," ANL-7259, Argonne National Laboratory, October 1969.

11. Thorium Assessment Study Quarter1y Progress Report for First Quarter Fiscal 1977, ORNL/TM-5818 (March 1977).

12. Letter, Dick Lane, Fuel Managment Services Branch, General Atomic Co. to P. R. Kasten, Director, Gas-Cooled Reactor Programs, ORNL, SUBJECT: Mass Balances for Throwaway HTGR, February 22, 1977.

13. Letter, P. R. Kasten, Director, Gas-Cooled Reactor Programs, ORNL to W. S. Scheib, Division of Nuclear Fuel Cycle and Production, ERDA, SUBJECT: Thorium Fuel Cycles and Nonproliferation, March 25, 1977.

14. P. R. Kasten et a1., Assessment of the Thorium Fuel Cycle in Power Reactors, ORNL/TM-5565, January 1977.

15. Private Communication, L. W. Carter, ORNL, to J. C. Cleveland, ORNL, April 19, 1977. 
THIS PAGE

\section{WAS INTENTIONALLY LEFT BLANK}




\section{Internal Distribution}

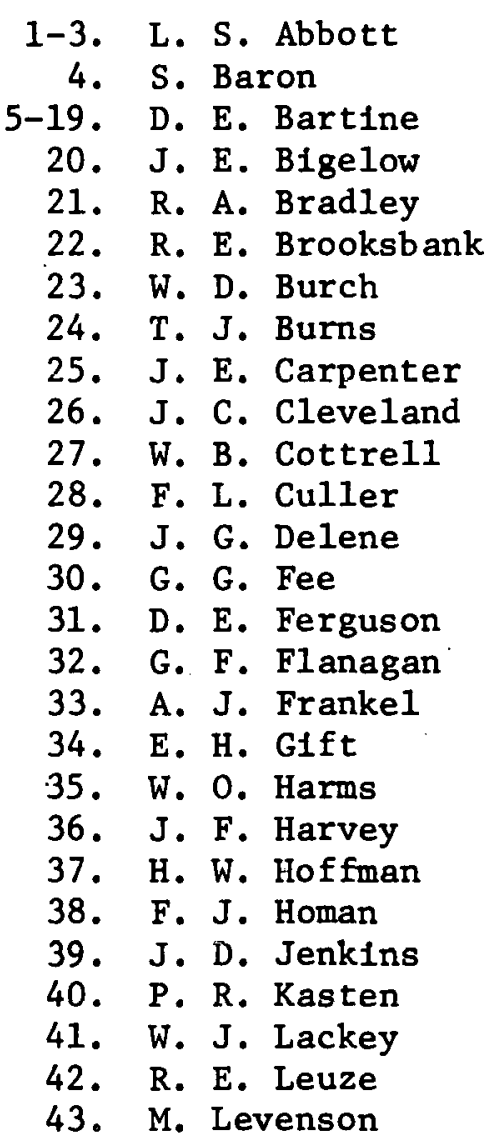

44. A. L. Lotts

45. F. C. Maienschein

46. R. E. MacPherson

47. F. R. Mynatt

48. K. J. Notz

49. H. Postma

50. J. E. Rushton

51. T. F. Scanlan

52. M. J. Skinner

53-54. I. Spiewak

55. W. E. Thomas

56. D. B. Trauger

57. W. E. Unger

58. B. L. Vondra

59. C. R. Weisbin

60. J. R. White

61. G. D. Whitman

62. R. P. Wichner

63-64. Central Research Library

65. Document Reference Section

66-68. Laboratory Records Dept.

69. Laboratory Records, RC

\section{External Distribution}

70-71. Director, Division of Nuclear Research and Applications, ERDA, Washington, D. C. 20545

72. Assistant Director for Energy Systems Analysis, DNRA, ERDA, Washington, D. C. 20545

73. K. A. Trickett, DNRA, ERDA, Washington, D. C. 20545

74. E. G. DeLaney, DNRA, ERDA, Washington, D. C. 20545

75. A. P. D'Zmura, DNRA, ERDA, Washington, D. C. 20545

76. D. Erb, DNRA, ERDA, Washington, D. C. 20545

77. N. Goldenberg, DNRA, ERDA, Washington, D. C. 20545

78. G. Newby, DNRA, ERDA, Washington, D. C. 20545

79. W. F. Savage, DNRA, ERDA, Washington, D. C. 20545

80. C. Sege, DNRA, ERDA, Washington, D. C. 20545

81. M. Wiener, DNRA, ERDA, Washington, D. C. 20545

82. W. S. Scheib, Jr., Division of Nuclear Fuel Cycle and Production, ERDA, Washington, D. C. 20545

83. Director, Reactor Division, ERDA, OR

84. Research and Technical Support Division, ERDA, OR

85. D. Linz, ERDA, OR 
External Distribution

$$
\text { contd. }
$$

86. Henry Bermanis, United Engineers \& Constructors, Inc., 30 South 17th Street, PhIladelphia, Pa. 19101

87. C. E. Til1, Applied Physics, Argonne National Laboratory, 9700 South Cass Avenue, Argonne, I11. 60439

88. Eugene Critoph, Head, Physics Branch, Chalk River Nuclear Laboratorles, Atomic Energy of Canada, Ltd., Chalk R1ver, Ontario, Canada KoJ 1Jo

89. M. J. Driscoll, Massachusetts Institute of Technology, 138 Albany Street, Cambridge, Mass. 02138

90. J. F. Foran, Resource Planning Assoctates, Inc., 44 Brattle Street, Cambridge, Mass. 02138

91. C. M. Newstead, Brookhaven National Laboratory, Technical Support nrganization, B1dg. 197, Uptüin, New Yurk 11973

92. R. P. Omberg, Manager, Advanced Concepts, Hanford Engineerting Uévelopment Laboratory, P. O. Box 1970, R1chland, Wash. 99352

93. Liberty Pease, Power Projects, Sheridan Park Research Community, Mississauga, Ontario 15K 1B2 Canada

94. A. Kadkowsky, Tel-Aviv University, School of Engineering, Ramat-Aviv, Tel Aviv, Israel 69970

95. Bal Raf Sehgal, Nuclear Safety \& Analysis Department, Electric Power Research Institute, 3412 Hillview Avenue, P. 0. Box 10412, Palo Alto, Calif. 94304

98. N. L. Shapiro, Manager, Advanced Design Projects, C-E Power Systems, Combustion Englneering, Inc., 1000 Prospect Hill Ruad, Windsór, Connecticut 06095

97. H. E. Williamson, Manager, Systems Analysis, Nuclear Englneering Operational Planning, General Electric Company, 175 Curtner Avenue, San Jose, California 95125

98. Lowell L. Wood, University of California, Lawrence Livermore Laboratory, P. 0. Box 808, LIvermore, California 94550

99-125. Technical Information Center, OR 